\title{
The Most Cited Articles from the Top-5 Journals (1991-2015)*
}

\author{
Laurent Linnemer ${ }^{\dagger}$ and Michael Visser ${ }^{\ddagger}$
}

August 23, 2016

\begin{abstract}
This paper documents what are the most cited articles published in the top- 5 economics journals during the period 1991-2015. EconLit is used to collect bibliographic information about these articles, and we gathered yearly citations for each article through the Web of Science database. We present different sorts of citation lists. Our most basic one ranks articles on the basis of the cumulated number of citations received between year of publication and 2015. To facilitate the comparison of articles of different ages, we also consider rankings by subperiods, and on the basis of normalized citations per year. Finally we report lists by field of economic research, as defined by the JEL codes of the articles. The paper contains Internet links to all articles, allowing an easy and direct access to arguably the most influential economics literature published in the last 25 years.
\end{abstract}

JEL codes: A14

${ }^{*}$ We thank Pol Antràs, Alan Taylor, and Eric Verhoogen for helpul comments.

${ }^{\dagger}$ CREST (ENSAE). Email: laurent.linnemer@ensae.fr.

${ }^{\ddagger}$ CREST (ENSAE) and CRED-University of Paris 2. Email: michael.visser@ensae.fr. 


\section{Introduction}

What are the most influential economics articles in the recent economics literature? And what are the articles that have attracted the most attention by field of economic research (labor, IO, econometrics, trade, etc.)? To answer these questions, we have collected bibliographic information on all articles published between 1991 and 2015 in the top-5 economics journals (AER, ECMA, JPE, QJE, and RESTUD). To measure the academic influence of these articles, we have also retrieved yearly citations for each of them. We use this database to document many different types of rankings. We shall comment the results only briefly, and let instead readers appreciate and go through our different lists by themselves.

This paper contributes to a recent literature wherein academic articles are ranked according to the number of citations they received. Van Noorden, Maher, Nuzzo, et al. (2014), for instance, list the 100 most highly cited papers of all time. This list covers all fields of research and is produced by consulting Thomson Reuter's Web of Science data base. There are also studies that rank academic output by subfields of research. Ryan and Woodall (2005), for example, identify the 25 most-cited statistical papers. Kim, Morse, and Zingales (2006) produce a list of economics articles that have received more than 500 citations. These two papers also retrieved the citation counts from the Web of Science database. A common feature of the studies in this literature is that they only rank articles on the basis of cumulated citations gathered between the year of publication and some instant (typically the date at which citations are collected). The disadvantage of such rankings is that old articles (with a long time span to gather citations) are favored relatively to recent ones (short time to collect citations). To account for the effects of age we therefore provide lists by sub-periods (in addition to our basic list based on cumulated citations). ${ }^{1}$ To establish these lists by sub-periods we exploit an unusual aspect of our data set, namely that citations are observed for each article on a yearly basis. We also compare articles on the basis of normalized number of citations (defined as the number of cumulated citations of an article divided by the average number of cumulated citations received by all other articles published in the same year). It turns out to be important to account for the effects of age: our lists that control for differences in publication years contain many recent articles that do not appear in the basic list because of unfair competition with articles from older cohorts.

All our rankings contain direct web links to the articles (clicking on them gives access to the pdf files), ${ }^{2}$ allowing for easy and direct access to a highly selective set of prominent economics papers. As such, this paper can be useful for researchers wishing to read relatively new articles that have the potential of becoming or already are classics in the literature. Our paper may also be helpful in guiding starting $\mathrm{PhD}$ students on what they should read to get a good picture of what is important in their chosen domain of research.

\section{Methodology and data}

Our data set is constructed by combining two sources. First, we used EconLit ${ }^{3}$ to collect bibliographic information about articles published in the top-5 economics journals between 1991 and 2015. We kept all articles published in this period except the ones that appeared in AER Papers and Proceedings, the comments on previously published papers (and replies to comments), ${ }^{4}$ corrections on articles, editorial statements, and all sorts of other announcements. Second, we gathered citation statistics on all these articles using the Web of Science database (hereafter $W o S$ ). For each top-5 article we thus observe the yearly number of citations (between the publication year and the end of 2015), in any of the academic journals referenced in the WoS.

\footnotetext{
${ }^{1}$ For example, we rank the articles published in the sub-period 1996-2000 on the basis of cumulated citations received within a time interval that is the same for all articles (15 years in this example)

${ }^{2}$ Direct consultation of the articles requires, however, a subscription to JSTOR (otherwise the links only give access to the abstracts and titles of the papers).

${ }^{3}$ We used the AEA member access which appeared to be the most convenient way.

${ }^{4}$ Comments (and replies) can be interesting but they are different in nature from standard articles. They are also much shorter and generally less cited so including them would bias the results for the journals that tend to publish them (primarily AER).
} 
Since all academic fields are covered in the $W o S$, our measure of citations refers to citations not just in economics journals but in journals of any field. We then merged the information obtained through EconLit and $W o S$ by matching on the author names and titles of the articles. ${ }^{5}$ Our final database contains 6,816 articles. ${ }^{6}$

Our goal is to provide lists of articles with the largest number of citations in $W o S$. This is also the objective in the paper by Kim, Morse, and Zingales (2006) who look at the 146 articles (published in 41 journals) that have received more than 500 citations in $W o S$ between the publication year and June 2006. One difference with their work is that we have all articles but in a narrower set of journals (in their list of 146 articles about $2 / 3$ are from the top-5). More crucially, we do not only report a list on the basis of the cumulated number of citations received between year of publication and the end of the observation period, but also rank articles by sub-periods and on the basis of normalized citations. These additional lists account for the age effects of articles (the fact that older articles are advantaged relatively to recent ones). To produce them we exploit the fact that we observe yearly citation counts (and not just the cumulated counts as in Kim et al.). Finally we give rankings by fields of economic research as defined by the JEL codes. $^{7}$

Table 1 reports the number of published articles in each of the five journals, separately for the whole observation period and for 5 sub-periods of 5 years each. Publications in the AER and ECMA are decomposed into regular (r) and short (s) publications. ${ }^{8}$ About 33\% of our total of 6,816 articles have been published in AER, $21 \%$ in ECMA, $15 \%$ in JPE, $15 \%$ in QJE, and $16 \%$ in RESTUD. The total production is relatively evenly distributed across the five sub-periods: 1,408 in the period 1991-1995, 1,196 in 1996-2000, 1,413 in 20012005, 1,337 in 2006-2010, and 1,462 in 2011-2015. These aggregate figures hide that AER has augmented its number of publications during the observation period (from 29\% of all publications in 1991-1995 to $40 \%$ in 2011-2015), while JPE and QJE have decreased their publications (from 17 to 10\% for JPE, and from 17 to $13 \%$ for QJE). The fraction of publication published in ECMA and RESTUD has remained relatively stable.

\section{Citations cumulated at the end of 2015}

In this section we give the list of most cited articles according to the cumulated number of citations between the publication year and the end of 2015. This is a crude but natural way to look at citations (at least as a first benchmark analysis). The obvious drawback with this analysis is that younger articles have had less time to accumulate citations than older ones. The distributions of the cumulated citations are summarized in Table 2 for each journal.

Several quick remarks can be made. First, the articles in our sample have received many citations: about 84 on average and a median equal to 36. At the very top, the 69 articles in the last percentile have each at least 734 citations. Second, the average and all percentiles of QJE articles are higher than those of articles published in the four other journals. Third, RESTUD published the article with the highest number of citations. Fourth, AER (s) and ECMA (s) are comparable to RESTUD. In fact, articles in AER (s) have even more citations (on average) than articles in RESTUD and the difference is significantly different from zero.

\footnotetext{
${ }^{5}$ For about $95 \%$ of the articles the matching was immediate, for the remaining $5 \%$ we had to check manually because of small spelling mistakes.

${ }^{6}$ Some articles published in 2015 are missing (basically the last issue of all journals) because the EconLit database was not yet completed by the Spring of 2016. So about 36 articles are missing. For our purpose here it is not an issue as these last articles of 2015 could not possibly have many citations.

${ }^{7} \mathrm{~A}$ related literature studies the determinants of citations of economics articles in top- 5 journals. Card and DellaVigna (2013), Hamermesh (2013) and Anauati, Galiani, and Gálvez (2016) are based on slightly longer observation periods compared to our's. Card and DellaVigna and Anauati, Galiani, and Gálvez study all articles that appeared during 1970-2012 and 19702000, respectively. The analysis of Hamermesh covers the period 1963-2011, but his sample only contains six publication years (one year per decade). These articles do not, however, contain lists of the most cited articles.

${ }^{8}$ Short publications refer to the 'Shorter papers' in AER and the 'Notes and comments' in ECMA.
} 
Table 1: Number of articles per journal

\begin{tabular}{|c|c|c|c|c|c|c|}
\hline & All years & 91-95 & $96-00$ & 01-05 & 06-10 & $11-15$ \\
\hline $\begin{array}{l}\text { aer }(\mathrm{r}) \\
\text { aer }(\mathrm{s})\end{array}$ & $\begin{array}{l}1,555(100) \\
(22.8) \\
689(100) \\
(10.1) \\
\end{array}$ & $\begin{array}{l}281(18.1) \\
(20.0) \\
133(19.3) \\
(9.4)\end{array}$ & $\begin{array}{l}239(15.4) \\
(20.0) \\
95(13.8) \\
(7.9) \\
\end{array}$ & $\begin{array}{l}277(17.8) \\
(19.6) \\
166(24.1) \\
(11.7) \\
\end{array}$ & $\begin{array}{l}320(20.6) \\
(23.9) \\
144(20.9) \\
(10.8)\end{array}$ & $\begin{array}{l}438(28.2) \\
(30.0) \\
151(21.9) \\
(10.3)\end{array}$ \\
\hline aer (all) & $\begin{array}{l}2,244(100) \\
(32.9)\end{array}$ & $\begin{array}{l}414(18.4) \\
(29.4) \\
\end{array}$ & $\begin{array}{l}334(14.9) \\
(27.9) \\
\end{array}$ & $\begin{array}{l}443(19.7) \\
(31.4)\end{array}$ & $\begin{array}{l}464(20.7) \\
(34.7)\end{array}$ & $\begin{array}{l}589(26.2) \\
(40.3) \\
\end{array}$ \\
\hline $\begin{array}{l}\text { ecma (r) } \\
\text { ecma (s) }\end{array}$ & $\begin{array}{l}1,078(100) \\
(15.8) \\
351(100) \\
(5.1)\end{array}$ & $\begin{array}{l}236(21.9) \\
(16.8) \\
56(16.0) \\
(4.0)\end{array}$ & $\begin{array}{l}191(17.7) \\
(16.0) \\
55(15.7) \\
(4.6)\end{array}$ & $\begin{array}{l}230(21.3) \\
(16.3) \\
101(28.8) \\
(7.1) \\
\end{array}$ & $\begin{array}{l}193(17.9) \\
(14.4) \\
74(21.1) \\
(5.5) \\
\end{array}$ & $\begin{array}{l}228(21.2) \\
(15.6) \\
65(18.5) \\
(4.4) \\
\end{array}$ \\
\hline ecma (all) & $\begin{array}{l}1,429(100) \\
(21.0)\end{array}$ & $\begin{array}{l}292(20.4) \\
(20.7) \\
\end{array}$ & $\begin{array}{l}246(17.2) \\
(20.6)\end{array}$ & $\begin{array}{l}331(23.2) \\
(23.4) \\
\end{array}$ & $\begin{array}{l}267(18.7) \\
(20.0)\end{array}$ & $\begin{array}{l}293(20.5) \\
(20.0)\end{array}$ \\
\hline jpe & $\begin{array}{l}1,021(100) \\
(15.0)\end{array}$ & $\begin{array}{l}245(24.0) \\
(17.4)\end{array}$ & $\begin{array}{l}244(23.9) \\
(20.4)\end{array}$ & $\begin{array}{l}231(22.6) \\
(16.3)\end{array}$ & $\begin{array}{l}158(15.5) \\
(11.8)\end{array}$ & $\begin{array}{l}143(14.0) \\
(9.8)\end{array}$ \\
\hline qje & $\begin{array}{l}1,053(100) \\
(15.4)\end{array}$ & $\begin{array}{l}242(23.0) \\
(17.2)\end{array}$ & $\begin{array}{l}202(19.2) \\
(16.9)\end{array}$ & $\begin{array}{l}202(19.2) \\
(14.3)\end{array}$ & $\begin{array}{l}211(20.0) \\
(15.8)\end{array}$ & $\begin{array}{l}196(18.6) \\
(13.4)\end{array}$ \\
\hline restud & $\begin{array}{l}1,069(100) \\
(15.7)\end{array}$ & $\begin{array}{l}215(20.1) \\
(15.3) \\
\end{array}$ & $\begin{array}{l}170(15.9) \\
(14.2) \\
\end{array}$ & $\begin{array}{l}206(19.3) \\
(14.6) \\
\end{array}$ & $\begin{array}{l}237(22.2) \\
(17.7) \\
\end{array}$ & $\begin{array}{l}241(22.5) \\
(16.5) \\
\end{array}$ \\
\hline All & $\begin{array}{l}6,816(100) \\
(100)\end{array}$ & $\begin{array}{l}1408(20.7) \\
(100)\end{array}$ & $\begin{array}{l}1196(17.5) \\
(100)\end{array}$ & $\begin{array}{l}1413(20.7) \\
(100)\end{array}$ & $\begin{array}{l}1337(19.6) \\
(100)\end{array}$ & $\begin{array}{l}1462(21.4) \\
(100)\end{array}$ \\
\hline
\end{tabular}

Table 2: Cumulated citations at the end of 2015

\begin{tabular}{lrrrrrrrrrrrrr}
\hline \hline & $\mathrm{N}$ & mean & $\sigma$ & min & $\mathrm{p} 5$ & $\mathrm{p} 10$ & $\mathrm{p} 25$ & $\mathrm{p} 50$ & $\mathrm{p} 75$ & $\mathrm{p} 90$ & $\mathrm{p} 95$ & $\mathrm{p} 99$ & max \\
\hline aer (r) & 1,555 & 84.47 & 141.14 & 0 & 1 & 3 & 14 & 40 & 99 & 210 & 297 & 702 & 1,940 \\
aer (s) & 689 & 59.94 & 107.16 & 0 & 2 & 4 & 12 & 29 & 65 & 137 & 201 & 471 & 1,310 \\
\hline aer (all) & 2,244 & 76.94 & 132.11 & 0 & 1 & 3 & 13 & 36 & 86 & 185 & 283 & 646 & 1,940 \\
\hline ecma (r) & 1,078 & 89.07 & 180.26 & 0 & 1 & 4 & 14 & 38 & 91 & 200 & 312 & 886 & 2,252 \\
ecma (s) & 351 & 38.60 & 70.35 & 0 & 1 & 2 & 8 & 20 & 42 & 83 & 141 & 392 & 841 \\
\hline ecma (all) & 1,429 & 76.67 & 161.84 & 0 & 1 & 3 & 12 & 33 & 78 & 167 & 273 & 734 & 2,252 \\
\hline jpe & 1,021 & 94.15 & 180.45 & 0 & 2 & 6 & 18 & 45 & 108 & 215 & 316 & 728 & 3,362 \\
qje & 1,053 & 131.78 & 222.55 & 0 & 2 & 6 & 22 & 66 & 156 & 296 & 453 & 1,167 & 2,349 \\
restud & 1,069 & 53.80 & 157.81 & 0 & 1 & 3 & 8 & 22 & 55 & 112 & 174 & 445 & 4,285 \\
\hline All & 6,816 & 84.30 & 167.91 & 0 & 1 & 4 & 13 & 37 & 92 & 197 & 302 & 734 & 4,285 \\
\hline
\end{tabular}

We list the top $1 \%$ of the most cited articles in Table 3. For each article, one can access its JSTOR page by clicking on the title (in the pdf version of this report). The first column gives the rank of the article, the second one the total number of citations received between the publication year and the end of 2015, and the third column the title of the paper. ${ }^{9}$ The fourth column lists the name(s) of the author(s) (when there is only one or two coauthors, otherwise only the name of the first author is given), and the column indicates the journal and the publication year. The sixth column gives all the JEL codes of the article (aggregated at the one digit level), and the seventh column indicates the type of the article. Using the JEL codes, keywords, and in particular the abstracts we have (non-manually) classified articles into three types: Data, experiment, and theory. ${ }^{10}$ Finally, the eighth column gives the percentage of authors with a position in the

\footnotetext{
${ }^{9}$ For space limitations, only the first 50 characters are shown, or less if the title contains an interrogation mark or a colon.

${ }^{10}$ Hamermesh (2013) implements a finer typology with five types: theory, theory with simulation, empirical using borrowed data, empirical using self generated data, and experiment. He only had to classify 748 articles whereas our database contains
} 
USA ( 1 if all authors work in the USA, 0.5 if half of the authors are affiliated with a U.S. institution, etc.).

Table 3: Articles in the top $1 \%$ for $T=1991-2015$

\begin{tabular}{|c|c|c|c|c|c|c|c|}
\hline Rank & WoS & Title & Authors & Journal & JEL & Type & USA \\
\hline 1 & 4285 & Some Tests of Specification for Panel Data & Arellano ; Bond & restud-91 & $\mathrm{C} 2-\mathrm{J} 2$ & $\mathrm{D}$ & 0 \\
\hline 2 & 3362 & Law and Finance & La Porta et al. & jpe-98 & K2 & $\mathrm{D}$ & 1 \\
\hline 3 & 2349 & Economic Growth in a Cross Section of Countries & Barro & qje-91 & O4-O5 & $\mathrm{D}$ & 1 \\
\hline 4 & 2274 & A Theory of Fairness, Competition, and Cooperation & Fehr ; Schmidt & qje-99 & $\mathrm{D} 6-\mathrm{C} 7$ & $\mathrm{~T}$ & 0 \\
\hline 5 & 2252 & Estimation and Hypothesis Testing of Cointegration & Johansen & ecma-91 & $\mathrm{C} 3$ & $\mathrm{D}$ & 0 \\
\hline 6 & 2176 & Increasing Returns and Economic Geography & Krugman & jpe-91 & R1-R3 & $\mathrm{T}$ & 1 \\
\hline 7 & 2075 & A Contribution to the Empirics of Economic Growth & Mankiw et al. & q.je-92 & $\mathrm{O} 4$ & $\mathrm{D}$ & 1 \\
\hline 8 & 1940 & The Colonial Origins of Comparative Development & Acemoglu et al. & aer-01 & O1-I1 & $\mathrm{D}$ & 1 \\
\hline 9 & 1926 & Conditional Heteroskedasticity in Asset Returns & Nelson & ecma-91 & C5-G1 & $\mathrm{D}$ & 1 \\
\hline 10 & 1917 & Geographic Localization of Knowledge Spillovers as & Jaffe et al. & qje-93 & O3 & $\mathrm{D}$ & 0.67 \\
\hline 11 & 1850 & Instrumental Variables Regression with Weak Instru & Staiger ; Stock & ecma-97 & $\mathrm{C} 3$ & $\mathrm{D}$ & 1 \\
\hline 12 & 1774 & The Impact of Trade on Intra-industry Reallocation & Melitz & ecma-03 & $\mathrm{F} 1-\mathrm{F} 2$ & $\mathrm{~T}$ & 1 \\
\hline 13 & 1617 & Jhy Do Some Countries Produce So Much More Output & Hall ; Jones & q.je- & $\mathrm{O} 4-\mathrm{E} 2$ & $\mathrm{D}$ & 1 \\
\hline 14 & 1534 & A Sensitivity Analysis of Cross-Country Growth Reg & Levine ; Renelt & aer & $\mathrm{O} 4$ & $\mathrm{D}$ & 1 \\
\hline 15 & 1516 & Corruption and Growth & Mauro & qje- & D7 & $\mathrm{D}$ & 1 \\
\hline 16 & 1512 & A Model of Growth through Creative Destruction & Aghion ; Howitt & ecms & $\mathrm{O} 4-\mathrm{O} 3$ & $\mathrm{~T}$ & 0 \\
\hline 17 & 1489 & How Much Should We Trust Differences-in-Difference & Bertrand et al. & q.je- & $\mathrm{C} 2-\mathrm{J} 3$ & $\mathrm{D}$ & 1 \\
\hline 18 & 1430 & Efficient Tests for an Autoregressive Unit Root & Elliott et al. & ecma-96 & $\mathrm{C} 2-\mathrm{C} 5$ & $\mathrm{D}$ & 1 \\
\hline 19 & 1406 & Loss Aversion in Riskless Choice & Tversky ; Kahneman & q.je- & D1 & $\mathrm{E}$ & 1 \\
\hline 20 & 1374 & A Theory of Fads, Fashion, Custom, and Cultural Ch & Bikhchandani et al. & jpe & D7-D8 & $\mathrm{T}$ & 1 \\
\hline 21 & 1361 & Incorporating Fairness into Game Theory and Econom & Rabin & aer-93 & $\mathrm{C} 7-\mathrm{D} 6$ & $\mathrm{~T}$ & 1 \\
\hline 22 & 1340 & The Penn World Table (Mark 5) & Summers ; Heston & qje-91 & O5-E1 & $\mathrm{D}$ & 1 \\
\hline 23 & 1333 & Convergence & Barro ; Sala-i-Martin & jpe- & $\mathrm{O} 4-\mathrm{N} 1$ & $\mathrm{D}$ & 1 \\
\hline 24 & 1328 & Does Social Capital Have an Economic Payoff & Knack ; Keefer & q.je-97 & $\mathrm{O} 4-\mathrm{P} 1$ & $\mathrm{D}$ & 1 \\
\hline 25 & 1326 & $\mathrm{ERC}$ & Bolton ; Ockenfels & aer-00 & $\mathrm{D} 6-\mathrm{C} 7$ & $\mathrm{~T}$ & 0.50 \\
\hline 26 & 1310 & R\&D spillovers and the geography of innovation an & Audretsch ; Feldman & $\operatorname{aer}(\mathrm{s})-96$ & O3-R1 & $\mathrm{D}$ & 0.50 \\
\hline 27 & 1263 & Heteroskedasticity and Autocorrelation Consistent & Andrews & ecma-91 & $\mathrm{C} 2$ & $\mathrm{D}$ & 1 \\
\hline 28 & 1221 & Growth in Cities & Glaeser et al. & jpe-92 & $\mathrm{R} 1-\mathrm{O} 4$ & $\mathrm{D}$ & 0.25 \\
\hline 29 & 1214 & Financial Dependence and Growth & Rajan ; Zingales & aer-98 & $\mathrm{E} 4-\mathrm{G} 2$ & $\mathrm{D}$ & 1 \\
\hline 30 & 1167 & Corporate Governance and Equity Prices & Gompers et al. & qje-03 & G1-G3 & $\mathrm{D}$ & 1 \\
\hline 31 & 1163 & A Simple Model of Herd Behavior & Banerjee & qje-92 & D8-D6 & $\mathrm{T}$ & 1 \\
\hline 32 & 1142 & olden Eggs and Hyperbolic Discounting & Laibson & qje-97 & D9-G1 & $\mathrm{D}$ & 1 \\
\hline 33 & 1138 & Identification of Endogenous Social Effects & Manski & restud-93 & $\mathrm{C} 2$ & $\mathrm{D}$ & 1 \\
\hline 34 & 1137 & Estimating and Testing Linear Models with Multiple & Bai ; Perron & ecma-98 & $\mathrm{C} 2$ & $\mathrm{D}$ & 0.50 \\
\hline 35 & 1101 & Africa's Growth Tragedy & Easterly ; Levine & q.je-97 & O5-J1 & $\mathrm{D}$ & 1 \\
\hline 36 & 1090 & Tests for Parameter Instability and Structural Cha & Andrews & ecma-93 & $\mathrm{C} 2$ & $\mathrm{D}$ & 1 \\
\hline 37 & 1084 & Changes in Relative Wages, 1963-1987 & Katz ; Murphy & qje-92 & J3 & $\mathrm{D}$ & 1 \\
\hline 38 & 1081 & Protection for Sale & Grossman ; Helpman & aer-94 & F1-D7 & $\mathrm{T}$ & 0.50 \\
\hline 39 & 1054 & Gravity with Gravitas & Anderson ; van Wincoop & aer-03 & F1 & $\mathrm{D}$ & 1 \\
\hline 40 & 1047 & ominal Rigidities and the Dynamic Effects of a Sh & Christiano et al. & jpe-05 & E1-E3 & $\mathrm{T}$ & 1 \\
\hline 41 & 1032 & Cooperation and Punishment in Public Goods Experim & Fehr ; Gachter & $\operatorname{aer}(\mathrm{s})-00$ & $\mathrm{H} 4$ & $\mathrm{E}$ & 0 \\
\hline 42 & 1029 & Finance and Growth & King ; Levine & qje-93 & O1 & $\mathrm{D}$ & 1 \\
\hline 43 & 1023 & conomic Growth and the Environment & Grossman ; Kruege & qje-95 & O4-Q2 & $\mathrm{D}$ & 1 \\
\hline 44 & 1016 & Monetary Policy Rules and Macroeconomic Stability & Clarida et al. & qje-00 & E5 & $\mathrm{D}$ & 0.83 \\
\hline 45 & 978 & Credit Cycles & Kiyotaki ; Moore & jpe-97 & $\mathrm{E} 5-\mathrm{E} 3-\mathrm{E} 2$ & $\mathrm{~T}$ & 0.50 \\
\hline 46 & 968 & Matching as an Econometric Evaluation Estimator & Heckman et al. & restud-97 & $\mathrm{J} 2-\mathrm{C} 5$ & $\mathrm{D}$ & 1 \\
\hline 47 & 964 & Risk Aversion and Incentive Effects & Holt ; Laury & $\operatorname{aer}(\mathrm{s})-02$ & D8-D1 & $\mathrm{E}$ & 1 \\
\hline 48 & 948 & Does Trade Cause Growth & Frankel ; Romer & aer-99 & $\mathrm{F} 4-\mathrm{O} 4$ & $\mathrm{D}$ & 1 \\
\hline 49 & 915 & Automobile Prices in Market Equilibrium & Berry et al. & ecma-95 & L1-L6 & $\mathrm{D}$ & 1 \\
\hline 50 & 912 & Corruption & Shleifer ; Vishny & q.je-93 & $\mathrm{D} 7-\mathrm{K} 4$ & $\mathrm{~T}$ & 1 \\
\hline 51 & 909 & Productivity Growth, Technical Pro & Fare et al. & aer-94 & $\mathrm{O} 4$ & $\mathrm{D}$ & 0.25 \\
\hline 52 & 886 & A Simple Estimator of Cointegrating Vectors in Hig & Stock ; Watson & ecma-93 & $\mathrm{C} 3-\mathrm{E} 4$ & $\mathrm{D}$ & 1 \\
\hline 53 & 875 & Lag Length Selection and the Construction of Unit & $\mathrm{Ng}$; Perron & ecma-01 & $\mathrm{C} 2$ & $\mathrm{D}$ & 1 \\
\hline 54 & 872 & By Force of Habit & Campbell ; Cochrane & jpe-99 & G1 & $\mathrm{T}$ & 1 \\
\hline
\end{tabular}

6,816 articles. Another manual classification has been done by Anauati, Galiani, and Gálvez (2016). They classified the articles into 4 research fields (applied, applied theory, econometric methods, and theory). As our classification is non manual, it is not perfect. 


\begin{tabular}{|c|c|c|c|c|c|c|c|}
\hline Rank & WoS & Title & Authors & Journal & JEL & Type & USA \\
\hline 55 & 841 & Identification and Estimation of Local Average Tre & Imbens ; Angrist & ecma(s)-94 & C5 & $\mathrm{D}$ & 0.50 \\
\hline 56 & 820 & Income Distribution and Macroeconomics & Galor ; Zeira & restud-93 & E2-E1 & $\mathrm{T}$ & 0.50 \\
\hline 57 & 817 & The Effects of Human Resource Management Practices & Ichniowski et al. & aer-97 & J2-L6 & $\mathrm{D}$ & 1 \\
\hline 57 & 817 & Distributive Politics and Economic Growth & Alesina ; Rodrik & q.je-94 & O4-D7 & $\mathrm{D}$ & 1 \\
\hline 59 & 807 & The Twin Crises & Kaminsky ; Reinhart & aer-99 & F3-F3 & $\mathrm{D}$ & 1 \\
\hline 60 & 779 & Learning, Mutation, and Long Run Equilibria in Gam & Kandori et al. & ecma-93 & $\mathrm{C} 7-\mathrm{D} 8$ & $\mathrm{~T}$ & 0.67 \\
\hline 61 & 774 & Long-Run Policy Analysis and Long-Run Growth & Rebelo & jpe-91 & O4-E6 & $\mathrm{T}$ & 0.67 \\
\hline 62 & 755 & Understanding Social Preferences with Simple Tests & Charness ; Rabin & qje-02 & $\mathrm{D} 7$ & $\mathrm{E}$ & 1 \\
\hline 63 & 752 & Economics and Identity & Akerlof ; Kranton & q.je-00 & D1-J1 & $\mathrm{T}$ & 1 \\
\hline 64 & 746 & Stock Markets, Banks, and Economic Growth & Levine ; Zervos & aer-98 & E4-G1 & $\mathrm{D}$ & 0.50 \\
\hline 65 & 743 & Reversal of Fortune & Acemoglu et al. & qje-02 & D3-O1 & $\mathrm{D}$ & 1 \\
\hline 65 & 743 & Is Inequality Harmful for Growth & Persson ; Tabellini & aer-94 & O4-D3 & $\mathrm{D}$ & 0 \\
\hline 67 & 738 & Do Domestic Firms Benefit from Direct Foreign Inve & Aitken ; Harrison & aer-99 & $\mathrm{O} 1-\mathrm{F} 2$ & $\mathrm{D}$ & 1 \\
\hline 68 & 734 & Transform Analysis and Asset Pricing for Affine Ju & Duffie et al. & ecma-00 & G1 & $\mathrm{T}$ & 1 \\
\hline 68 & 734 & Wage Inequality and the Rise in Returns to Skill & Juhn et al. & jpe-93 & J3 & $\mathrm{D}$ & 1 \\
\hline 70 & 733 & Export versus FDI with Heterogeneous Firms & Helpman et al. & $\operatorname{aer}(\mathrm{s})-04$ & F1-F2 & $\mathrm{D}$ & 0.83 \\
\hline
\end{tabular}

The top- $1 \%$ list is made up of 70 articles. At the very top the distribution of citations is very skewed as these articles count for $15.6 \%$ of all citations in our sample. On average, an article in the list has 1,280 citations. The most cited article is (by far) "Some Tests of Specification for Panel Data: Monte Carlo Evidence and an Application to Employment Equations" by Manuel Arellano and Stephen Bond with 4,285 citations (923 more citations than the second one, or 27\% more). It was published in RESTUD in 1991 and at that time both authors were working in the U.K.: Arellano at the LSE and Bond at Oxford university. In a sense, this article is atypical first because it is published in RESTUD (only 4 articles in the list are published by this journal), and second because both its authors were affiliated with institutions outside the U.S. (as the last column of the table shows most articles are written at least in part by U.S. based economists).

Among the 70 articles, 18 are published in the AER (including 4 short articles), 15 in ECMA (including 1 short article), 10 in JPE, 23 in QJE, and 4 in RESTUD. This clearly illustrates the dominant position of QJE discussed earlier. Given the citation measure chosen here, it does not come as a surprise that many articles in the list are rather old. Half of them have been published in the period 91-95, 24 in 90-00, and 11 in 01-05. The most recent paper is "Nominal Rigidities and the Dynamic Effects of a Shock to Monetary Policy" by Lawrence J. Christiano, Martin Eichenbaum and Charles L. Evans, published in JPE in 2005. It is ranked 40th with already 1,047 citations cumulated over 10 years.

Clearly the field growth/trade is over-represented in this list as the word "growth" appears in 16 of the 70 titles $(23 \%)$. There are also relatively many articles that have at least one "C" among their JEL codes (13, or 18.6\%). Relatively many articles are thus based on mathematical or quantitative methods. The other articles are split evenly among the other fields (as defined by the JEL codes). Looking at the column describing the type of article, it is also apparent that a majority of the articles in the list are data-oriented: either because their contribution is in the field of econometrics (with or without empirical application), or because their goal is primarily empirical (analysis of a dataset). Theoretical papers are relatively rare, only 18 fall into this category (26\%). This contrasts with the full sample where $47 \%$ of the articles are classified theoretical. Admittedly, not all the articles that fall in this category are theoretical in the usual sense. For example, the paper "Corruption" by Shleifer and Vishny, published in QJE in 1993, contains not more than a single equation. Finally, $81.7 \%$ of the authors of the top- $1 \%$ articles work in the USA, compared to $69.5 \%$ in the full sample. 


\section{Lists for five-year time periods}

A drawback of the analysis in the previous section is that by measuring influence via the cumulated number of citations, recent articles are disadvantaged compared to old ones. Comparing two articles, one published in say 1992 and the other in 2002 is unfair in the sense that the former has had 10 more years than the latter to accumulate citations. In this section we propose a more equitable and balanced analysis by comparing articles published in subperiods. We start by considering all articles published in the period 1991-1995, and take as our measure of influence of an article its cumulated number of citations obtained in the interval [year of publication, year of publication +20 ]. We then move on to the period 1996-2000, and rank articles on the basis of their total number of citations cumulated in the interval [year of publication, year of publication + 15]. We proceed like this until we reach the most recent period, 2011-2015, for which we establish a ranking based on cumulated citations in the interval [year of publication, year of publication +2 ]. As we analyze more recent periods, the time interval over which citations are counted gets shorter, but the important thing here is that all articles are treated equally.

\section{$4.1 \quad 1991-1995$}

Between 1991 and 1995 a total of 1,424 articles have been published. Table 4 lists the 50 most cited articles for this period of time. The table is organized as Table 3 except that the second column now gives the cumulated number of citations gathered by each article between its publication year and 20 years thereafter (denoted $C_{i}(20)$ ). There is overlap between this listing and the one reported in the previous section. For instance, the article by Arellano and Bond remains at the top. Furthermore, all the first 25 articles of Table 4 appear in Table 3 as well. However, the second half of Table 4 contains many articles that are not inluded in Table 3. Many of these articles are published in either 1994 or 1995 (for example, the paper "Globalization and the Inequality of Nations" by Krugman and Venables, published in QJE in 1995), illustrating the point made at the beginning of this section, namely that rankings based on cumulated citations as reported in the previous section may disadvantage relatively recent papers.

Table 4: Top 50 articles for $T=1991-1995$

\begin{tabular}{|c|c|c|c|c|c|c|c|}
\hline Rank & $C_{i}(20)$ & Title & Authors & Journal & JEL & Type & USA \\
\hline 1 & 2225 & Some Tests of Specification for Panel Data & Arellano ; Bond & restud-91 & $\mathrm{C} 2-\mathrm{J} 2$ & $\mathrm{D}$ & 0 \\
\hline 2 & 1770 & Economic Growth in a Cross Section of Countries & Barro & qje-91 & $\mathrm{O} 4-\mathrm{O} 5$ & $\mathrm{D}$ & 1 \\
\hline 3 & 1711 & Estimation and Hypothesis Testing of Cointegration & Johansen & ecma-91 & $\mathrm{C} 3$ & $\mathrm{D}$ & 0 \\
\hline 4 & 1620 & A Contribution to the Empirics of Economic Growth & Mankiw et al. & qje-92 & O4 & $\mathrm{D}$ & 1 \\
\hline 5 & 1608 & Geographic Localization of Knowledge Spillovers as & Jaffe et al. & qje-93 & O3 & $\mathrm{D}$ & 0.67 \\
\hline 6 & 1516 & Corruption and Growth & Mauro & qje-95 & D7 & $\mathrm{D}$ & 1 \\
\hline 7 & 1506 & Increasing Returns and Economic Geography & Krugman & jpe-91 & R1-R3 & $\mathrm{T}$ & 1 \\
\hline 8 & 1319 & A Sensitivity Analysis of Cross-Country Growth Reg & Levine ; Renelt & aer-92 & $\mathrm{O} 4$ & $\mathrm{D}$ & 1 \\
\hline 9 & 1309 & Conditional Heteroskedasticity in Asset Returns & Nelson & ecma-91 & C5-G1 & $\mathrm{D}$ & 1 \\
\hline 10 & 1263 & The Penn World Table (Mark 5) & Summers ; Heston & qje-91 & O5-E1 & $\mathrm{D}$ & 1 \\
\hline 11 & 1157 & Incorporating Fairness into Game Theory and Econom & Rabin & aer-93 & C7-D6 & $\mathrm{T}$ & 1 \\
\hline 12 & 1145 & A Model of Growth through Creative Destruction & Aghion ; Howitt & ecma-92 & $\mathrm{O} 4-\mathrm{O} 3$ & $\mathrm{~T}$ & 0 \\
\hline 13 & 1082 & Convergence & Barro ; Sala-i-Martin & jpe-92 & $\mathrm{O} 4-\mathrm{N} 1$ & $\mathrm{D}$ & 1 \\
\hline 14 & 1023 & Economic Growth and the Environment & Grossman ; Krueger & qje-95 & $\mathrm{O} 4-\mathrm{Q} 2$ & $\mathrm{D}$ & 1 \\
\hline 15 & 1005 & A Theory of Fads, Fashion, Custom, and Cultural Ch & Bikhchandani et al. & jpe-92 & D7-D8 & $\mathrm{T}$ & 1 \\
\hline 16 & 1004 & Protection for Sale & Grossman ; Helpman & aer-94 & F1-D7 & $\mathrm{T}$ & 0.50 \\
\hline 17 & 955 & Heteroskedasticity and Autocorrelation Consistent & Andrews & ecma-91 & $\mathrm{C} 2$ & $\mathrm{D}$ & 1 \\
\hline 18 & 936 & Growth in Cities & Glaeser et al. & jpe-92 & $\mathrm{R} 1-\mathrm{O} 4$ & $\mathrm{D}$ & 0.25 \\
\hline 19 & 931 & Tests for Parameter Instability and Structural Cha & Andrews & ecma-93 & $\mathrm{C} 2$ & $\mathrm{D}$ & 1 \\
\hline 20 & 915 & Automobile Prices in Market Equilibrium & Berry et al. & ecma-95 & L1-L6 & $\mathrm{D}$ & 1 \\
\hline 20 & 915 & Changes in Relative Wages, 1963-1987 & Katz ; Murphy & qje-92 & J3 & $\mathrm{D}$ & 1 \\
\hline 22 & 906 & Loss Aversion in Riskless Choice & Tversky ; Kahneman & qje-91 & D1 & $\mathrm{E}$ & 1 \\
\hline 23 & 862 & Finance and Growth & King ; Levine & qje-93 & O1 & $\mathrm{D}$ & 1 \\
\hline 24 & 841 & Identification of Endogenous Social Effects & Manski & restud-93 & $\mathrm{C} 2$ & $\mathrm{D}$ & 1 \\
\hline
\end{tabular}




\begin{tabular}{|c|c|c|c|c|c|c|c|}
\hline Rank & $C_{i}(20)$ & Title & Authors & Journal & JEL & Type & USA \\
\hline 25 & 840 & A Simple Model of Herd Behavior & Banerjee & qje-92 & D8-D6 & $\mathrm{T}$ & 1 \\
\hline 26 & 822 & Productivity Growth, Technical Progress, and Effic & Fare et al. & aer-94 & $\mathrm{O} 4$ & $\mathrm{D}$ & 0.25 \\
\hline 27 & 766 & Distributive Politics and Economic Growth & Alesina ; Rodrik & qje-94 & O4-D7 & $\mathrm{D}$ & 1 \\
\hline 28 & 748 & Identification and Estimation of Local Average Tre & Imbens ; Angrist & ecma(s)-94 & C5 & $\mathrm{D}$ & 0.50 \\
\hline 29 & 744 & A Simple Estimator of Cointegrating Vectors in Hig & Stock ; Watson & ecma-93 & $\mathrm{C} 3-\mathrm{E} 4$ & $\mathrm{D}$ & 1 \\
\hline 30 & 740 & Corruption & Shleifer ; Vishny & qje-93 & D7-K4 & $\mathrm{T}$ & 1 \\
\hline 31 & 728 & R\&D-based models of economic growth & Jones & jpe-95 & $\mathrm{O} 4-\mathrm{O} 3$ & $\mathrm{~T}$ & 1 \\
\hline 32 & 720 & Income Distribution and Macroeconomics & Galor ; Zeira & restud-93 & $\mathrm{E} 2-\mathrm{E} 1$ & $\mathrm{~T}$ & 0.50 \\
\hline 33 & 706 & Is Inequality Harmful for Growth & Persson ; Tabellini & aer-94 & O4-D3 & $\mathrm{D}$ & 0 \\
\hline 34 & 699 & Learning, Mutation, and Long Run Equilibria in Gam & Kandori et al. & ecma-93 & $\mathrm{C} 7-\mathrm{D} 8$ & $\mathrm{~T}$ & 0.67 \\
\hline 35 & 671 & Wage Inequality and the Rise in Returns to Skill & Juhn et al. & jpe-93 & $\mathrm{J} 3$ & $\mathrm{D}$ & 1 \\
\hline 36 & 657 & Growth Empirics & Islam & qje-95 & $\mathrm{O} 4$ & $\mathrm{D}$ & 1 \\
\hline 37 & 647 & Long-Run Policy Analysis and Long-Run Growth & Rebelo & jpe-91 & O4-E6 & $\mathrm{T}$ & 0.67 \\
\hline 38 & 629 & Job Creation and Job Destruction in the Theory of & Mortensen ; Pissarides & restud-94 & $\mathrm{J} 4-\mathrm{E} 2$ & $\mathrm{~T}$ & 0.50 \\
\hline 39 & 608 & Bond Pricing and the Term Structure of Interest Ra & Heath et al. & ecma-92 & G1-E4 & $\mathrm{T}$ & 1 \\
\hline 40 & 598 & Automatic Lag Selection in Covariance Matrix Estim & Newey ; West & restud-94 & $\mathrm{C} 3$ & $\mathrm{D}$ & 1 \\
\hline 41 & 592 & Optimal Tests When a Nuisance Parameter Is Present & Andrews ; Ploberger & ecma-94 & $\mathrm{C} 1$ & $\mathrm{D}$ & 0.50 \\
\hline 42 & 588 & Changes in the Demand for Skilled Labor within U.S & Berman et al. & qje-94 & J2-L6 & $\mathrm{D}$ & 1 \\
\hline 43 & 575 & Globalization and the Inequality of Nations & Krugman ; Venables & qje-95 & F1 & $\mathrm{T}$ & 0.50 \\
\hline 44 & 571 & The Tyranny of Numbers & Young & qje-95 & O1 & $\mathrm{D}$ & 1 \\
\hline 45 & 568 & Tobin's q, Corporate Diversification, and Firm Per & Lang ; Stulz & jpe-94 & L2-G3 & $\mathrm{T}$ & 0.50 \\
\hline 46 & 556 & The Federal Funds Rate and the Channels of Monetar & Bernanke ; Blinder & aer-92 & E5 & $\mathrm{T}$ & 1 \\
\hline 47 & 554 & Economic Performance through Time & North & aer-94 & No & $\mathrm{T}$ & 1 \\
\hline 48 & 526 & Markov-Perfect Industry Dynamics & Ericson ; Pakes & restud-95 & L1 & $\mathrm{D}$ & 1 \\
\hline 49 & 518 & Politicians and Firms & Shleifer ; Vishny & qje-94 & L3-L3 & $\mathrm{T}$ & 1 \\
\hline 50 & 514 & Myopic Loss Aversion and the Equity Premium Puzzle & Benartzi ; Thaler & q.je-95 & G1 & $\mathrm{D}$ & 1 \\
\hline
\end{tabular}

\section{$4.2 \quad 1996-2000$}

Between 1996 and 2000 a total of 1,213 articles have been published in the top-5 journals. Table 5 gives the ranking of the 50 most cited articles for this time period. Note that the second column is now labelled $C_{i}(15)$, to indicate that the lifespan over which citations are counted for each article is 15 years here. This list is headed by "Law and Finance," an article published in JPE in 1998 and written by La porta et al. Again, many articles here appear also in the top- $1 \%$ list reported in Table 3. There are, however, a lot of newcomers as well. For instance, the article "Measuring Trust" by Glaeser et al., published in QJE in 2000, is ranked 25 th but is not among the papers listed in Table 3.

Table 5: Top 50 articles for $T=1996-2000$

\begin{tabular}{|c|c|c|c|c|c|c|c|}
\hline Rank & $C_{i}(15)$ & Title & Authors & Journal & JEL & Type & USA \\
\hline 1 & 2768 & Law and Finance & La Porta et al. & jpe-98 & $\mathrm{K} 2$ & $\mathrm{D}$ & 1 \\
\hline 2 & 1994 & A Theory of Fairness, Competition, and Cooperation & Fehr ; Schmidt & qje-99 & $\mathrm{D} 6-\mathrm{C} 7$ & $\mathrm{~T}$ & 0 \\
\hline 3 & 1495 & Why Do Some Countries Produce So Much More Output & Hall ; Jones & q.je-99 & $\mathrm{O} 4-\mathrm{E} 2$ & $\mathrm{D}$ & 1 \\
\hline 4 & 1326 & ERC & Bolton ; Ockenfels & aer-00 & $\mathrm{D} 6-\mathrm{C} 7$ & $\mathrm{~T}$ & 0.50 \\
\hline 5 & 1247 & Instrumental Variables Regression with Weak Instru & Staiger ; Stock & ecma-97 & $\mathrm{C} 3$ & $\mathrm{D}$ & 1 \\
\hline 7 & 1016 & Monetary Policy Rules and Macroeconomic Stability & Clarida et al. & qje-00 & E5 & $\mathrm{D}$ & 0.83 \\
\hline 8 & 965 & Financial Dependence and Growth & Rajan ; Zingales & aer-98 & E4-G2 & $\mathrm{D}$ & 1 \\
\hline 9 & 931 & Does Social Capital Have an Economic Payoff & Knack ; Keefer & qje-97 & $\mathrm{O} 4-\mathrm{P} 1$ & $\mathrm{D}$ & 1 \\
\hline 10 & 882 & R\&D spillovers and the geography of innovation an & Audretsch ; Feldman & $\operatorname{aer}(\mathrm{s})-96$ & O3-R1 & $\mathrm{D}$ & 0.50 \\
\hline 11 & 881 & Estimating and Testing Linear Models with Multiple & Bai ; Perron & ecma-98 & $\mathrm{C} 2$ & $\mathrm{D}$ & 0.50 \\
\hline 12 & 877 & Does Trade Cause Growth & Frankel ; Romer & aer-99 & $\mathrm{F} 4-\mathrm{O} 4$ & $\mathrm{D}$ & 1 \\
\hline 13 & 846 & Efficient Tests for an Autoregressive Unit Root & Elliott et al. & ecma-96 & $\mathrm{C} 2-\mathrm{C} 5$ & $\mathrm{D}$ & 1 \\
\hline
\end{tabular}




\begin{tabular}{|c|c|c|c|c|c|c|c|}
\hline Rank & $C_{i}(15)$ & Title & Authors & Journal & JEL & Type & USA \\
\hline 15 & 792 & By Force of Habit & Campbell ; Cochrane & jpe-99 & G1 & $\mathrm{T}$ & 1 \\
\hline 16 & 790 & Golden Eggs and Hyperbolic Discounting & Laibson & q.je-97 & D9-G1 & $\mathrm{D}$ & 1 \\
\hline 17 & 752 & Economics and Identity & Akerlof ; Kranton & qje-00 & D1-J1 & $\mathrm{T}$ & 1 \\
\hline 18 & 742 & The Twin Crises & Kaminsky ; Reinhart & aer-99 & F3-F3 & $\mathrm{D}$ & 1 \\
\hline 19 & 734 & Transform Analysis and Asset Pricing for Affine Ju & Duffie et al. & ecma-00 & G1 & $\mathrm{T}$ & 1 \\
\hline 20 & 719 & Aid, Policies, and Growth & Burnside ; Dollar & aer-00 & $\mathrm{O} 1-\mathrm{O} 2$ & $\mathrm{D}$ & 1 \\
\hline 21 & 682 & Do Domestic Firms Benefit from Direct Foreign Inve & Aitken ; Harrison & aer-99 & O1-F2 & $\mathrm{D}$ & 1 \\
\hline 22 & 648 & Matching as an Econometric Evaluation Estimator & Heckman et al. & restud-97 & $\mathrm{J} 2-\mathrm{C} 5$ & $\mathrm{D}$ & 1 \\
\hline 23 & 646 & The Effects of Human Resource Management Practices & Ichniowski et al. & aer-97 & $\mathrm{J} 2-\mathrm{L} 6$ & $\mathrm{D}$ & 1 \\
\hline 24 & 644 & Intellectual Human Capital and the Birth of U.S. B & Zucker et al. & $\operatorname{aer}(\mathrm{s})-98$ & L6-O3 & $\mathrm{D}$ & 1 \\
\hline 25 & 621 & Stock Markets, Banks, and Economic Growth & Levine ; Zervos & aer-98 & E4-G1 & $\mathrm{D}$ & 0.50 \\
\hline 25 & 621 & Measuring Trust & Glaeser et al. & qje-00 & $\mathrm{Z} 1$ & $\mathrm{E}$ & 0.25 \\
\hline 27 & 616 & Credit Cycles & Kiyotaki ; Moore & jpe-97 & E5-E3-E2 & $\mathrm{T}$ & 0.50 \\
\hline 29 & 522 & Doing It Now or Later & O'Donoghue ; Rabin & aer-99 & D9-D1 & $\mathrm{T}$ & 1 \\
\hline 30 & 515 & Predicting How People Play Games & Erev ; Roth & aer-98 & $\mathrm{C} 7-\mathrm{C} 9$ & $\mathrm{E}$ & 0.75 \\
\hline 31 & 513 & Public Goods and Ethnic Divisions & Alesina et al. & qje-99 & R5-J1 & $\mathrm{D}$ & 1 \\
\hline 32 & 509 & Output Fluctuations in the United States & McConnell ; Perez-Quiros & $\operatorname{aer}(\mathrm{s})-00$ & E3 & $\mathrm{T}$ & 0.50 \\
\hline 33 & 507 & Matching as an Econometric Evaluation Estimator & Heckman et al. & restud-98 & $\mathrm{C} 5-\mathrm{C} 2$ & $\mathrm{D}$ & 1 \\
\hline 34 & 506 & Formal and Real Authority in Organizations & Aghion ; Tirole & jpe-97 & D2 & $\mathrm{T}$ & 0 \\
\hline 35 & 494 & Financial Contagion & Allen ; Gale & jpe-00 & G2-E4 & $\mathrm{T}$ & 1 \\
\hline 36 & 493 & Population, Technology, and Growth & Galor ; Weil & aer-00 & $\mathrm{O} 4-\mathrm{O} 1$ & $\mathrm{~T}$ & 0.75 \\
\hline 37 & 480 & Are Recessions Good for Your Health & Ruhm & qje-00 & I1-E3 & $\mathrm{D}$ & 1 \\
\hline 38 & 477 & Characterizing Selection Bias Using Experimental D & Heckman et al. & ecma-98 & $\mathrm{C} 5-\mathrm{C} 2-\mathrm{J} 2$ & $\mathrm{E}$ & 0.25 \\
\hline 39 & 448 & Do Investment-Cash Flow Sensitivities Provide Usef & Kaplan ; Zingales & qje-97 & G3 & $\mathrm{D}$ & 1 \\
\hline 40 & 446 & Productivity and the Density of Economic Activity & Ciccone ; Hall & aer-96 & $\mathrm{R} 2-\mathrm{R} 1$ & $\mathrm{D}$ & 0.75 \\
\hline 40 & 446 & Entry, Exit, Growth, and Innovation over the Produ & Klepper & aer-96 & $\mathrm{L} 1$ & $\mathrm{~T}$ & 1 \\
\hline 42 & 440 & Computing Inequality & Autor et al. & qje-98 & O3-J3 & $\mathrm{D}$ & 1 \\
\hline 43 & 433 & Experience-Weighted Attraction Learning in Normal & Camerer ; Ho & ecma-99 & C7-D8 & $\mathrm{E}$ & 1 \\
\hline 46 & 421 & Zipf's Law for Cities & Gabaix & qje-99 & $\mathrm{R} 1$ & $\mathrm{D}$ & 1 \\
\hline 47 & 420 & Stochastic Volatility & Kim et al. & restud-98 & $\mathrm{C} 2-\mathrm{C} 5$ & $\mathrm{D}$ & 0.33 \\
\hline 48 & 419 & Labor Market Institutions and the Distribution of & DiNardo et al. & ecma-96 & J3 & $\mathrm{D}$ & 0.33 \\
\hline 49 & 417 & Participation in Heterogeneous Communities & Alesina ; La Ferrara & qje-00 & D7 & $\mathrm{D}$ & 0.50 \\
\hline 50 & 415 & Performance Pay and Productivity & Lazear & aer-00 & J3-J2 & $\mathrm{D}$ & 1 \\
\hline
\end{tabular}

\section{$4.3 \quad 2001-2005$}

Between 2001 and 2005 a total of 1,420 articles have been published, and Table 6 gives the ranking of the 50 most cited ones for this time period. At the top of this list is "How Much Should We Trust Differencesin-Differences Estimates?", written by Bertrand et al. and published in QJE in 2004. This article has accumulated an impressive number of citations over a relatively short time span (10 years).

Table 6: Top 50 articles for $T=2001-2005$

\begin{tabular}{|c|c|c|c|c|c|c|c|}
\hline Rank & $C_{i}(10)$ & Title & Authors & Journal & JEL & Type & USA \\
\hline 1 & 1253 & How Much Should We Trust Differences-in-Difference & Bertrand et al. & qje-04 & $\mathrm{C} 2-\mathrm{J} 3$ & $\mathrm{D}$ & 1 \\
\hline 2 & 1170 & The Impact of Trade on Intra-industry Reallocation & Melitz & ecma-03 & $\mathrm{F} 1-\mathrm{F} 2$ & $\mathrm{~T}$ & 1 \\
\hline 3 & 1150 & The Colonial Origins of Comparative Development & Acemoglu et al. & aer-01 & O1-I1 & $\mathrm{D}$ & 1 \\
\hline 4 & 1047 & Nominal Rigidities and the Dynamic Effects of a Sh & Christiano et al. & jpe-05 & E1-E3 & $\mathrm{T}$ & 1 \\
\hline 5 & 853 & Corporate Governance and Equity Prices & Gompers et al. & qje-03 & G1-G3 & $\mathrm{D}$ & 1 \\
\hline 6 & 753 & Gravity with Gravitas & Anderson ; van Wincoop & aer-03 & F1 & $\mathrm{D}$ & 1 \\
\hline 7 & 651 & Export versus FDI with Heterogeneous Firms & Helpman et al. & $\operatorname{aer}(\mathrm{s})-04$ & F1-F2 & $\mathrm{D}$ & 0.83 \\
\hline 8 & 617 & Teachers, Schools, and Academic Achievement & Rivkin et al. & ecma-05 & $\mathrm{I} 2$ & $\mathrm{D}$ & 0.67 \\
\hline
\end{tabular}




\begin{tabular}{|c|c|c|c|c|c|c|c|}
\hline Rank & $C_{i}(10)$ & Title & Authors & Journal & JEL & Type & USA \\
\hline 9 & 524 & Are Emily and Greg More Employable than Lakisha an & Bertrand ; Mullainathan & aer-04 & J1-J7 & $\mathrm{D}$ & 1 \\
\hline 10 & 508 & Unbundling Institutions & Acemoglu ; Johnson & jpe-05 & $\mathrm{B} 5-\mathrm{P} 1$ & $\mathrm{~T}$ & 1 \\
\hline 11 & 506 & Reversal of Fortune & Acemoglu et al. & qje-02 & D3-O1 & $\mathrm{D}$ & 1 \\
\hline 12 & 496 & Risk Aversion and Incentive Effects & Holt ; Laury & $\operatorname{aer}(\mathrm{s})-02$ & D8-D1 & $\mathrm{E}$ & 1 \\
\hline 13 & 490 & Competition and Innovation & Aghion et al. & q.je-05 & L1-O3 & $\mathrm{D}$ & 0.40 \\
\hline 14 & 480 & Lag Length Selection and the Construction of Unit & $\mathrm{Ng}$; Perron & ecma-01 & $\mathrm{C} 2$ & $\mathrm{D}$ & 1 \\
\hline 15 & 473 & The Regulation of Entry & Djankov et al. & qje-02 & L1-M1 & $\mathrm{D}$ & 0.25 \\
\hline 16 & 465 & Understanding Social Preferences with Simple Tests & Charness ; Rabin & qje-02 & D7 & $\mathrm{E}$ & 1 \\
\hline 17 & 448 & Modeling and Forecasting Realized Volatility & Andersen et al. & ecma-03 & C5 & $\mathrm{D}$ & 0.25 \\
\hline 18 & 446 & Estimating Production Functions Using Inputs to Co & Levinsohn ; Petrin & restud-03 & C5-L6-O1 & $\mathrm{D}$ & 1 \\
\hline 19 & 437 & Information Technology, Workplace Organization, an & Bresnahan et al. & qje-02 & $\mathrm{J} 2-\mathrm{O} 3$ & $\mathrm{D}$ & 1 \\
\hline 20 & 436 & Does Foreign Direct Investment Increase the Produc & Javorcik & aer-04 & $\mathrm{F} 2-\mathrm{O} 3$ & $\mathrm{D}$ & 1 \\
\hline 21 & 427 & Liquidity Risk and Expected Stock Returns & Pastor ; Stambaugh & jpe-03 & G1 & $\mathrm{D}$ & 1 \\
\hline 22 & 421 & The Cyclical Behavior of Equilibrium Unemployment & Shimer & aer-05 & $\mathrm{E} 2-\mathrm{J} 4$ & $\mathrm{~T}$ & 1 \\
\hline 23 & 418 & Plants and Productivity in International Trade & Bernard et al. & aer-03 & D2-F2 & $\mathrm{D}$ & 0.25 \\
\hline 24 & 417 & Neighbors as Negatives & Luttmer & qje-05 & D3-I3 & $\mathrm{D}$ & 1 \\
\hline 25 & 396 & The Regulation of Labor & Botero et al. & qje-04 & D7-J5-K3 & $\mathrm{D}$ & 1 \\
\hline 26 & 384 & The Modern History of Exchange Rate Arrangements & Reinhart ; Rogoff & qje-04 & $\mathrm{F} 3-\mathrm{N} 2$ & $\mathrm{D}$ & 1 \\
\hline 27 & 378 & Selection on Observed and Unobserved Variables & Altonji et al. & jpe-05 & $\mathrm{I} 2-\mathrm{Z} 1$ & $\mathrm{D}$ & 1 \\
\hline 27 & 378 & Some Evidence on the Importance of Sticky Prices & Bils ; Klenow & jpe-04 & E3-L1 & $\mathrm{D}$ & 1 \\
\hline 29 & 372 & Fear of Floating & Calvo ; Reinhart & qje-02 & F3-F3-O1 & $\mathrm{T}$ & 0.75 \\
\hline 30 & 364 & The Skill Content of Recent Technological Change & Autor et al. & qje-03 & J2-G3-J2 & $\mathrm{D}$ & 1 \\
\hline 31 & 359 & Economic Shocks and Civil Conflict & Miguel et al. & jpe-04 & $\mathrm{D} 7-\mathrm{O} 1$ & $\mathrm{D}$ & 1 \\
\hline 32 & 358 & Income Inequality in the United States, 1913-1998 & Piketty ; Saez & qje-03 & D3-N3 & $\mathrm{D}$ & 0.50 \\
\hline 33 & 355 & Determining the Number of Factors in Approximate F & Bai ; Ng & ecma-02 & $\mathrm{C} 3-\mathrm{G} 1$ & $\mathrm{D}$ & 1 \\
\hline 34 & 342 & Determinants of Long-Term Growth & Sala-i-Martin et al. & aer-04 & $\mathrm{C} 5-\mathrm{O} 4$ & $\mathrm{D}$ & 0.17 \\
\hline 35 & 341 & Worms & Miguel ; Kremer & ecma-04 & $\mathrm{I} 1-\mathrm{O} 1$ & $\mathrm{D}$ & 1 \\
\hline 36 & 319 & The Relationship between Education and Adult Morta & Lleras-Muney & restud-05 & I1-N3-N4 & $\mathrm{D}$ & 1 \\
\hline 37 & 318 & Technology, Geography, and Trade & Eaton ; Kortum & ecma-02 & F1-R1 & $\mathrm{D}$ & 1 \\
\hline 38 & 303 & The Labor Demand Curve Is Downward Sloping & Borjas & qje-03 & $\mathrm{J} 2-\mathrm{J} 2$ & $\mathrm{D}$ & 1 \\
\hline 38 & 303 & A Panic Attack on Unit Roots and Cointegration & Bai ; Ng & ecma-04 & $\mathrm{C} 2-\mathrm{C} 3$ & $\mathrm{D}$ & 1 \\
\hline 40 & 300 & Do We Really Know That the WTO Increases Trade & Rose & aer-04 & $\mathrm{F} 1$ & $\mathrm{D}$ & 1 \\
\hline 41 & 299 & The Variety and Quality of a Nation's Exports & Hummels ; Klenow & aer-05 & F1 & $\mathrm{D}$ & 1 \\
\hline 42 & 293 & Economic Status and Health in Childhood & Case et al. & aer-02 & I1-D3 & $\mathrm{T}$ & 0 \\
\hline 43 & 290 & Deception & Gneezy & $\operatorname{aer}(\mathrm{s})-05$ & D6-Z1 & $\mathrm{T}$ & 1 \\
\hline 44 & 289 & Financial Contracting Theory Meets the Real World & Kaplan ; Stromberg & restud-03 & G2-M1 & $\mathrm{D}$ & 1 \\
\hline 45 & 284 & Monetary Policy and Exchange Rate Volatility in a & Gali ; Monacelli & restud-05 & E5-F4 & $\mathrm{T}$ & 0 \\
\hline 46 & 282 & Intrinsic and Extrinsic Motivation & Benabou ; Tirole & restud-03 & D8-D1 & $\mathrm{T}$ & 0.75 \\
\hline 47 & 280 & Global Sourcing & Antras ; Helpman & jpe-04 & F1-L2 & $\mathrm{T}$ & 0.75 \\
\hline 48 & 279 & A Smooth Model of Decision Making under Ambiguity & Klibanoff et al. & ecma-05 & D8 & $\mathrm{T}$ & 0.33 \\
\hline 49 & 278 & Efficient Estimation of Average Treatment Effects & Hirano et al. & ecma-03 & $\mathrm{C} 2-\mathrm{C} 1$ & $\mathrm{D}$ & 1 \\
\hline 50 & 273 & The Role of Social Capital in Financial Developmen & Guiso et al. & aer-04 & D1-Z1 & $\mathrm{D}$ & 0.67 \\
\hline
\end{tabular}

\section{$4.4 \quad 2006-2010$}

For the period 2006-2010, a total of 1,347 articles are in our data base, and Table 7 gives the ranking of the 50 most cited articles for this time period. The article "Shocks and Frictions in US Business Cycles: A Bayesian DSGE Approach" by Smets and Wouters, and published in AER in 2007, is ranked first and has gathered 297 citations over a period of 5 years. None of the articles in this list appears in Table 3. Although these articles have accumulated an impressive number of citations in a short timespan, they are published very recently and cannot compete on an equal level with articles published in the early 1990s. 
Table 7: Top 50 articles for $T=2006-2010$

\begin{tabular}{|c|c|c|c|c|c|c|c|}
\hline Rank & $C_{i}(5)$ & Title & Authors & Journal & JEL & Type & USA \\
\hline 1 & 297 & Shocks and Frictions in US Business Cycles & Smets ; Wouters & aer-07 & D5-E3 & $\mathrm{D}$ & 0 \\
\hline 2 & 257 & Estimating Trade Flows & Helpman et al. & qje-08 & $\mathrm{F} 1$ & $\mathrm{D}$ & 1 \\
\hline 3 & 238 & Not All Oil Price Shocks Are Alike & Kilian & $\operatorname{aer}(\mathrm{s})-09$ & E3-Q4 & $\mathrm{D}$ & 1 \\
\hline 4 & 231 & Beyond Markets and States & Ostrom & aer-10 & D0-O1-Q2 & $\mathrm{T}$ & 1 \\
\hline 5 & 229 & Market Size, Trade, and Productivity & Melitz ; Ottaviano & restud-08 & F1 & $\mathrm{T}$ & 0.50 \\
\hline 6 & 226 & Experimental Analysis of Neighborhood Effects & Kling et al. & ecma-07 & I3-R2-R3 & $\mathrm{D}$ & 1 \\
\hline 7 & 222 & Misallocation and Manufacturing TFP in China and I & Hsieh ; Klenow & qje-09 & L6-O4 & $\mathrm{D}$ & 1 \\
\hline 8 & 191 & Social Preferences, Beliefs, and the Dynamics of F & Fischbacher ; Gachter & $\operatorname{aer}(\mathrm{s})-10$ & $\mathrm{D} 1-\mathrm{H} 4-\mathrm{Z} 1$ & $\mathrm{E}$ & 0 \\
\hline 9 & 183 & Why Has CEO Pay Increased So Much & Gabaix ; Landier & qje-08 & G3-M5 & $\mathrm{D}$ & 1 \\
\hline 10 & 181 & The Impact of Uncertainty Shocks & Bloom & ecma-09 & C5-D9 & $\mathrm{D}$ & 0.50 \\
\hline 11 & 175 & Did Securitization Lead to Lax Screening & Keys et al. & qje-10 & $\mathrm{G} 2$ & $\mathrm{D}$ & 0.50 \\
\hline 12 & 171 & Learning about a New Technology & Conley ; Udry & aer-10 & D8-O3-Q1 & $\mathrm{D}$ & 1 \\
\hline 13 & 170 & Do Women Shy Away from Competition & Niederle ; Vesterlund & q.je-07 & D1-J1 & $\mathrm{E}$ & 0.50 \\
\hline 14 & 165 & The Macroeconomic Effects of Tax Changes & Romer ; Romer & aer-10 & $\mathrm{E} 3-\mathrm{H} 2-\mathrm{N} 1$ & $\mathrm{D}$ & 1 \\
\hline 15 & 162 & The Consequences of Mortgage Credit Expansion & Mian ; Sufi & q.je-09 & D1-R3 & $\mathrm{D}$ & 1 \\
\hline 16 & 158 & Trading Tasks & Grossman ; Rossi-Hansberg & aer-08 & F1-M1 & $\mathrm{T}$ & 1 \\
\hline 16 & 158 & Large Sample Properties of Matching Estimators for & Abadie ; Imbens & ecma(s)-06 & $\mathrm{C} 2$ & $\mathrm{D}$ & 1 \\
\hline 18 & 157 & Estimating the Technology of Cognitive and Noncogn & Cunha et al. & ecma-10 & $\mathrm{C} 5-\mathrm{J} 1$ & $\mathrm{D}$ & 0.83 \\
\hline 19 & 154 & Internet Advertising and the Generalized Second-Pr & Edelman et al. & aer-07 & $\mathrm{D} 4-\mathrm{M} 3$ & $\mathrm{~T}$ & 0.67 \\
\hline 20 & 150 & Income and Democracy & Acemoglu et al. & aer-08 & $\mathrm{D} 7-\mathrm{O} 4$ & $\mathrm{D}$ & 0.88 \\
\hline 21 & 149 & Measuring and Explaining Management Practices acro & Bloom ; Van Reenen & qje-07 & L2-M1 & $\mathrm{D}$ & 0.25 \\
\hline 22 & 148 & Distorted Gravity & Chaney & $\operatorname{aer}(\mathrm{s})-08$ & $\mathrm{~F} 1$ & $\mathrm{~T}$ & 1 \\
\hline 23 & 145 & Five Facts about Prices & Nakamura ; Steinsson & qje-08 & E2-E3 & $\mathrm{D}$ & 1 \\
\hline 24 & 144 & Incentives and Prosocial Behavior & Benabou ; Tirole & aer-06 & D1-D8-Z1 & $\mathrm{T}$ & 0.25 \\
\hline 24 & 144 & Teacher Quality in Educational Production & Rothstein & qje-10 & $\mathrm{H} 7-\mathrm{J} 4$ & $\mathrm{D}$ & 1 \\
\hline 26 & 139 & Reallocation, Firm Turnover, and Efficiency & Foster et al. & aer-08 & D2-L2 & $\mathrm{T}$ & 1 \\
\hline 26 & 139 & Trade, Quality Upgrading, and Wage Inequality in t & Verhoogen & q.je-08 & $\mathrm{F} 1$ & $\mathrm{D}$ & 1 \\
\hline 26 & 139 & Designing Realized Kernels to Measure the Ex Post & Barndorff-Nielsen et al. & ecma-08 & C5-G1 & $\mathrm{D}$ & 0.25 \\
\hline 26 & 139 & Were There Regime Switches in U.S. Monetary Policy & Sims ; Zha & aer-06 & E3-E5 & $\mathrm{D}$ & 1 \\
\hline 30 & 138 & Cultural Biases in Economic Exchange & Guiso et al. & qje-09 & $\mathrm{F} 1-\mathrm{Z} 1$ & $\mathrm{D}$ & 0.67 \\
\hline 30 & 138 & Salience and Taxation & Chetty et al. & aer-09 & $\mathrm{C} 9-\mathrm{H} 2-\mathrm{H} 7$ & $\mathrm{D}$ & 1 \\
\hline 32 & 133 & What Drives Media Slant & Gentzkow ; Shapiro & ecma-10 & $\mathrm{C} 5-\mathrm{L} 8$ & $\mathrm{D}$ & 1 \\
\hline 33 & 131 & Doing Good or Doing Well & Ariely et al. & $\operatorname{aer}(\mathrm{s})-09$ & D6-Z1 & $\mathrm{T}$ & 0.67 \\
\hline 33 & 131 & Stature and Status & Case ; Paxson & jpe-08 & J1-J7 & $\mathrm{D}$ & 1 \\
\hline 35 & 128 & Are Risk Aversion and Impatience Related to Cognit & Dohmen et al. & $\operatorname{aer}(\mathrm{s})-10$ & D1-D8 & $\mathrm{E}$ & 0.25 \\
\hline 36 & 127 & What Causes Industry Agglomeration & Ellison et al. & aer-10 & $\mathrm{L} 1-\mathrm{O} 3$ & $\mathrm{D}$ & 1 \\
\hline 37 & 126 & Globalization and the Gains from Variety & Broda ; Weinstein & qje-06 & F1 & $\mathrm{D}$ & 1 \\
\hline 38 & 123 & Politically Connected Firms & Faccio & $\operatorname{aer}(\mathrm{s})-06$ & D7-O1 & $\mathrm{T}$ & 1 \\
\hline 39 & 120 & Group Identity and Social Preferences & Chen ; Li & aer-09 & $\mathrm{C} 9-\mathrm{Z} 1$ & $\mathrm{E}$ & 1 \\
\hline 39 & 120 & The Geographic Determinants of Housing Supply & Saiz & qje-10 & Q2-R3 & $\mathrm{D}$ & 1 \\
\hline 39 & 120 & Peers at Work & Mas ; Moretti & aer-09 & $\mathrm{J} 2-\mathrm{M} 5$ & $\mathrm{D}$ & 1 \\
\hline 39 & 120 & Eliciting Risk and Time Preferences & Andersen et al. & ecma-08 & D1-D9 & $\mathrm{E}$ & 0.75 \\
\hline 43 & 116 & Inequality and Unemployment in a Global Economy & Helpman et al. & ecma-10 & $\mathrm{D} 2-\mathrm{J} 2$ & $\mathrm{~T}$ & 0.67 \\
\hline 43 & 116 & An Equilibrium Model of 'Global Imbalances' and Lo & Caballero et al. & aer-08 & E4-F3 & $\mathrm{T}$ & 1 \\
\hline 43 & 116 & A Model of Reference-Dependent Preferences & Koszegi ; Rabin & qje-06 & D1 & $\mathrm{T}$ & 1 \\
\hline 46 & 114 & The Cyclical Behavior of Equilibrium Unemployment & Hagedorn ; Manovskii & $\operatorname{aer}(\mathrm{s})-08$ & E2-J3 & $\mathrm{D}$ & 0.50 \\
\hline 46 & 114 & Inequality in Landownership, the Emergence of Huma & Galor et al. & restud-09 & D0-I2 & $\mathrm{D}$ & 0.67 \\
\hline 46 & 114 & Social Image and the Fifty-Fifty Norm & Andreoni ; Bernheim & ecma-09 & C7-D6 & $\mathrm{E}$ & 1 \\
\hline 49 & 108 & Can News about the Future Drive the Business Cycle & Jaimovich ; Rebelo & aer-09 & E1-E3 & $\mathrm{T}$ & 1 \\
\hline 50 & 103 & Shrouded Attributes, Consumer Myopia, and Informat & Gabaix ; Laibson & qje-06 & D1-L1 & $\mathrm{T}$ & 1 \\
\hline
\end{tabular}




\section{$4.5 \quad 2011-2015$}

In the most recent period that we consider, 2011-2015, 1,465 articles have been published. Table 8 lists the papers on the basis of citations obtained up to two years after publications. Note that for articles published in 2014 or 2015 the lifetime span is thus a bit shorter than two years. The article "The Oregon Health Insurance Experiment" by Finkelstein et al., published in QJE in 2012 ranks first with 75 citations. All articles on this list have gathered a large number of citations in their early career, and many of them will surely be among the high flyers in the near future.

Table 8: Top 50 articles for $T=2011-2015$

\begin{tabular}{|c|c|c|c|c|c|c|c|}
\hline Rank & $C_{i}(2)$ & Title & Authors & Journal & JEL & Type & USA \\
\hline 1 & 75 & The Oregon Health Insurance Experiment & Finkelstein et al. & qje-12 & $\mathrm{H} 7-\mathrm{I} 3$ & $\mathrm{D}$ & 0.13 \\
\hline 2 & 67 & The "Out of Africa" Hypothesis, Human Genetic Dive & Ashraf ; Galor & aer-13 & N1-N5 & $\mathrm{D}$ & 1 \\
\hline 3 & 65 & The Environment and Directed Technical Change & Acemoglu et al. & aer-12 & O3-Q3 & $\mathrm{T}$ & 0.88 \\
\hline 4 & 64 & Identifying Government Spending Shocks & Ramey & qje-11 & D8-H5 & $\mathrm{D}$ & 1 \\
\hline 5 & 63 & The Growth of Low-Skill Service Jobs and the Polar & Autor ; Dorn & aer-13 & $\mathrm{J} 2-\mathrm{R} 2$ & $\mathrm{~T}$ & 0.50 \\
\hline 6 & 62 & New Trade Models, Same Old Gains & Arkolakis et al. & aer-12 & $\mathrm{F} 1$ & $\mathrm{D}$ & 1 \\
\hline 7 & 61 & Trade Liberalization, Exports, and Technology Upgr & Bustos & aer-11 & F1-O1 & $\mathrm{D}$ & 0 \\
\hline 8 & 59 & Credit Booms Gone Bust & Schularick ; Taylor & $\operatorname{aer}(\mathrm{s})-12$ & E3-E5 & $\mathrm{D}$ & 0.50 \\
\hline 9 & 57 & Testing for Altruism and Social Pressure in Charit & DellaVigna et al. & qje-12 & D6-L3 & $\mathrm{D}$ & 1 \\
\hline 10 & 55 & Does Management Matter & Bloom et al. & qje-13 & D2-L1 & $\mathrm{D}$ & 0.90 \\
\hline 11 & 53 & When Is the Government Spending Multiplier Large & Christiano et al. & jpe-11 & E2-G0-H5 & $\mathrm{T}$ & 1 \\
\hline 12 & 52 & Credit Constraints, Heterogeneous Firms, and Inter & Manova & restud-13 & F1-G3 & $\mathrm{D}$ & 1 \\
\hline 13 & 48 & An Anatomy of International Trade & Eaton et al. & ecma-11 & C5 & $\mathrm{D}$ & 0.67 \\
\hline 14 & 47 & Credit Spreads and Business Cycle Fluctuations & Gilchrist ; Zakrajsek & $\operatorname{aer}(\mathrm{s})-12$ & E3-G1-G3 & $\mathrm{D}$ & 1 \\
\hline 16 & 46 & The China Syndrome & Autor et al. & aer-13 & $\mathrm{E} 2$ & $\mathrm{D}$ & 0.67 \\
\hline 17 & 44 & The Intergenerational Transmission of Risk and Tru & Dohmen et al. & restud-12 & D8-Z1 & $\mathrm{D}$ & 0.25 \\
\hline 18 & 42 & From Financial Crash to Debt Crisis & Reinhart ; Rogoff & aer-11 & E4-F4 & $\mathrm{D}$ & 1 \\
\hline 18 & 42 & A Macroeconomic Model with a Financial Sector & Brunnermeier ; Sannikov & aer-14 & $\mathrm{E} 1-\mathrm{E} 4$ & $\mathrm{~T}$ & 1 \\
\hline 18 & 42 & Collective Moral Hazard, Maturity Mismatch, and Sy & Farhi ; Tirole & aer-12 & D8 & $\mathrm{T}$ & 0.50 \\
\hline 21 & 41 & Macroeconomic Effects of Financial Shocks & Jermann ; Quadrini & aer-12 & $\mathrm{E} 2-\mathrm{E} 4$ & $\mathrm{~T}$ & 1 \\
\hline 21 & 41 & Commodity Price Shocks and Civil Conflict & Dube ; Vargas & restud-13 & $\mathrm{D} 7$ & $\mathrm{D}$ & 0.50 \\
\hline 23 & 40 & Debt, Deleveraging, and the Liquidity Trap & Eggertsson ; Krugman & qje-12 & E1-E3 & $\mathrm{D}$ & 1 \\
\hline 23 & 40 & Cross-Country Differences in Productivity & Bartelsman et al. & aer-13 & $\mathrm{D} 2-\mathrm{O} 4$ & $\mathrm{D}$ & 0.33 \\
\hline 23 & 40 & The Changing of the Boards & Ahern ; Dittmar & qje-12 & G1-G3 & $\mathrm{D}$ & 1 \\
\hline 23 & 40 & Risk Shocks & Christiano et al. & aer-14 & D8-E3 & $\mathrm{D}$ & 0.33 \\
\hline 27 & 39 & Understanding the Mechanisms through Which an Infl & Heckman et al. & aer-13 & $\mathrm{I} 2$ & $\mathrm{E}$ & 0.83 \\
\hline 27 & 39 & Multiproduct Firms and Trade Liberalization & Bernard et al. & qje-11 & F1-L1 & $\mathrm{D}$ & 1 \\
\hline 29 & 38 & Americans Do IT Better & Bloom et al. & aer-12 & $\mathrm{D} 2-\mathrm{F} 2$ & $\mathrm{D}$ & 0.33 \\
\hline 31 & 36 & Depression Babies & Malmendier ; Nagel & qje-11 & D1-G1 & $\mathrm{D}$ & 1 \\
\hline 31 & 36 & Optimal Bandwidth Choice for the Regression Discon & Imbens ; Kalyanaraman & restud-12 & $\mathrm{C} 1-\mathrm{C} 2$ & $\mathrm{D}$ & 0.50 \\
\hline 34 & 35 & Human Capital and Regional Development & Gennaioli et al. & qje-13 & $\mathrm{J} 2-\mathrm{L} 2$ & $\mathrm{D}$ & 0.50 \\
\hline 34 & 35 & Innovation and Institutional Ownership & Aghion et al. & aer-13 & G2-L2 & $\mathrm{T}$ & 0.67 \\
\hline 34 & 35 & Bounds on Elasticities with Optimization Frictions & Chetty & ecma-12 & C5-H3-J2 & $\mathrm{D}$ & 1 \\
\hline 37 & 33 & Choice Inconsistencies among the Elderly & Abaluck ; Gruber & aer-11 & D1-J1 & $\mathrm{D}$ & 1 \\
\hline 37 & 33 & What's News in Business Cycles & Schmitt-Grohe ; Uribe & ecma-12 & C5 & $\mathrm{D}$ & 1 \\
\hline 39 & 32 & Export Prices across Firms and Destinations & Manova ; Zhang & qje-12 & F1-P3 & $\mathrm{D}$ & 0.75 \\
\hline 39 & 32 & Violent Conflict and Behavior & Voors et al. & aer-12 & C9-D7 & $\mathrm{D}$ & 0 \\
\hline 39 & 32 & How Does Your Kindergarten Classroom Affect Your E & Chetty et al. & qje-11 & $\mathrm{I} 2-\mathrm{J} 2$ & $\mathrm{E}$ & 1 \\
\hline 39 & 32 & The Impact of Family Income on Child Achievement & Dahl ; Lochner & aer-12 & $\mathrm{H} 2-\mathrm{I} 2$ & $\mathrm{D}$ & 0.50 \\
\hline 39 & 32 & Prices, Plant Size, and Product Quality & Kugler ; Verhoogen & restud-12 & D2-L2 & $\mathrm{D}$ & 1 \\
\hline 44 & 31 & Intersection Bounds & Chernozhukov et al. & ecma-13 & $\mathrm{C} 1$ & $\mathrm{D}$ & 0.33 \\
\hline 45 & 30 & Intermediary Asset Pricing & He ; Krishnamurthy & aer-13 & E4-G2 & $\mathrm{T}$ & 1 \\
\hline 45 & 30 & Environmental Accounting for Pollution in the Unit & Muller et al. & aer-11 & E0-Q5 & $\mathrm{D}$ & 1 \\
\hline 45 & 30 & Do Consumers Respond to Marginal or Average Price & Ito & aer-14 & D1-L9 & $\mathrm{D}$ & 1 \\
\hline 45 & 30 & The Effect of Education on Adult Mortality and Hea & Clark ; Royer & aer-13 & $\mathrm{H} 5-\mathrm{I} 2$ & $\mathrm{D}$ & 1 \\
\hline 45 & 30 & Identifying Technology Spillovers and Product Mark & Bloom et al. & ecma-13 & $\mathrm{D} 2-\mathrm{O} 3$ & $\mathrm{D}$ & 0.33 \\
\hline
\end{tabular}




\begin{tabular}{|c|c|c|c|c|c|c|c|}
\hline Rank & $C_{i}(2)$ & Title & Authors & Journal & JEL & Type & USA \\
\hline 50 & 29 & Nudging Farmers to Use Fertilizer & Duflo et al. & aer-11 & Q1 & $\mathrm{E}$ & 0.83 \\
\hline 50 & 29 & Forced Sales and House Prices & Campbell et al. & $\operatorname{aer}(\mathrm{s})-11$ & D1-R3 & $\mathrm{D}$ & 1 \\
\hline
\end{tabular}

\section{Normalized citations by publication year}

In the previous section we have listed the most cited articles by five-year periods wherein the papers were published. These listings are difficult to compare across the different subperiods because the time span over which the cumulated citations are calculated vary (e.g., the time span corresponding to Table 4 is 20 years, while the one corresponding to Table 7 is only 5 years). Even within a subperiod, articles are not completely comparable because in our data there is a clear upward trend in the number of citations. This increasing number of citations over time is due to an increase in the number of journals (that can cite our top-5 articles), and also because reference lists in academic articles tend to get longer and longer. ${ }^{11}$ To account for these two factors, we present in this section listings based on normalized citations.

Let $C_{i}$ be the cumulated number of citations gathered by article $i$ at the end of 2015. Furthermore, let $I(t)$ denote the set of all articles published in year $t$ in the five journals, and $N_{t}$ the total number of articles published in that year (i.e., the number of elements in $I(t)), t=1991, \cdots, 2015$. Finally, let $t_{i}$ be the publication year of article $i$. Our normalized number of citations, denoted $\widetilde{C_{i}}$, is now defined as

$$
\widetilde{C_{i}}=100 \frac{C_{i}}{\overline{C_{t_{i}}}}
$$

where $\overline{C_{t_{i}}}$ is the average number of cumulated citations received per article published in year $t_{i}$, i.e., $\overline{C_{t_{i}}}=$ $\frac{1}{N_{t_{i}}} \sum_{j \in I\left(t_{i}\right)} C_{j}$. The interesting property of $\widetilde{C}_{i}$ is that it has the same mean for all publication years.

The figures in Figure 1 help to visualize the impact of our normalization. The left hand-side figure plots for each year (from 1991 to 2015) and for each journal the median of $C_{i}$ whereas the right hand-side figure plots the same information but for $\widetilde{C_{i}}$. After normalization there are still variations (for a given journal) across time but much less so than before the normalization. The medians for 2015 are quite erratic as the articles had less than one year to be cited.

Figure 1: Median citations per year
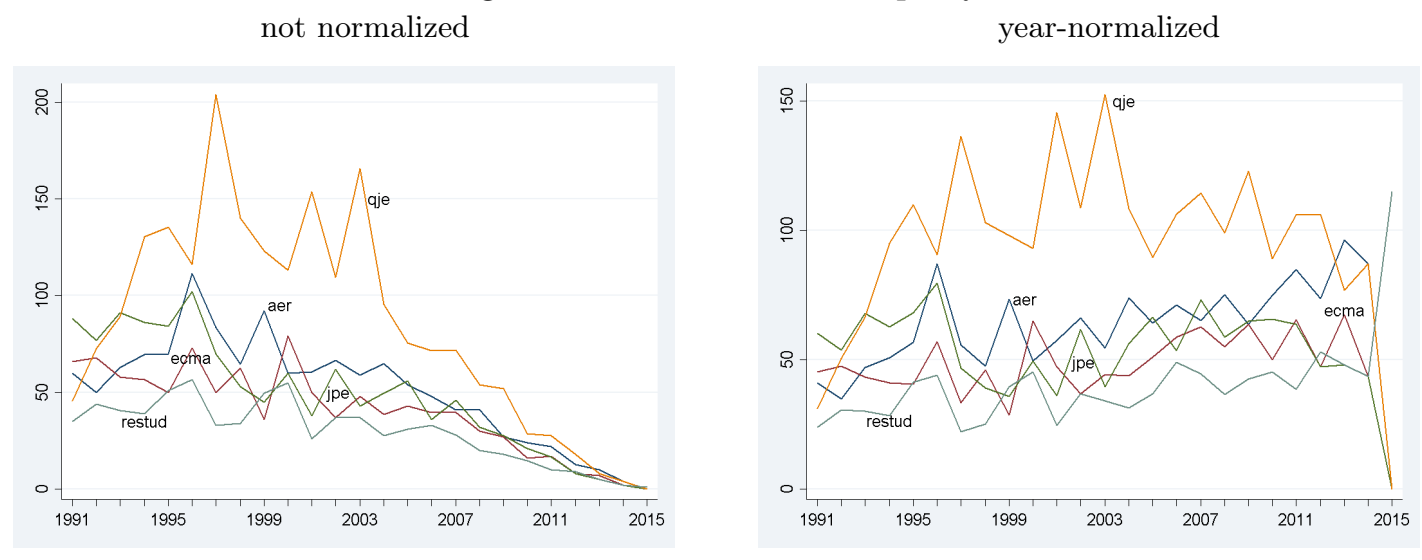

\footnotetext{
${ }^{11}$ This upward trend in the length of reference lists is also mentioned in Ellison (2002). In our data, among the articles published during 1991-1995, the average number of references per article is 25.8, while among articles published during 20112015 it is 44.8 .
} 
Table 9 summarizes the distributions of the year-normalized citations. Compared to Table 2, QJE is still dominant at each percentile. The JPE concedes its second place to the AER and is now closely followed by ECMA.

Table 9: Year-normalized citations

\begin{tabular}{lrrrrrrrrrrrrr}
\hline \hline & $\mathrm{N}$ & mean & $\sigma$ & min & $\mathrm{p} 5$ & $\mathrm{p} 10$ & $\mathrm{p} 25$ & $\mathrm{p} 50$ & $\mathrm{p} 75$ & $\mathrm{p} 90$ & $\mathrm{p} 95$ & $\mathrm{p} 99$ & $\max$ \\
\hline aer (r) & 1,555 & 115.42 & 144.20 & 0 & 1 & 14 & 35 & 75 & 138 & 245 & 348 & 695 & 1,840 \\
aer (s) & 689 & 79.14 & 109.82 & 0 & 4 & 8 & 21 & 46 & 93 & 177 & 260 & 597 & 1,024 \\
\hline aer (all) & 2,244 & 104.28 & 135.59 & 0 & 3 & 11 & 29 & 65 & 125 & 230 & 330 & 653 & 1,840 \\
\hline ecma (r) & 1,078 & 99.03 & 145.38 & 0 & 6 & 12 & 28 & 57 & 115 & 212 & 344 & 743 & 1,637 \\
ecma (s) & 351 & 53.50 & 75.54 & 0 & 1 & 5 & 14 & 30 & 60 & 115 & 193 & 393 & 613 \\
\hline ecma (all) & 1,429 & 87.85 & 133.13 & 0 & 4 & 9 & 22 & 49 & 102 & 194 & 308 & 613 & 1,637 \\
\hline jpe & 1,021 & 93.11 & 139.50 & 0 & 6 & 12 & 26 & 53 & 115 & 201 & 269 & 575 & 2,475 \\
qje & 1,053 & 144.57 & 181.98 & 0 & 6 & 16 & 41 & 96 & 175 & 305 & 453 & 888 & 1,815 \\
restud & 1,069 & 69.94 & 128.30 & 0 & 4 & 7 & 18 & 38 & 78 & 154 & 230 & 486 & 2,935 \\
\hline All & 6,816 & 100.00 & 144.44 & 0 & 4 & 10 & 26 & 58 & 119 & 223 & 321 & 680 & 2,935 \\
\hline
\end{tabular}

Table 10 lists the top $1 \%$ of the most cited articles once citations are normalized. ${ }^{12}$ To highlight the changes with respect to Table 3 we put two ranks: $\widetilde{R}$ is the rank in terms of normalized citations whereas $\mathrm{R}$ is the rank before the normalization. The column $\widetilde{C_{i}}$ gives the value of the normalized citations and in parenthesis the number of citations $C_{i}$. We also colored in red the titles of the articles which are not in the top $1 \%$ before the normalization. Otherwise the structure of the table is the same.

Table 10: Articles in the top 1\% for $T=1991-2014$, citations normalized per year

\begin{tabular}{|c|c|c|c|c|c|c|c|}
\hline$\widetilde{R}(\mathrm{R})$ & $\widetilde{C_{i}}\left(C_{i}\right)$ & Title & Authors & Journal & JEL & Type & USA \\
\hline $1(1)$ & $2935(4285)$ & Some Tests of Specification for Panel Data & Arellano ; Bond & restud-91 & $\mathrm{C} 2-\mathrm{J} 2$ & $\mathrm{D}$ & 0 \\
\hline $2(2)$ & $2475(3362)$ & Law and Finance & La Porta et al. & jpe-98 & $\mathrm{K} 2$ & $\mathrm{D}$ & 1 \\
\hline $3(8)$ & $1840(1940)$ & The Colonial Origins of Comparative Development & Acemoglu et al. & aer-01 & O1-I1 & $\mathrm{D}$ & 1 \\
\hline $4(4)$ & $1815(2274)$ & A Theory of Fairness, Competition, and Cooperation & Fehr ; Schmidt & qje-99 & $\mathrm{D} 6-\mathrm{C} 7$ & $\mathrm{~T}$ & 0 \\
\hline $5(17)$ & $1692(1489)$ & How Much Should We Trust Differences-in-Difference & Bertrand et al. & q.je-04 & $\mathrm{C} 2-\mathrm{J} 3$ & $\mathrm{D}$ & 1 \\
\hline $6(12)$ & $1637(1774)$ & The Impact of Trade on Intra-industry Reallocation & Melitz & ecma-03 & $\mathrm{F} 1-\mathrm{F} 2$ & $\mathrm{~T}$ & 1 \\
\hline $7(3)$ & $1609(2349)$ & Economic Growth in a Cross Section of Countries & Barro & q.je-91 & O4-O5 & $\mathrm{D}$ & 1 \\
\hline $8(5)$ & $1543(2252)$ & Estimation and Hypothesis Testing of Cointegration & Johansen & ecma-91 & C3 & $\mathrm{D}$ & 0 \\
\hline $9(6)$ & $1491(2176)$ & Increasing Returns and Economic Geography & Krugman & jpe-91 & R1-R3 & $\mathrm{T}$ & 1 \\
\hline $10(7)$ & $1447(2075)$ & A Contribution to the Empirics of Economic Growth & Mankiw et al. & q.je-92 & $\mathrm{O} 4$ & $\mathrm{D}$ & 1 \\
\hline $11(10)$ & $1429(1917)$ & Geographic Localization of Knowledge Spillovers as & Jaffe et al. & qje-93 & O3 & $\mathrm{D}$ & 0.67 \\
\hline $12(9)$ & $1319(1926)$ & Conditional Heteroskedasticity in Asset Returns & Nelson & ecma-91 & $\mathrm{C} 5-\mathrm{G} 1$ & $\mathrm{D}$ & 1 \\
\hline $13(13)$ & $1291(1617)$ & Why Do Some Countries Produce So Much More Output & Hall ; Jones & qje-99 & $\mathrm{O} 4-\mathrm{E} 2$ & $\mathrm{D}$ & 1 \\
\hline $14(40)$ & $1243(1047)$ & Nominal Rigidities and the Dynamic Effects of a Sh & Christiano et al. & jpe-05 & $\mathrm{E} 1-\mathrm{E} 3$ & $\mathrm{~T}$ & 1 \\
\hline $15(11)$ & $1237(1850)$ & Instrumental Variables Regression with Weak Instru & Staiger ; Stock & ecma-97 & $\mathrm{C} 3$ & $\mathrm{D}$ & 1 \\
\hline $16(15)$ & $1231(1516)$ & Corruption and Growth & Mauro & qje-95 & D7 & $\mathrm{D}$ & 1 \\
\hline $17(18)$ & $1118(1430)$ & Efficient Tests for an Autoregressive Unit Root & Elliott et al. & ecma-96 & $\mathrm{C} 2-\mathrm{C} 5$ & $\mathrm{D}$ & 1 \\
\hline $18(25)$ & $1092(1326)$ & $\mathrm{ERC}$ & Bolton ; Ockenfels & aer-00 & $\mathrm{D} 6-\mathrm{C} 7$ & $\mathrm{~T}$ & 0.50 \\
\hline $19(30)$ & $1077(1167)$ & Corporate Governance and Equity Prices & Gompers et al. & qje-03 & G1-G3 & $\mathrm{D}$ & 1 \\
\hline $20(14)$ & $1070(1534)$ & A Sensitivity Analysis of Cross-Country Growth Reg & Levine ; Renelt & aer-92 & $\mathrm{O} 4$ & $\mathrm{D}$ & 1 \\
\hline $21(16)$ & $1055(1512)$ & A Model of Growth through Creative Destruction & Aghion ; Howitt & ecma-92 & $\mathrm{O} 4-\mathrm{O} 3$ & $\mathrm{~T}$ & 0 \\
\hline $22(26)$ & $1024(1310)$ & R\&D spillovers and the geography of innovation an & Audretsch ; Feldman & $\operatorname{aer}(\mathrm{s})-96$ & O3-R1 & $\mathrm{D}$ & 0.50 \\
\hline $23(21)$ & $1015(1361)$ & Incorporating Fairness into Game Theory and Econom & Rabin & aer-93 & $\mathrm{C} 7-\mathrm{D} 6$ & $\mathrm{~T}$ & 1 \\
\hline $24(91)$ & $976(614)$ & Shocks and Frictions in US Business Cycles & Smets ; Wouters & aer-07 & D5-E3 & $\mathrm{D}$ & 0 \\
\hline
\end{tabular}

\footnotetext{
${ }^{12}$ Articles published in 2015 are excluded because especially the ones published towards the end of that year had little time to obtain citations, and also because, as mentioned earlier, for all journals except AER the last issues are not (yet) included in EconLit.
} 


\begin{tabular}{|c|c|c|c|c|c|c|c|}
\hline$\widetilde{R}(\mathrm{R})$ & $\widetilde{C_{i}}\left(C_{i}\right)$ & Title & Authors & Journal & JEL & Type & USA \\
\hline $25(39)$ & $972(1054)$ & Gravity with Gravitas & Anderson ; van Wincoop & aer-03 & F1 & $\mathrm{D}$ & 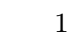 \\
\hline $26(19)$ & $963(1406)$ & Loss Aversion in Riskless Choice & Tversky ; Kahneman & qje-91 & D1 & $\mathrm{E}$ & 1 \\
\hline $27(47)$ & $959(964)$ & Risk Aversion and Incentive Effects & Holt ; Laury & $\operatorname{aer}(\mathrm{s})-02$ & D8-D1 & $\mathrm{E}$ & 1 \\
\hline $28(20)$ & $958(1374)$ & A Theory of Fads, Fashion, Custom, and Cultural Ch & Bikhchandani et al. & jpe-92 & D7-D8 & $\mathrm{T}$ & 1 \\
\hline $29(23)$ & $930(1333)$ & Convergence & Barro ; Sala-i-Martin & jpe-92 & $\mathrm{O} 4-\mathrm{N} 1$ & $\mathrm{D}$ & 1 \\
\hline $30(22)$ & $918(1340)$ & The Penn World Table (Mark 5) & Summers ; Heston & q.je-91 & O5-E1 & $\mathrm{D}$ & 1 \\
\hline $31(3098)$ & $915(42)$ & A Macroeconomic Model with a Financial Sector & Brunnermeier ; Sannikov & aer-14 & $\mathrm{E} 1-\mathrm{E} 4$ & $\mathrm{~T}$ & 1 \\
\hline $32(29)$ & $894(1214)$ & Financial Dependence and Growth & Rajan ; Zingales & aer-98 & $\mathrm{E} 4-\mathrm{G} 2$ & $\mathrm{D}$ & 1 \\
\hline $33(24)$ & $888(1328)$ & Does Social Capital Have an Economic Payoff & Knack ; Keefer & q.je-97 & $\mathrm{O} 4-\mathrm{P} 1$ & $\mathrm{D}$ & 1 \\
\hline $34(3204)$ & $871(40)$ & Risk Shocks & Christiano et al. & aer-14 & D8-E3 & $\mathrm{D}$ & 0.33 \\
\hline $35(27)$ & $865(1263)$ & Heteroskedasticity and Autocorrelation Consistent & Andrews & ecma-91 & $\mathrm{C} 2$ & $\mathrm{D}$ & 1 \\
\hline $36(28)$ & $852(1221)$ & Growth in Cities & Glaeser et al. & jpe-92 & $\mathrm{R} 1-\mathrm{O} 4$ & $\mathrm{D}$ & 0.25 \\
\hline $37(41)$ & $850(1032)$ & Cooperation and Punishment in Public Goods Experim & Fehr ; Gachter & $\operatorname{aer}(\mathrm{s})-00$ & $\mathrm{H} 4$ & $\mathrm{E}$ & 0 \\
\hline $38(33)$ & $849(1138)$ & Identification of Endogenous Social Effects & Manski & restud-93 & $\mathrm{C} 2$ & $\mathrm{D}$ & 1 \\
\hline $39(34)$ & $837(1137)$ & Estimating and Testing Linear Models with Multiple & Bai ; Perron & ecma-98 & $\mathrm{C} 2$ & $\mathrm{D}$ & 0.50 \\
\hline $40(44)$ & $837(1016)$ & Monetary Policy Rules and Macroeconomic Stability & Clarida et al. & q.je-00 & E5 & $\mathrm{D}$ & 0.83 \\
\hline $41(70)$ & $833(733)$ & Export versus FDI with Heterogeneous Firms & Helpman et al. & $\operatorname{aer}(\mathrm{s})-04$ & $\mathrm{~F} 1-\mathrm{F} 2$ & $\mathrm{D}$ & 0.83 \\
\hline $42(43)$ & $831(1023)$ & Economic Growth and the Environment & Grossman ; Krueger & q.je-95 & O4-Q2 & $\mathrm{D}$ & 1 \\
\hline $43(53)$ & $830(875)$ & Lag Length Selection and the Construction of Unit & $\mathrm{Ng}$; Perron & ecma-01 & $\mathrm{C} 2$ & $\mathrm{D}$ & 1 \\
\hline $44(36)$ & $813(1090)$ & Tests for Parameter Instability and Structural Cha & Andrews & ecma-93 & $\mathrm{C} 2$ & $\mathrm{D}$ & 1 \\
\hline $45(31)$ & $811(1163)$ & A Simple Model of Herd Behavior & Banerjee & qje-92 & D8-D6 & $\mathrm{T}$ & 1 \\
\hline $46(173)$ & $810(442)$ & Estimating Trade Flows & Helpman et al. & qje-08 & $\mathrm{F} 1$ & $\mathrm{D}$ & 1 \\
\hline $47(38)$ & $788(1081)$ & Protection for Sale & Grossman ; Helpman & aer-94 & F1-D7 & $\mathrm{T}$ & 0.50 \\
\hline $48(42)$ & $767(1029)$ & Finance and Growth & King ; Levine & qje-93 & O1 & $\mathrm{D}$ & 1 \\
\hline $49(32)$ & $764(1142)$ & Golden Eggs and Hyperbolic Discounting & Laibson & qje-97 & D9-G1 & $\mathrm{D}$ & 1 \\
\hline $50(48)$ & $757(948)$ & Does Trade Cause Growth & Frankel ; Romer & aer-99 & $\mathrm{F} 4-\mathrm{O} 4$ & $\mathrm{D}$ & 1 \\
\hline $51(37)$ & $756(1084)$ & Changes in Relative Wages, 1963-1987 & Katz ; Murphy & qje-92 & $\mathrm{J} 3$ & $\mathrm{D}$ & 1 \\
\hline $52(62)$ & $751(755)$ & Understanding Social Preferences with Simple Tests & Charness ; Rabin & qje-02 & D7 & $\mathrm{E}$ & 1 \\
\hline $53(1211)$ & $743(126)$ & The Oregon Health Insurance Experiment & Finkelstein et al. & qje-12 & H7-I3 & $\mathrm{D}$ & 0.13 \\
\hline $54(49)$ & $743(915)$ & Automobile Prices in Market Equilibrium & Berry et al. & ecma-95 & L1-L6 & $\mathrm{D}$ & 1 \\
\hline $55(65)$ & $739(743)$ & Reversal of Fortune & Acemoglu et al. & qje-02 & D3-O1 & $\mathrm{D}$ & 1 \\
\hline $56(35)$ & $736(1101)$ & Africa's Growth Tragedy & Easterly ; Levine & qje-97 & O5-J1 & $\mathrm{D}$ & 1 \\
\hline $57(326)$ & $735(311)$ & Not All Oil Price Shocks Are Alike & Kilian & $\operatorname{aer}(\mathrm{s})-09$ & E3-Q4 & $\mathrm{D}$ & 1 \\
\hline $58(90)$ & $733(617)$ & Teachers, Schools, and Academic Achievement & Rivkin et al. & ecma-05 & $\mathrm{I} 2$ & $\mathrm{D}$ & 0.67 \\
\hline $59(518)$ & $722(231)$ & Beyond Markets and States & Ostrom & aer-10 & D0-O1-Q2 & $\mathrm{T}$ & 1 \\
\hline $60(75)$ & $703(707)$ & The Regulation of Entry & Djankov et al. & qje-02 & L1-M1 & $\mathrm{D}$ & 0.25 \\
\hline $61(54)$ & $696(872)$ & By Force of Habit & Campbell ; Cochrane & jpe-99 & G1 & $\mathrm{T}$ & 1 \\
\hline $62(93)$ & $695(612)$ & Are Emily and Greg More Employable than Lakisha an & Bertrand ; Mullainathan & aer-04 & J1-J7 & $\mathrm{D}$ & 1 \\
\hline $63(179)$ & $691(435)$ & Experimental Analysis of Neighborhood Effects & Kling et al. & ecma-07 & I3-R2-R3 & $\mathrm{D}$ & 1 \\
\hline $64(50)$ & $680(912)$ & Corruption & Shleifer ; Vishny & q.je-93 & D7-K4 & $\mathrm{T}$ & 1 \\
\hline $65(381)$ & $664(281)$ & Misallocation and Manufacturing TFP in China and I & Hsieh ; Klenow & qje-09 & $\mathrm{L} 6-\mathrm{O} 4$ & $\mathrm{D}$ & 1 \\
\hline $66(51)$ & $663(909)$ & Productivity Growth, Technical Progress, and Effic & Fare et al. & aer-94 & $\mathrm{O} 4$ & $\mathrm{D}$ & 0.25 \\
\hline $67(52)$ & $661(886)$ & A Simple Estimator of Cointegrating Vectors in Hig & Stock ; Watson & ecma-93 & $\mathrm{C} 3-\mathrm{E} 4$ & $\mathrm{D}$ & 1 \\
\hline $68(45)$ & $654(978)$ & Credit Cycles & Kiyotaki ; Moore & jpe-97 & E5-E3-E2 & $\mathrm{T}$ & 0.50 \\
\hline $69(3742)$ & $653(30)$ & Do Consumers Respond to Marginal or Average Price & Ito & aer-14 & D1-L9 & $\mathrm{D}$ & 1 \\
\hline $70(254)$ & $651(355)$ & Market Size, Trade, and Productivity & Melitz ; Ottaviano & restud-08 & $\mathrm{F} 1$ & $\mathrm{~T}$ & 0.50 \\
\hline
\end{tabular}

The comparison of Tables 3 and 10 shows that our normalization leads to an increase in the number of AER $(+3)$ and QJE $(+2)$ articles in the top-70. On the other hand ECMA $(-2)$ and JPE $(-3)$ have a few less articles. The normalization also leads to a ranking that contains more recent articles. Indeed, all the 14 articles that are in red date are published after 2002. ${ }^{13}$ Consequently, the age of articles is more evenly distributed in the list of Table 10 than in the list of Table 3. More precisely, among the articles appearing in Table 3, 35 were published in the period 1991-1995, 24 in 1996-2000, and 11 in 2001-2005. Among those in Table 10, 20 were published in 1991-1995, 11 in 1996-2000, 13 in 2001-2005, 13 in 2006-2010, and 13 in 2011-2015. Given this evidence, and because there is no reason to believe that the quality of articles in

\footnotetext{
${ }^{13}$ There are even two articles published in 2014: "A Macroeconomic Model with a Financial Sector" by Brunnermeier and Sannikov, and "Do Consumers Respond to Marginal or Average Price" by Ito, both published in AER.
} 
the top-5 has changed between 1991 and 2015, it seems preferable to measure academic influence through normalized citations.

\section{$6 \quad$ Lists by JEL codes}

Many articles have several JEL codes (at the two digit level). In our data, the majority of articles (75\%) use less than 3 codes, but $10 \%$ of them have more than 5 codes. In the analysis of this section we only use JEL codes at the letter level. For example, if an article has C70, C72, and D63 as JEL codes, then at the letter level it has two JEL codes: C (with a weight 0.66) and D (with a weight 0.33). At this letter level, $90 \%$ of the articles have at most two JEL codes.

In the left panel of Table 11 we present the usage of JEL codes (in percentage) for our different time periods. ${ }^{14}$ The right panel shows the average of the normalized citation per subperiod and JEL code. To find the meaning of a JEL code one can click on it (in the pdf version of this report).

Table 11: JEL codes:

\begin{tabular}{ccc|cccccc}
\multicolumn{1}{c}{ Usage (pct) } \\
\hline \hline & rank & All & $91-95$ & $96-00$ & $01-05$ & $06-10$ & $11-15$ \\
\hline $\mathrm{D}$ & 1 & 26.5 & 24.6 & 23.7 & 25.4 & 29.3 & 29.0 \\
$\mathrm{C}$ & 2 & 13.0 & 14.0 & 14.0 & 14.0 & 12.6 & 10.5 \\
$\mathrm{~J}$ & 3 & 10.6 & 10.8 & 11.8 & 10.5 & 10.0 & 9.9 \\
$\mathrm{E}$ & 4 & 8.4 & 11.2 & 8.5 & 7.7 & 7.1 & 7.5 \\
$\mathrm{G}$ & 5 & 7.2 & 7.4 & 8.0 & 7.8 & 5.6 & 7.2 \\
$\mathrm{~L}$ & 6 & 6.7 & 6.5 & 6.0 & 6.9 & 6.5 & 7.2 \\
$\mathrm{O}$ & 7 & 5.5 & 5.8 & 7.0 & 5.1 & 5.2 & 4.9 \\
$\mathrm{~F}$ & 8 & 4.7 & 5.2 & 4.3 & 5.3 & 4.6 & 4.1 \\
$\mathrm{H}$ & 9 & 3.9 & 3.4 & 3.9 & 4.3 & 4.0 & 4.1 \\
$\mathrm{I}$ & 10 & 3.7 & 2.3 & 3.1 & 3.7 & 4.5 & 4.8 \\
$\mathrm{R}$ & 11 & 1.8 & 1.2 & 1.3 & 2.1 & 1.8 & 2.6 \\
$\mathrm{Q}$ & 12 & 1.8 & 1.9 & 2.4 & 1.4 & 1.2 & 2.2 \\
$\mathrm{~N}$ & 13 & 1.6 & 1.4 & 1.3 & 1.8 & 1.5 & 1.8 \\
$\mathrm{~K}$ & 14 & 1.3 & 1.1 & 1.3 & 1.1 & 1.3 & 1.7 \\
$\mathrm{M}$ & 15 & 1.3 & 1.5 & 0.9 & 1.1 & 2.1 & 1.0 \\
$\mathrm{Z}$ & 16 & 0.8 & 0.1 & 0.4 & 0.7 & 1.7 & 1.2 \\
$\mathrm{P}$ & 17 & 0.7 & 0.8 & 1.0 & 0.7 & 0.7 & 0.4 \\
$\mathrm{~A}$ & 18 & 0.4 & 0.7 & 0.5 & 0.4 & 0.2 & 0.1 \\
$\mathrm{~B}$ & 19 & 0.2 & 0.2 & 0.7 & 0.1 & 0.1 & 0.1 \\
\hline
\end{tabular}

\begin{tabular}{|c|c|c|c|c|c|c|c|}
\hline & rank & All & 91-95 & $96-00$ & 01-05 & 06-10 & 11-14 \\
\hline $\mathrm{O}$ & 1 & 73.4 & $\mid 156.7$ & 74.9 & 65.7 & 51.5 & 42.8 \\
\hline $\mathrm{F}$ & 2 & 72.8 & 63.2 & 64.0 & 94.3 & 77.7 & 60.5 \\
\hline $\mathrm{R}$ & 3 & 64.2 & 129.5 & 100.2 & 58.7 & 57.5 & 41.0 \\
\hline C & 4 & 62.6 & 89.0 & 74.8 & 59.9 & 51.9 & 40.0 \\
\hline G & 5 & 59.5 & 68.1 & 83.1 & 64.7 & 47.8 & 40.7 \\
\hline $\mathrm{J}$ & 6 & 58.2 & 75.3 & 61.1 & 61.3 & 51.4 & 45.8 \\
\hline $\mathrm{E}$ & 7 & 56.4 & 51.8 & 60.8 & 53.3 & 60.1 & 57.7 \\
\hline I & 8 & 53.1 & 52.7 & 61.8 & 56.8 & 54.2 & 45.1 \\
\hline Q & 9 & 52.6 & 66.8 & 53.5 & 33.4 & 51.6 & 55.7 \\
\hline $\mathrm{D}$ & 10 & 49.0 & 59.0 & 51.5 & 49.2 & 50.5 & 38.6 \\
\hline $\mathrm{P}$ & 11 & 47.5 & 40.2 & 57.1 & 64.6 & 37.9 & 31.0 \\
\hline Z & 12 & 46.5 & 41.0 & 101.3 & 49.3 & 52.2 & 31.9 \\
\hline $\mathrm{L}$ & 13 & 46.4 & 48.2 & 49.3 & 46.9 & 49.7 & 40.1 \\
\hline K & 14 & 43.3 & 48.0 & 105.6 & 46.8 & 35.5 & 20.0 \\
\hline M & 15 & 42.5 & 52.8 & 46.4 & 44.0 & 44.9 & 26.0 \\
\hline $\mathrm{N}$ & 16 & 42.3 & 51.6 & 18.1 & 42.9 & 41.9 & 49.6 \\
\hline $\mathrm{H}$ & 17 & 38.7 & 39.6 & 46.7 & 34.5 & 40.2 & 35.9 \\
\hline A & 18 & 38.7 & 35.1 & 49.4 & 35.7 & 50.7 & 24.1 \\
\hline B & 19 & 29.9 & 9.5 & 29.3 & 84.0 & 17.4 & 13.9 \\
\hline
\end{tabular}

The most popular code is D (Microeconomics) with $26.5 \%$ of all JEL codes being in that category. In addition, this field of economics is getting more and more popular as the percentage of the $\mathrm{D}$ code has climbed from $24.6 \%$ in $91-95$ to $29.0 \%$ in $11-15$. However, in terms of citations it is only ranked 10 th with 39.4 citations on average. The JEL code with the highest average citation is O (Economic Development, Innovation, Technological Change, and Growth). Only 5.5\% of the JEL codes are in this category but they receive on average 69.8 citations (with a stunning 215.5 average in 91-95). Codes F (International Economics) and R (Urban, Rural, Regional, Real Estate, and Transportation Economics) have also a higher rank in terms of average citations than in terms of usage.

The fact that not all JEL codes receive the same amount of citations means that in the list of Tables 3 and 10 some fields are over-represented compared to their sizes. The simplest way to give each field a fair chance is to present lists by JEL codes. For all lists presented in this section the articles published in 2015 are excluded as for them it is impossible to normalize their citations.

\footnotetext{
${ }^{14}$ Kelly and Bruestle (2011) have studied in more detail the evolution of JEL codes usage from 1970 to 2007.
} 


\subsection{Code D: Microeconomics}

Table 12 reports the number of published articles with at least one JEL code D, for each journal and both the full period and our five subperiods. Publications in the AER and ECMA are decomposed in regular and shorter publications. This table should be compared with Table 1. The JEL code D is used very frequently.

Table 12: Nb of articles with at least one JEL code D

\begin{tabular}{|c|c|c|c|c|c|c|}
\hline & All years & 91-95 & $96-00$ & 01-05 & 06-10 & $11-15$ \\
\hline $\begin{array}{l}\operatorname{aer}(\mathrm{r}) \\
\operatorname{aer}(\mathrm{s})\end{array}$ & $\begin{array}{l}699(100) \\
(23.1) \\
280(100) \\
(9.3)\end{array}$ & $\begin{array}{l}88(12.6) \\
(17.7) \\
44(15.7) \\
(8.8)\end{array}$ & $\begin{array}{l}70(10.0) \\
(16.2) \\
35(12.5) \\
(8.1)\end{array}$ & $\begin{array}{l}104(14.9) \\
(17.7) \\
59(21.1) \\
(10.1)\end{array}$ & $\begin{array}{l}184(26.3) \\
(28.3) \\
59(21.1) \\
(9.1)\end{array}$ & $\begin{array}{l}253(36.2) \\
(29.7) \\
83(29.6) \\
(9.7)\end{array}$ \\
\hline aer (all) & $\begin{array}{l}979(100) \\
(32.4) \\
\end{array}$ & $\begin{array}{l}132(13.5) \\
(26.5)\end{array}$ & $\begin{array}{l}105(10.7) \\
(24.3) \\
\end{array}$ & $\begin{array}{l}163(16.6) \\
(27.8) \\
\end{array}$ & $\begin{array}{l}243(24.8) \\
(37.4) \\
\end{array}$ & $\begin{array}{l}336(34.3) \\
(39.4)\end{array}$ \\
\hline $\begin{array}{l}\text { ecma }(r) \\
\text { ecma }(s)\end{array}$ & $\begin{array}{l}543(100) \\
(18.0) \\
144(100) \\
(4.8)\end{array}$ & $\begin{array}{l}109(20.1) \\
(21.9) \\
18(12.5) \\
(3.6)\end{array}$ & $\begin{array}{l}75(13.8) \\
(17.4) \\
25(17.4) \\
(5.8)\end{array}$ & $\begin{array}{l}105(19.3) \\
(17.9) \\
43(29.9) \\
(7.3)\end{array}$ & $\begin{array}{l}114(21.0) \\
(17.5) \\
31(21.5) \\
(4.8)\end{array}$ & $\begin{array}{l}140(25.8) \\
(16.4) \\
27(18.8) \\
(3.2)\end{array}$ \\
\hline ecma (all) & $\begin{array}{l}687(100) \\
(22.7) \\
\end{array}$ & $\begin{array}{l}127(18.5) \\
(25.5)\end{array}$ & $\begin{array}{l}100(14.6) \\
(23.1) \\
\end{array}$ & $\begin{array}{l}148(21.5) \\
(25.2) \\
\end{array}$ & $\begin{array}{l}145(21.1) \\
(22.3) \\
\end{array}$ & $\begin{array}{l}167(24.3) \\
(19.6)\end{array}$ \\
\hline jpe & $\begin{array}{l}433(100) \\
(14.3)\end{array}$ & $\begin{array}{l}98(22.6) \\
(19.7)\end{array}$ & $\begin{array}{l}86(19.9) \\
(19.9)\end{array}$ & $\begin{array}{l}100(23.1) \\
(17.0)\end{array}$ & $\begin{array}{l}65(15.0) \\
(10.0)\end{array}$ & $\begin{array}{l}84(19.4) \\
(9.8)\end{array}$ \\
\hline qje & $\begin{array}{l}350(100) \\
(11.6)\end{array}$ & $\begin{array}{l}56(16.0) \\
(11.2)\end{array}$ & $\begin{array}{l}58(16.6) \\
(13.4)\end{array}$ & $\begin{array}{l}74(21.1) \\
(12.6)\end{array}$ & $\begin{array}{l}71(20.3) \\
(10.9)\end{array}$ & $\begin{array}{l}91(26.0) \\
(10.7)\end{array}$ \\
\hline restud & $\begin{array}{l}571(100) \\
(18.9)\end{array}$ & $\begin{array}{l}85(14.9) \\
(17.1)\end{array}$ & $\begin{array}{l}83(14.5) \\
(19.2)\end{array}$ & $\begin{array}{l}102(17.9) \\
(17.4)\end{array}$ & $\begin{array}{l}126(22.1) \\
(19.4)\end{array}$ & $\begin{array}{l}175(30.6) \\
(20.5)\end{array}$ \\
\hline All & $\begin{array}{l}3,020(100) \\
(100)\end{array}$ & $\begin{array}{l}498(16.5) \\
(100)\end{array}$ & $\begin{array}{l}432(14.3) \\
(100)\end{array}$ & $\begin{array}{l}587(19.4) \\
(100)\end{array}$ & $\begin{array}{l}650(21.5) \\
(100)\end{array}$ & $\begin{array}{l}853(28.2) \\
(100)\end{array}$ \\
\hline
\end{tabular}

Table 12 shows that out of 6,816 articles 3,020 have at least one JEL code D. It appears in all journals but slightly less in QJE and slightly more in RESTUD. Table 13 summarizes the distributions of year-normalized citations for JEL code D per journal (year 2015 is excluded here). They should be compared to the ones of Table 9.

Table 13: Year-normalized citations for JEL code D

\begin{tabular}{lrllllllllllll}
\hline \hline & $\mathrm{N}$ & mean & $\sigma$ & min & p5 & p10 & p25 & p50 & p75 & p90 & p95 & p99 & max \\
\hline aer (r) & 631 & 53.32 & 63.16 & 0 & 3 & 7 & 16 & 35 & 66 & 126 & 157 & 300 & 546 \\
aer (s) & 271 & 43.04 & 76.37 & 0 & 2 & 5 & 9 & 23 & 47 & 100 & 137 & 300 & 959 \\
\hline aer (all) & 902 & 50.23 & 67.52 & 0 & 3 & 6 & 13 & 30 & 60 & 120 & 152 & 300 & 959 \\
\hline ecma (r) & 517 & 50.93 & 58.14 & 0 & 5 & 7 & 16 & 31 & 65 & 109 & 168 & 299 & 523 \\
ecma (s) & 136 & 37.81 & 53.93 & 0 & 2 & 3 & 10 & 24 & 43 & 77 & 119 & 318 & 393 \\
\hline ecma (all) & 653 & 48.20 & 57.49 & 0 & 4 & 7 & 15 & 29 & 61 & 103 & 164 & 308 & 523 \\
\hline jpe & 417 & 44.28 & 66.42 & 0 & 3 & 5 & 12 & 26 & 53 & 96 & 147 & 216 & 958 \\
qje & 333 & 82.43 & 132.03 & 0 & 5 & 8 & 17 & 41 & 93 & 193 & 255 & 811 & 1,231 \\
restud & 545 & 31.20 & 37.86 & 0 & 2 & 4 & 8 & 18 & 40 & 73 & 99 & 187 & 361 \\
\hline All & 2,850 & 49.02 & 73.09 & 0 & 3 & 6 & 12 & 28 & 58 & 112 & 160 & 321 & 1,231 \\
\hline
\end{tabular}

Table 14 lists the top 50 articles with at least one JEL code D. The articles are ranked according to their year-normalized number of citations weighted by the percentage of JEL code D among their JEL codes. The number in parentheses is the number of weighted citations (i.e., without the normalization per year). 
For example, the article "Corruption and Growth" is ranked first both after the normalization (column $\widetilde{R}$ ) and before the normalization $(\mathrm{R})$. It received 1,516 citations which are normalized to 1,231 . As indicated by the column labeled 'pct' all the JEL codes of this article are in the D category. Regarding the article "A Theory of Fairness, Competition, and Cooperation", only 50\% of its JEL codes are in the D category. Therefore its total number of citations (either normalized or not) is divided by two in this table. Finally, articles which are ranked below 50 after the normalization but above 50 before are in red.

Table 14: Top 50 articles for $T=1991-2014$ Code D, normalized per year

\begin{tabular}{|c|c|c|c|c|c|c|c|}
\hline$\widetilde{R}(\mathrm{R})$ & $\widetilde{C_{i}}\left(C_{i}\right)$ & Title & Authors & Journal & pct & Type & USA \\
\hline $1(1)$ & $1231(1516)$ & Corruption and Growth & Mauro & qje-95 & $100 \%$ & $\mathrm{D}$ & 1 \\
\hline $2(2)$ & $963(1406)$ & Loss Aversion in Riskless Choice & Tversky ; Kahneman & q.je-91 & $100 \%$ & $\mathrm{E}$ & 1 \\
\hline $3(6)$ & $959(964)$ & Risk Aversion and Incentive Effects & Holt ; Laury & $\operatorname{aer}(\mathrm{s})-02$ & $100 \%$ & $\mathrm{E}$ & 1 \\
\hline $4(3)$ & $958(1374)$ & A Theory of Fads, Fashion, Custom, and Cultural Ch & Bikhchandani et al. & jpe-92 & $100 \%$ & $\mathrm{~T}$ & 1 \\
\hline $5(5)$ & $908(1137)$ & A Theory of Fairness, Competition, and Cooperation & Fehr ; Schmidt & qje-99 & $50 \%$ & $\mathrm{~T}$ & 0 \\
\hline $6(4)$ & $811(1163)$ & A Simple Model of Herd Behavior & Banerjee & qje-92 & $100 \%$ & $\mathrm{~T}$ & 1 \\
\hline $7(7)$ & $751(755)$ & Understanding Social Preferences with Simple Tests & Charness ; Rabin & qje-02 & $100 \%$ & $\mathrm{E}$ & 1 \\
\hline $8(9)$ & $546(663)$ & $\mathrm{ERC}$ & Bolton ; Ockenfels & aer-00 & $50 \%$ & $\mathrm{~T}$ & 0.50 \\
\hline $9(1128)$ & $523(24)$ & Dynamic Mechanism Design & Pavan et al. & ecma-14 & $100 \%$ & $\mathrm{~T}$ & 1 \\
\hline $10(8)$ & $507(681)$ & Incorporating Fairness into Game Theory and Econom & Rabin & aer-93 & $50 \%$ & $\mathrm{~T}$ & 1 \\
\hline $11(11)$ & $481(603)$ & Doing It Now or Later & O'Donoghue ; Rabin & aer-99 & $100 \%$ & $\mathrm{~T}$ & 1 \\
\hline $12(32)$ & $468(315)$ & Incentives and Prosocial Behavior & Benabou ; Tirole & aer-06 & $75 \%$ & $\mathrm{~T}$ & 0.25 \\
\hline $13(35)$ & $465(313)$ & A Model of Reference-Dependent Preferences & Koszegi ; Rabin & qje-06 & $100 \%$ & $\mathrm{~T}$ & 1 \\
\hline $14(10)$ & $441(659)$ & Formal and Real Authority in Organizations & Aghion ; Tirole & jpe-97 & $100 \%$ & $\mathrm{~T}$ & 0 \\
\hline $15(197)$ & $400(128)$ & Are Risk Aversion and Impatience Related to Cognit & Dohmen et al. & $\operatorname{aer}(\mathrm{s})-10$ & $100 \%$ & $\mathrm{E}$ & 0.25 \\
\hline $16(14)$ & $394(541)$ & Protection for Sale & Grossman ; Helpman & aer-94 & $50 \%$ & $\mathrm{~T}$ & 0.50 \\
\hline $17(22)$ & $393(395)$ & Giving According to GARP & Andreoni ; Miller & ecma(s)-02 & $100 \%$ & $\mathrm{E}$ & 1 \\
\hline $18(67)$ & $392(247)$ & Do Women Shy Away from Competition & Niederle ; Vesterlund & qje-07 & $67 \%$ & $\mathrm{E}$ & 0.50 \\
\hline $19(12)$ & $384(551)$ & Anomalies in Intertemporal Choice & Loewenstein ; Prelec & qje-92 & $100 \%$ & $\mathrm{D}$ & 1 \\
\hline $20(15)$ & $374(536)$ & Entry, Exit, and Firm Dynamics in Long Run Equilib & Hopenhayn & ecma-92 & $100 \%$ & $\mathrm{~T}$ & 1 \\
\hline $21(13)$ & $363(542)$ & Back to Bentham & Kahneman et al. & qje-97 & $100 \%$ & $\mathrm{D}$ & 0.67 \\
\hline $22(23)$ & $361(391)$ & Intrinsic and Extrinsic Motivation & Benabou ; Tirole & restud-03 & $100 \%$ & $\mathrm{~T}$ & 0.75 \\
\hline $23(1419)$ & $348(16)$ & Risk Shocks & Christiano et al. & aer-14 & $40 \%$ & $\mathrm{D}$ & 0.33 \\
\hline $24(19)$ & $344(417)$ & Participation in Heterogeneous Communities & Alesina ; La Ferrara & qje-00 & $100 \%$ & $\mathrm{D}$ & 0.50 \\
\hline $25(16)$ & $340(456)$ & Corruption & Shleifer ; Vishny & qje-93 & $50 \%$ & $\mathrm{~T}$ & 1 \\
\hline $26(49)$ & $331(279)$ & A Smooth Model of Decision Making under Ambiguity & Klibanoff et al. & ecma-05 & $100 \%$ & $\mathrm{~T}$ & 0.33 \\
\hline $27(51)$ & $330(278)$ & Neighbors as Negatives & Luttmer & qje-05 & $67 \%$ & $\mathrm{D}$ & 1 \\
\hline $28(17)$ & $321(431)$ & Allocative Efficiency of Markets with Zero-Intelli & Gode ; Sunder & jpe-93 & $100 \%$ & $\mathrm{E}$ & 1 \\
\hline $29(28)$ & $321(348)$ & "Coherent Arbitrariness" & Ariely et al. & qje-03 & $100 \%$ & $\mathrm{E}$ & 1 \\
\hline $30(25)$ & $318(386)$ & Risk Aversion and Expected-Utility Theory & Rabin & ecma(s)-00 & $100 \%$ & $\mathrm{~T}$ & 1 \\
\hline $31(129)$ & $317(173)$ & Eliciting Risk and Time Preferences & Andersen et al. & ecma-08 & $100 \%$ & $\mathrm{E}$ & 0.75 \\
\hline $32(18)$ & $308(418)$ & The Probability Weighting Function & & ecma-98 & $100 \%$ & $\mathrm{D}$ & 1 \\
\hline $33(380)$ & $306(79)$ & Depression Babies & Malmendier ; Nagel & qje-11 & $67 \%$ & $\mathrm{D}$ & 1 \\
\hline $34(38)$ & $300(302)$ & Last-Minute Bidding and the Rules for Ending Secon & Roth ; Ockenfels & $\operatorname{aer}(\mathrm{s})-02$ & $100 \%$ & $\mathrm{~T}$ & 0.50 \\
\hline $34(38)$ & $300(302)$ & Social Value of Public Information & Morris ; Shin & aer-02 & $100 \%$ & $\mathrm{~T}$ & 0.50 \\
\hline $36(299)$ & $299(96)$ & Social Preferences, Beliefs, and the Dynamics of F & Fischbacher ; Gachter & $\operatorname{aer}(\mathrm{s})-10$ & $50 \%$ & $\mathrm{E}$ & 0 \\
\hline $37(94)$ & $299(201)$ & Ambiguity Aversion, Robustness, and the Variationa & Maccheroni et al. & ecma-06 & $100 \%$ & $\mathrm{~T}$ & 0.33 \\
\hline $38(20)$ & $298(409)$ & Distributive Politics and Economic Growth & Alesina ; Rodrik & qje-94 & $50 \%$ & $\mathrm{D}$ & 1 \\
\hline $39(42)$ & $295(297)$ & Consumption over the Life Cycle & Gourinchas ; Parker & ecma-02 & $100 \%$ & $\mathrm{D}$ & 1 \\
\hline $40(24)$ & $290(390)$ & Learning, Mutation, and Long Run Equilibria in Gam & Kandori et al. & ecma-93 & $50 \%$ & $\mathrm{~T}$ & 0.67 \\
\hline $41(21)$ & $277(405)$ & Resistance to Reform & Fernandez ; Rodrik & aer-91 & $100 \%$ & $\mathrm{~T}$ & 1 \\
\hline $42(113)$ & $275(185)$ & A Dual-Self Model of Impulse Control & Fudenberg ; Levine & aer-06 & $100 \%$ & $\mathrm{E}$ & 1 \\
\hline $43(27)$ & $271(372)$ & Is Inequality Harmful for Growth & Persson ; Tabellini & aer-94 & $50 \%$ & $\mathrm{D}$ & 0 \\
\hline $44(46)$ & $262(284)$ & The Economic Costs of Conflict & Abadie ; Gardeazabal & aer-03 & $100 \%$ & $\mathrm{D}$ & 0.50 \\
\hline $45(47)$ & $261(283)$ & Does Market Experience Eliminate Market Anomalies & List & qje-03 & $100 \%$ & $\mathrm{E}$ & 1 \\
\hline $46(54)$ & $259(273)$ & Temptation and Self-Control & Gul ; Pesendorfer & ecma-01 & $100 \%$ & $\mathrm{~T}$ & 1 \\
\hline $47(82)$ & $258(218)$ & Deception & Gneezy & $\operatorname{aer}(\mathrm{s})-05$ & $75 \%$ & $\mathrm{~T}$ & 1 \\
\hline $48(26)$ & $255(381)$ & Golden Eggs and Hyperbolic Discounting & Laibson & qje-97 & $33 \%$ & $\mathrm{D}$ & 1 \\
\hline $49(81)$ & $250(220)$ & Inequality Aversion, Efficiency, and Maximin Prefe & Engelmann ; Strobel & aer-04 & $100 \%$ & $\mathrm{E}$ & 0 \\
\hline $50(40)$ & $248(301)$ & Economics and Identity & Akerlof ; Kranton & q.je-00 & $40 \%$ & $\mathrm{~T}$ & 1 \\
\hline
\end{tabular}




\subsection{Code C: Mathematical and Quantitative Methods}

Table 15 reports the number of published articles with at least one JEL code C, for each journal and both the full period and our five subperiods. Publications in the AER and ECMA are decomposed in regular and shorter publications. It shows that out of 6,816 articles 1,288 have at least one JEL code C.

Table 15: Nb of articles with at least one JEL code C

\begin{tabular}{|c|c|c|c|c|c|c|}
\hline & All years & 91-95 & $96-00$ & 01-05 & 06-10 & $11-15$ \\
\hline $\begin{array}{l}\operatorname{aer}(\mathrm{r}) \\
\operatorname{aer}(\mathrm{s})\end{array}$ & $\begin{array}{l}174(100) \\
(13.5) \\
54(100) \\
(4.2)\end{array}$ & $\begin{array}{l}25(14.4) \\
(10.5) \\
7(13.0) \\
(2.9)\end{array}$ & $\begin{array}{l}15(8.6) \\
(6.9) \\
5(9.3) \\
(2.3)\end{array}$ & $\begin{array}{l}21(12.1) \\
(7.9) \\
9(16.7) \\
(3.4)\end{array}$ & $\begin{array}{l}53(30.5) \\
(20.1) \\
10(18.5) \\
(3.8)\end{array}$ & $\begin{array}{l}60(34.5) \\
(19.9) \\
23(42.6) \\
(7.6)\end{array}$ \\
\hline aer (all) & $\begin{array}{l}228(100) \\
(17.7) \\
\end{array}$ & $\begin{array}{l}32(14.0) \\
(13.4) \\
\end{array}$ & $\begin{array}{l}20(8.8) \\
(9.2) \\
\end{array}$ & $\begin{array}{l}30(13.2) \\
(11.3) \\
\end{array}$ & $\begin{array}{l}63(27.6) \\
(23.9) \\
\end{array}$ & $\begin{array}{l}83(36.4) \\
(27.5) \\
\end{array}$ \\
\hline $\begin{array}{l}\text { ecma }(r) \\
\text { ecma }(s)\end{array}$ & $\begin{array}{l}562(100) \\
(43.6) \\
204(100) \\
(15.8)\end{array}$ & $\begin{array}{l}119(21.2) \\
(49.8) \\
30(14.7) \\
(12.6)\end{array}$ & $\begin{array}{l}111(19.8) \\
(51.2) \\
32(15.7) \\
(14.7)\end{array}$ & $\begin{array}{l}130(23.1) \\
(48.9) \\
56(27.5) \\
(21.1)\end{array}$ & $\begin{array}{l}98(17.4) \\
(37.1) \\
44(21.6) \\
(16.7)\end{array}$ & $\begin{array}{l}104(18.5) \\
(34.4) \\
42(20.6) \\
(13.9)\end{array}$ \\
\hline ecma (all) & $\begin{array}{l}766(100) \\
(59.5) \\
\end{array}$ & $\begin{array}{l}149(19.5) \\
(62.3)\end{array}$ & $\begin{array}{l}143(18.7) \\
(65.9)\end{array}$ & $\begin{array}{l}186(24.3) \\
(69.9) \\
\end{array}$ & $\begin{array}{l}142(18.5) \\
(53.8)\end{array}$ & $\begin{array}{l}146(19.1) \\
(48.3)\end{array}$ \\
\hline jpe & $\begin{array}{l}41(100) \\
(3.2)\end{array}$ & $\begin{array}{l}4(9.8) \\
(1.7)\end{array}$ & $\begin{array}{l}5(12.2) \\
(2.3)\end{array}$ & $\begin{array}{l}10(24.4) \\
(3.8)\end{array}$ & $\begin{array}{l}12(29.3) \\
(4.5)\end{array}$ & $\begin{array}{l}10(24.4) \\
(3.3)\end{array}$ \\
\hline qje & $\begin{array}{l}37(100) \\
(2.9)\end{array}$ & $\begin{array}{l}6(16.2) \\
(2.5)\end{array}$ & $\begin{array}{l}10(27.0) \\
(4.6)\end{array}$ & $\begin{array}{l}6(16.2) \\
(2.3)\end{array}$ & $\begin{array}{l}6(16.2) \\
(2.3)\end{array}$ & $\begin{array}{l}9(24.3) \\
(3.0)\end{array}$ \\
\hline restud & $\begin{array}{l}216(100) \\
(16.8)\end{array}$ & $\begin{array}{l}48(22.2) \\
(20.1)\end{array}$ & $\begin{array}{l}39(18.1) \\
(18.0)\end{array}$ & $\begin{array}{l}34(15.7) \\
(12.8)\end{array}$ & $\begin{array}{l}41(19.0) \\
(15.5)\end{array}$ & $\begin{array}{l}54(25.0) \\
(17.9)\end{array}$ \\
\hline All & $\begin{array}{l}1,288(100) \\
(100)\end{array}$ & $\begin{array}{l}239(18.6) \\
(100)\end{array}$ & $\begin{array}{l}217(16.8) \\
(100)\end{array}$ & $\begin{array}{l}266(20.7) \\
(100)\end{array}$ & $\begin{array}{l}264(20.5) \\
(100)\end{array}$ & $\begin{array}{l}302(23.4) \\
(100)\end{array}$ \\
\hline
\end{tabular}

This table should be compared with Table 1. ECMA publishes the majority of the articles with a JEL code C: almost $60 \%$ over the whole period. The AER is second but compared to Table 1 code $\mathrm{C}$ is underrepresented. For RESTUD the percentages for code $\mathrm{C}$ articles are similar to the percentages for all articles. Finally, for JPE and QJE this is much less present: $3.2 \%$ and $2.9 \%$ respectively whereas these journals have published $15 \%$ and $15.4 \%$ of all articles respectively.

Table 16 summarizes the distributions of year-normalized citations for JEL code C per journal (year 2015 is excluded here). They should be compared to the ones of Table 9.

Table 16: Year-normalized citations for JEL code C

\begin{tabular}{lrlcrrrrrrrrrr}
\hline \hline & $\mathrm{N}$ & mean & $\sigma$ & min & $\mathrm{p} 5$ & $\mathrm{p} 10$ & $\mathrm{p} 25$ & $\mathrm{p} 50$ & $\mathrm{p} 75$ & $\mathrm{p} 90$ & $\mathrm{p} 95$ & $\mathrm{p} 99$ & $\mathrm{max}$ \\
\hline aer (r) & 159 & 48.56 & 78.63 & 0 & 4 & 7 & 13 & 24 & 54 & 101 & 157 & 507 & 546 \\
aer (s) & 52 & 53.40 & 64.95 & 0 & 2 & 5 & 10 & 39 & 73 & 104 & 197 & 357 & 357 \\
\hline aer (all) & 211 & 49.75 & 75.37 & 0 & 4 & 6 & 12 & 25 & 55 & 101 & 169 & 440 & 546 \\
\hline ecma (r) & 542 & 75.31 & 137.59 & 0 & 6 & 9 & 16 & 39 & 82 & 162 & 234 & 837 & 1,543 \\
ecma (s) & 192 & 51.74 & 77.80 & 0 & 3 & 6 & 14 & 27 & 57 & 106 & 182 & 582 & 613 \\
\hline ecma (all) & 734 & 69.14 & 125.13 & 0 & 5 & 8 & 16 & 35 & 75 & 141 & 218 & 813 & 1,543 \\
\hline jpe & 39 & 39.54 & 42.61 & 2 & 3 & 5 & 11 & 34 & 49 & 95 & 129 & 229 & 229 \\
qje & 35 & 90.84 & 177.34 & 5 & 6 & 8 & 12 & 31 & 70 & 206 & 564 & 908 & 908 \\
restud & 207 & 51.92 & 133.73 & 0 & 2 & 3 & 9 & 20 & 43 & 102 & 169 & 486 & 1,468 \\
\hline All & 1,226 & 62.57 & 119.97 & 0 & 4 & 6 & 13 & 30 & 65 & 126 & 200 & 582 & 1,543 \\
\hline
\end{tabular}


Table 17 lists the top 50 articles with at least one JEL code C. See for a precise definition of the different variables Section 6.1.

Table 17: Top 50 articles for $T=1991-2014$ Code C, normalized per year

\begin{tabular}{|c|c|c|c|c|c|c|c|}
\hline$\widetilde{R}(\mathrm{R})$ & $\widetilde{C_{i}}\left(C_{i}\right)$ & Title & Authors & Journal & pct & Type & USA \\
\hline $1(1)$ & $1543(2252)$ & Estimation and Hypothesis Testing of Cointegration & Johansen & ecma-91 & $100 \%$ & $\mathrm{D}$ & 0 \\
\hline $2(2)$ & $1468(2143)$ & Some Tests of Specification for Panel Data & Arellano ; Bond & restud-91 & $50 \%$ & $\mathrm{D}$ & 0 \\
\hline $3(3)$ & $1237(1850)$ & Instrumental Variables Regression with Weak Instru & Staiger ; Stock & ecma-97 & $100 \%$ & $\mathrm{D}$ & 1 \\
\hline $4(4)$ & $1118(1430)$ & Efficient Tests for an Autoregressive Unit Root & Elliott et al. & ecma-96 & $100 \%$ & $\mathrm{D}$ & 1 \\
\hline $5(8)$ & $908(1137)$ & A Theory of Fairness, Competition, and Cooperation & Fehr ; Schmidt & qje-99 & $50 \%$ & $\mathrm{~T}$ & 0 \\
\hline $6(5)$ & $880(1284)$ & Conditional Heteroskedasticity in Asset Returns & Nelson & ecma-91 & $67 \%$ & $\mathrm{D}$ & 1 \\
\hline $7(6)$ & $865(1263)$ & Heteroskedasticity and Autocorrelation Consistent & Andrews & ecma-91 & $100 \%$ & $\mathrm{D}$ & 1 \\
\hline $8(7)$ & $849(1138)$ & Identification of Endogenous Social Effects & Manski & restud-93 & $100 \%$ & $\mathrm{D}$ & 1 \\
\hline $9(8)$ & $837(1137)$ & Estimating and Testing Linear Models with Multiple & Bai ; Perron & ecma-98 & $100 \%$ & $\mathrm{D}$ & 0.50 \\
\hline $10(11)$ & $830(875)$ & Lag Length Selection and the Construction of Unit & $\mathrm{Ng}$; Perron & ecma-01 & $100 \%$ & $\mathrm{D}$ & 1 \\
\hline $11(10)$ & $813(1090)$ & Tests for Parameter Instability and Structural Cha & Andrews & ecma-93 & $100 \%$ & $\mathrm{D}$ & 1 \\
\hline $12(12)$ & $613(841)$ & Identification and Estimation of Local Average Tre & Imbens ; Angrist & ecma(s)-94 & $100 \%$ & $\mathrm{D}$ & 0.50 \\
\hline $13(31)$ & $582(392)$ & Large Sample Properties of Matching Estimators for & Abadie ; Imbens & ecma(s)-06 & $100 \%$ & $\mathrm{D}$ & 1 \\
\hline $15(15)$ & $546(663)$ & ERC & Bolton ; Ockenfels & aer-00 & $50 \%$ & $\mathrm{~T}$ & 0.50 \\
\hline $16(13)$ & $507(681)$ & Incorporating Fairness into Game Theory and Econom & Rabin & aer-93 & $50 \%$ & $\mathrm{~T}$ & 1 \\
\hline $17(37)$ & $499(336)$ & Estimation and Inference in Large Heterogeneous Pa & Pesaran & ecma-06 & $100 \%$ & $\mathrm{D}$ & 0 \\
\hline $18(14)$ & $486(667)$ & Automatic Lag Selection in Covariance Matrix Estim & Newey ; West & restud-94 & $100 \%$ & $\mathrm{D}$ & 1 \\
\hline $19(16)$ & $481(653)$ & Matching as an Econometric Evaluation Estimator & Heckman et al. & restud-98 & $100 \%$ & $\mathrm{D}$ & 1 \\
\hline $20(17)$ & $472(647)$ & Optimal Tests When a Nuisance Parameter Is Present & Andrews ; Ploberger & ecma-94 & $100 \%$ & $\mathrm{D}$ & 0.50 \\
\hline $21(18)$ & $440(598)$ & Predicting How People Play Games & Erev ; Roth & aer-98 & $100 \%$ & $\mathrm{E}$ & 0.75 \\
\hline $22(19)$ & $403(541)$ & The Evolution of Conventions & Young & ecma-93 & $100 \%$ & $\mathrm{~T}$ & 1 \\
\hline $23(38)$ & $377(332)$ & A Panic Attack on Unit Roots and Cointegration & Bai ; $\mathrm{Ng}$ & ecma-04 & $100 \%$ & $\mathrm{D}$ & 1 \\
\hline $24(260)$ & $374(63)$ & Optimal Bandwidth Choice for the Regression Discon & Imbens ; Kalyanaraman & restud-12 & $83 \%$ & $\mathrm{D}$ & 0.50 \\
\hline $25(20)$ & $372(505)$ & Stochastic Volatility & Kim et al. & restud-98 & $100 \%$ & $\mathrm{D}$ & 0.33 \\
\hline $26(33)$ & $369(389)$ & Identification and Estimation of Treatment Effects & Hahn et al. & ecma(s)-01 & $100 \%$ & $\mathrm{D}$ & 1 \\
\hline $27(24)$ & $357(457)$ & Social Distance and Other-Regarding Behavior in Di & Hoffman et al. & $\operatorname{aer}(\mathrm{s})-96$ & $100 \%$ & $\mathrm{~T}$ & 1 \\
\hline $28(34)$ & $344(373)$ & Efficient Estimation of Average Treatment Effects & Hirano et al. & ecma-03 & $100 \%$ & $\mathrm{D}$ & 1 \\
\hline $29(22)$ & $334(488)$ & Bargaining and Market Behavior in Jerusalem, Ljubl & Roth et al. & aer-91 & $100 \%$ & $\mathrm{E}$ & 0.25 \\
\hline $32(26)$ & $314(427)$ & Characterizing Selection Bias Using Experimental D & Heckman et al. & ecma-98 & $75 \%$ & $\mathrm{E}$ & 0.25 \\
\hline $33(27)$ & $308(422)$ & Monotone Comparative Statics & Milgrom ; Shannon & ecma-94 & $100 \%$ & $\mathrm{~T}$ & 1 \\
\hline $34(40)$ & $302(304)$ & Determining the Number of Factors in Approximate F & Bai ; $\mathrm{Ng}$ & ecma-02 & $50 \%$ & $\mathrm{D}$ & 1 \\
\hline $35(480)$ & $298(31)$ & Intersection Bounds & Chernozhukov et al. & ecma-13 & $100 \%$ & $\mathrm{D}$ & 0.33 \\
\hline $36(35)$ & $291(372)$ & Asymptotic Inference about Predictive Ability & West & ecma-96 & $100 \%$ & $\mathrm{D}$ & 1 \\
\hline $37(32)$ & $290(390)$ & Learning, Mutation, and Long Run Equilibria in Gam & Kandori et al. & ecma-93 & $50 \%$ & $\mathrm{~T}$ & 0.67 \\
\hline $38(46)$ & $290(255)$ & A Cognitive Hierarchy Model of Games & Camerer et al. & qje-04 & $100 \%$ & $\mathrm{E}$ & 0.67 \\
\hline $39(47)$ & $289(254)$ & Determinants of Long-Term Growth & Sala-i-Martin et al. & aer-04 & $67 \%$ & $\mathrm{D}$ & 0.17 \\
\hline $40(28)$ & $286(410)$ & An Improved Heteroskedasticity and Autocorrelation & Andrews ; Monahan & ecma(s)-92 & $100 \%$ & $\mathrm{D}$ & 1 \\
\hline $41(233)$ & $282(73)$ & The Model Confidence Set & Hansen et al. & ecma-11 & $100 \%$ & $\mathrm{D}$ & 0.67 \\
\hline $42(29)$ & $280(401)$ & Social Norms and Community Enforcement & Kandori & restud-92 & $100 \%$ & $\mathrm{~T}$ & 1 \\
\hline $43(43)$ & $272(273)$ & Maximum Likelihood Estimation of Discretely Sample & Ait-Sahalia & ecma-02 & $100 \%$ & $\mathrm{D}$ & 1 \\
\hline $44(30)$ & $270(394)$ & Optimal Inference in Cointegrated Systems & Phillips & ecma-91 & $100 \%$ & $\mathrm{D}$ & 1 \\
\hline $45(36)$ & $263(353)$ & Global Games and Equilibrium Selection & Carlsson ; van Damme & ecma-93 & $100 \%$ & $\mathrm{~T}$ & 0 \\
\hline $46(117)$ & $249(136)$ & On the Failure of the Bootstrap for Matching Estim & Abadie ; Imbens & ecma(s)-08 & $100 \%$ & $\mathrm{D}$ & 1 \\
\hline $47(60)$ & $247(208)$ & The Willingness to Pay-Willingness to Accept Gap, & Plott ; Zeiler & aer-05 & $100 \%$ & $\mathrm{E}$ & 1 \\
\hline $48(95)$ & $245(154)$ & Estimation and Confidence Regions for Parameter Se & Chernozhukov et al. & ecma-07 & $100 \%$ & $\mathrm{D}$ & 1 \\
\hline $49(39)$ & $243(305)$ & Linear Regression Limit Theory for Nonstationary P & Phillips ; Moon & ecma-99 & $100 \%$ & $\mathrm{D}$ & 0.75 \\
\hline $50(65)$ & $237(200)$ & Structural Equations, Treatment Effects, and Econo & Heckman ; Vytlacil & ecma-05 & $100 \%$ & $\mathrm{D}$ & 1 \\
\hline
\end{tabular}




\subsection{Code J: Labor and Demographic Economics}

Table 18 reports the number of published articles with at least one JEL code J, for each journal and both the full period and our five subperiods. Publications in the AER and ECMA are decomposed in regular and shorter publications. It shows that out of 6,816 articles 1,297 have at least one JEL code J.

Table 18: Nb of articles with at least one JEL code $\mathrm{J}$

\begin{tabular}{|c|c|c|c|c|c|c|}
\hline & All years & $91-95$ & $96-00$ & 01-05 & 06-10 & $11-15$ \\
\hline $\begin{array}{l}\operatorname{aer}(\mathrm{r}) \\
\operatorname{aer}(\mathrm{s})\end{array}$ & $\begin{array}{l}294(100) \\
(22.7) \\
150(100) \\
(11.6) \\
\end{array}$ & $\begin{array}{l}45(15.3) \\
(21.2) \\
25(16.7) \\
(11.8) \\
\end{array}$ & $\begin{array}{l}46(15.6) \\
(20.2) \\
14(9.3) \\
(6.1) \\
\end{array}$ & $\begin{array}{l}49(16.7) \\
(18.6) \\
37(24.7) \\
(14.1) \\
\end{array}$ & $\begin{array}{l}47(16.0) \\
(18.3) \\
32(21.3) \\
(12.5) \\
\end{array}$ & $\begin{array}{l}107(36.4) \\
(31.8) \\
42(28.0) \\
(12.5)\end{array}$ \\
\hline aer (all) & $\begin{array}{l}444(100) \\
(34.2)\end{array}$ & $\begin{array}{l}70(15.8) \\
(33.0)\end{array}$ & $\begin{array}{l}60(13.5) \\
(26.3)\end{array}$ & $\begin{array}{l}86(19.4) \\
(32.7) \\
\end{array}$ & $\begin{array}{l}79(17.8) \\
(30.7)\end{array}$ & $\begin{array}{l}149(33.6) \\
(44.2)\end{array}$ \\
\hline $\begin{array}{l}\text { ecma (r) } \\
\text { ecma (s) }\end{array}$ & $\begin{array}{l}90(100) \\
(6.9) \\
17(100) \\
(1.3) \\
\end{array}$ & $\begin{array}{l}9(10.0) \\
(4.2) \\
.(.) \\
(.) \\
\end{array}$ & $\begin{array}{l}18(20.0) \\
(7.9) \\
2(11.8) \\
(0.9) \\
\end{array}$ & $\begin{array}{l}16(17.8) \\
(6.1) \\
2(11.8) \\
(0.8) \\
\end{array}$ & $\begin{array}{l}19(21.1) \\
(7.4) \\
8(47.1) \\
(3.1) \\
\end{array}$ & $\begin{array}{l}28(31.1) \\
(8.3) \\
5(29.4) \\
(1.5) \\
\end{array}$ \\
\hline ecma (all) & $\begin{array}{l}107(100) \\
(8.2)\end{array}$ & $\begin{array}{l}9(8.4) \\
(4.2) \\
\end{array}$ & $\begin{array}{l}20(18.7) \\
(8.8)\end{array}$ & $\begin{array}{l}18(16.8) \\
(6.8) \\
\end{array}$ & $\begin{array}{l}27(25.2) \\
(10.5)\end{array}$ & $\begin{array}{l}33(30.8) \\
(9.8) \\
\end{array}$ \\
\hline $\begin{array}{l}\text { jpe } \\
\text { qje } \\
\text { restud }\end{array}$ & $\begin{array}{l}251(100) \\
(19.4) \\
301(100) \\
(23.2) \\
194(100) \\
(15.0) \\
\end{array}$ & $\begin{array}{l}44(17.5) \\
(20.8) \\
63(20.9) \\
(29.7) \\
26(13.4) \\
(12.3) \\
\end{array}$ & $\begin{array}{l}69(27.5) \\
(30.3) \\
52(17.3) \\
(22.8) \\
27(13.9) \\
(11.8) \\
\end{array}$ & $\begin{array}{l}67(26.7) \\
(25.5) \\
62(20.6) \\
(23.6) \\
30(15.5) \\
(11.4) \\
\end{array}$ & $\begin{array}{l}40(15.9) \\
(15.6) \\
63(20.9) \\
(24.5) \\
48(24.7) \\
(18.7) \\
\end{array}$ & $\begin{array}{l}31(12.4) \\
(9.2) \\
61(20.3) \\
(18.1) \\
63(32.5) \\
(18.7) \\
\end{array}$ \\
\hline All & $\begin{array}{l}1,297(100) \\
(100)\end{array}$ & $\begin{array}{l}212(16.3) \\
(100)\end{array}$ & $\begin{array}{l}228(17.6) \\
(100)\end{array}$ & $\begin{array}{l}263(20.3) \\
(100)\end{array}$ & $\begin{array}{l}257(19.8) \\
(100)\end{array}$ & $\begin{array}{l}337(26.0) \\
(100)\end{array}$ \\
\hline
\end{tabular}

This table should be compared with Table 1. If all JEL codes were equally represented in each journal, the percentages of both tables would be the same. Labor and Demographic Economics is under-represented ECMA ( $8.2 \%$ instead of $21 \%)$. On the other hand, this field is relatively more present in JPE and QJE.

Table 19 summarizes the distributions of year-normalized citations for JEL code J per journal (year 2015 is excluded here). They should be compared to the ones of Table 9.

Table 19: Year-normalized citations for JEL code J

\begin{tabular}{lrrrrrrrrrrrrr}
\hline \hline & $\mathrm{N}$ & mean & $\sigma$ & min & $\mathrm{p} 5$ & $\mathrm{p} 10$ & $\mathrm{p} 25$ & $\mathrm{p} 50$ & $\mathrm{p} 75$ & $\mathrm{p} 90$ & $\mathrm{p} 95$ & $\mathrm{p} 99$ & $\mathrm{max}$ \\
\hline aer (r) & 271 & 58.94 & 77.57 & 0 & 4 & 8 & 17 & 34 & 68 & 142 & 196 & 370 & 695 \\
aer (s) & 146 & 41.33 & 45.91 & 0 & 4 & 6 & 12 & 25 & 52 & 113 & 156 & 221 & 225 \\
\hline aer (all) & 417 & 52.78 & 68.63 & 0 & 4 & 7 & 14 & 31 & 62 & 128 & 177 & 342 & 695 \\
\hline ecma (r) & 85 & 65.29 & 75.65 & 0 & 6 & 7 & 25 & 44 & 70 & 143 & 176 & 510 & 510 \\
ecma (s) & 14 & 35.11 & 37.60 & 8 & 8 & 10 & 15 & 24 & 37 & 56 & 156 & 156 & 156 \\
\hline ecma (all) & 99 & 61.02 & 72.14 & 0 & 6 & 8 & 22 & 41 & 70 & 143 & 176 & 510 & 510 \\
\hline jpe & 244 & 50.66 & 64.44 & 0 & 4 & 6 & 14 & 29 & 63 & 117 & 172 & 318 & 547 \\
qje & 292 & 78.55 & 98.48 & 0 & 6 & 13 & 26 & 53 & 100 & 165 & 221 & 391 & 1,128 \\
restud & 183 & 46.34 & 117.67 & 0 & 3 & 6 & 12 & 22 & 44 & 80 & 123 & 339 & 1,468 \\
\hline All & 1,235 & 58.16 & 85.38 & 0 & 4 & 7 & 16 & 33 & 70 & 134 & 187 & 342 & 1,468 \\
\hline
\end{tabular}

Table 20 lists the top 50 articles with at least one JEL code J. See for a precise definition of the different variables Section 6.1. 
Table 20: Top 50 articles for $T=1991-2014$ Code $\mathrm{J}$, normalized per year

\begin{tabular}{|c|c|c|c|c|c|c|c|}
\hline$\widetilde{R}(\mathrm{R})$ & $\widetilde{C_{i}}\left(C_{i}\right)$ & Title & Authors & Journal & pct & Type & USA \\
\hline $1(1)$ & $1468(2143)$ & Some Tests of Specification for Panel Data & Arellano ; Bond & restud-91 & $50 \%$ & $\mathrm{D}$ & 0 \\
\hline $2(3)$ & $1128(993)$ & How Much Should We Trust Differences-in-Difference & Bertrand et al. & qje-04 & $67 \%$ & $\mathrm{D}$ & 1 \\
\hline $3(2)$ & $756(1084)$ & Changes in Relative Wages, 1963-1987 & Katz ; Murphy & qje-92 & $100 \%$ & $\mathrm{D}$ & 1 \\
\hline $4(6)$ & $695(612)$ & Are Emily and Greg More Employable than Lakisha an & Bertrand ; Mullainathan & aer-04 & $100 \%$ & $\mathrm{D}$ & 1 \\
\hline $5(4)$ & $547(734)$ & Wage Inequality and the Rise in Returns to Skill & Juhn et al. & jpe-93 & $100 \%$ & $\mathrm{D}$ & 1 \\
\hline $6(5)$ & $510(652)$ & Labor Market Institutions and the Distribution of & DiNardo et al. & ecma-96 & $100 \%$ & $\mathrm{D}$ & 0.33 \\
\hline $7(404)$ & $404(42)$ & The Growth of Low-Skill Service Jobs and the Polar & Autor ; Dorn & aer-13 & $67 \%$ & $\mathrm{~T}$ & 0.50 \\
\hline $8(17)$ & $391(393)$ & Information Technology, Workplace Organization, an & Bresnahan et al. & qje-02 & $67 \%$ & $\mathrm{D}$ & 1 \\
\hline $9(59)$ & $372(203)$ & Stature and Status & Case ; Paxson & jpe-08 & $100 \%$ & $\mathrm{D}$ & 1 \\
\hline $10(7)$ & $370(531)$ & Changes in the Structure of Wages in the 1980's & Bound ; Johnson & aer-92 & $100 \%$ & $\mathrm{~T}$ & 1 \\
\hline $11(15)$ & $367(398)$ & The Labor Demand Curve Is Downward Sloping & Borjas & qje-03 & $100 \%$ & $\mathrm{D}$ & 1 \\
\hline $12(9)$ & $355(476)$ & Earnings Losses of Displaced Workers & Jacobson et al. & aer-93 & $100 \%$ & $\mathrm{D}$ & 0.67 \\
\hline $13(13)$ & $342(415)$ & Performance Pay and Productivity & Lazear & aer-00 & $100 \%$ & $\mathrm{D}$ & 1 \\
\hline $15(10)$ & $332(455)$ & Job Creation and Job Destruction in the Theory of & Mortensen ; Pissarides & restud-94 & $67 \%$ & $\mathrm{~T}$ & 0.50 \\
\hline $16(11)$ & $330(452)$ & Minimum Wages and Employment & Card ; Krueger & aer-94 & $100 \%$ & $\mathrm{D}$ & 1 \\
\hline $17(8)$ & $324(484)$ & Matching as an Econometric Evaluation Estimator & Heckman et al. & restud-97 & $50 \%$ & $\mathrm{D}$ & 1 \\
\hline $18(14)$ & $318(407)$ & The Role of Premarket Factors in Black-White Wage & Neal ; Johnson & jpe-96 & $100 \%$ & $\mathrm{~T}$ & 1 \\
\hline $19(16)$ & $318(398)$ & High Wage Workers and High Wage Firms & Abowd et al. & ecma-99 & $100 \%$ & $\mathrm{D}$ & 0.17 \\
\hline $20(42)$ & $300(253)$ & The Cyclical Behavior of Equilibrium Unemployment & Shimer & aer-05 & $60 \%$ & $\mathrm{~T}$ & 1 \\
\hline $21(756)$ & $299(14)$ & A Grand Gender Convergence & Goldin & aer-14 & $86 \%$ & $\mathrm{~T}$ & 1 \\
\hline $22(30)$ & $294(319)$ & Networks in the Modern Economy & Munshi & qje-03 & $100 \%$ & $\mathrm{D}$ & 1 \\
\hline $23(32)$ & $289(313)$ & Performance in Competitive Environments & Gneezy et al. & qje-03 & $100 \%$ & $\mathrm{E}$ & 0.83 \\
\hline $24(35)$ & $271(286)$ & Boys Will Be Boys & Barber ; Odean & qje-01 & $50 \%$ & $\mathrm{D}$ & 1 \\
\hline $25(20)$ & $262(351)$ & Separate Spheres Bargaining and the Marriage Marke & Lundberg ; Pollak & jpe-93 & $100 \%$ & $\mathrm{~T}$ & 1 \\
\hline $26(18)$ & $260(373)$ & Optimal Incentive Contracts in the Presence of Car & Gibbons ; Murphy & jpe-92 & $100 \%$ & $\mathrm{D}$ & 1 \\
\hline $27(93)$ & $248(156)$ & Measuring Trends in Leisure & Aguiar ; Hurst & qje-07 & $100 \%$ & $\mathrm{~T}$ & 1 \\
\hline $28(22)$ & $248(340)$ & Changes in the U.S. Wage Structure 1963-1987 & Buchinsky & ecma-94 & $100 \%$ & $\mathrm{D}$ & 1 \\
\hline $29(34)$ & $248(301)$ & Economics and Identity & Akerlof ; Kranton & qje-00 & $40 \%$ & $\mathrm{~T}$ & 1 \\
\hline $32(40)$ & $242(263)$ & The Skill Content of Recent Technological Change & Autor et al. & qje-03 & $50 \%$ & $\mathrm{D}$ & 1 \\
\hline $33(224)$ & $242(77)$ & Inequality and Unemployment in a Global Economy & Helpman et al. & ecma-10 & $67 \%$ & $\mathrm{~T}$ & 0.67 \\
\hline $34(21)$ & $241(346)$ & Job Mobility and the Careers of Young Men & Topel ; Ward & qje-92 & $100 \%$ & $\mathrm{~T}$ & 0.50 \\
\hline $35(29)$ & $235(322)$ & Beauty and the Labor Market & Hamermesh ; Biddle & aer-94 & $100 \%$ & $\mathrm{D}$ & 1 \\
\hline $36(22)$ & $233(340)$ & Specific Capital, Mobility, and Wages & Topel & jpe-91 & $100 \%$ & $\mathrm{D}$ & 1 \\
\hline $37(31)$ & $230(315)$ & Estimates of the Economic Returns to Schooling fro & Ashenfelter ; Krueger & aer-94 & $100 \%$ & $\mathrm{D}$ & 1 \\
\hline $38(25)$ & $229(328)$ & Does School Quality Matter & Card ; Krueger & jpe-92 & $67 \%$ & $\mathrm{D}$ & 1 \\
\hline $39(25)$ & $225(328)$ & Social Networks and Labor-Market Outcomes & Montgomery & $\operatorname{aer}(\mathrm{s})-91$ & $100 \%$ & $\mathrm{~T}$ & 1 \\
\hline $40(71)$ & $224(189)$ & Selection on Observed and Unobserved Variables & Altonji et al. & jpe-05 & $50 \%$ & $\mathrm{D}$ & 1 \\
\hline $41(33)$ & $223(306)$ & Changes in the Demand for Skilled Labor within U.S & Berman et al. & qje-94 & $50 \%$ & $\mathrm{D}$ & 1 \\
\hline $42(37)$ & $222(274)$ & Ethnicity, Neighborhoods, and Human-Capital Extern & Borjas & aer-95 & $100 \%$ & $\mathrm{~T}$ & 1 \\
\hline $43(28)$ & $221(323)$ & Does Compulsory School Attendance Affect Schooling & Angrist ; Krueger & qje-91 & $67 \%$ & $\mathrm{D}$ & 1 \\
\hline $44(441)$ & $221(38)$ & Inequality at Work & Card et al. & $\operatorname{aer}(\mathrm{s})-12$ & $75 \%$ & $\mathrm{~T}$ & 1 \\
\hline $45(27)$ & $219(327)$ & The Effects of Human Resource Management Practices & Ichniowski et al. & aer-97 & $40 \%$ & $\mathrm{D}$ & 1 \\
\hline $46(831)$ & $218(10)$ & Measuring the Impacts of Teachers II & Chetty et al. & aer-14 & $50 \%$ & $\mathrm{D}$ & 1 \\
\hline $47(55)$ & $208(209)$ & The Power of the Pill & Goldin ; Katz & jpe-02 & $100 \%$ & $\mathrm{D}$ & 1 \\
\hline $48(197)$ & $203(86)$ & Training, Wages, and Sample Selection & Lee & restud-09 & $100 \%$ & $\mathrm{D}$ & 1 \\
\hline $49(633)$ & $202(21)$ & The Effect of Immigration along the Distribution o & Dustmann et al. & restud-13 & $100 \%$ & $\mathrm{D}$ & 0 \\
\hline $50(39)$ & $200(268)$ & Does Fairness Prevent Market Clearing & Fehr et al. & qje-93 & $67 \%$ & $\mathrm{E}$ & 0 \\
\hline
\end{tabular}




\subsection{Code E: Macroeconomics and Monetary Economics}

Table 21 reports the number of published articles with at least one JEL code E, for each journal and both the full period and our five subperiods. Publications in the AER and ECMA are decomposed in regular and shorter publications. It shows that out of 6,816 articles 1,018 have at least one JEL code E.

Table 21: $\mathrm{Nb}$ of articles with at least one JEL code E

\begin{tabular}{|c|c|c|c|c|c|c|}
\hline & All years & 91-95 & $96-00$ & 01-05 & 06-10 & $11-15$ \\
\hline $\begin{array}{l}\operatorname{aer}(\mathrm{r}) \\
\operatorname{aer}(\mathrm{s})\end{array}$ & $\begin{array}{l}311(100) \\
(30.6) \\
121(100) \\
(11.9)\end{array}$ & $\begin{array}{l}65(20.9) \\
(29.0) \\
23(19.0) \\
(10.3)\end{array}$ & $\begin{array}{l}58(18.6) \\
(34.3) \\
9(7.4) \\
(5.3)\end{array}$ & $\begin{array}{l}55(17.7) \\
(28.5) \\
25(20.7) \\
(13.0)\end{array}$ & $\begin{array}{l}54(17.4) \\
(30.2) \\
24(19.8) \\
(13.4)\end{array}$ & $\begin{array}{l}79(25.4) \\
(31.2) \\
40(33.1) \\
(15.8)\end{array}$ \\
\hline aer (all) & $\begin{array}{l}432(100) \\
(42.4) \\
\end{array}$ & $\begin{array}{l}88(20.4) \\
(39.3)\end{array}$ & $\begin{array}{l}67(15.5) \\
(39.6) \\
\end{array}$ & $\begin{array}{l}80(18.5) \\
(41.5) \\
\end{array}$ & $\begin{array}{l}78(18.1) \\
(43.6) \\
\end{array}$ & $\begin{array}{l}119(27.5) \\
(47.0)\end{array}$ \\
\hline $\begin{array}{l}\text { ecma }(r) \\
\text { ecma }(s)\end{array}$ & $\begin{array}{l}94(100) \\
(9.2) \\
8(100) \\
(0.8)\end{array}$ & $\begin{array}{l}17(18.1) \\
(7.6) \\
1(12.5) \\
(0.4)\end{array}$ & $\begin{array}{l}13(13.8) \\
(7.7) \\
2(25.0) \\
(1.2)\end{array}$ & $\begin{array}{l}17(18.1) \\
(8.8) \\
1(12.5) \\
(0.5)\end{array}$ & $\begin{array}{l}19(20.2) \\
(10.6) \\
1(12.5) \\
(0.6)\end{array}$ & $\begin{array}{l}28(29.8) \\
(11.1) \\
3(37.5) \\
(1.2) \\
\end{array}$ \\
\hline ecma (all) & $\begin{array}{l}102(100) \\
(10.0)\end{array}$ & $\begin{array}{l}18(17.6) \\
(8.0)\end{array}$ & $\begin{array}{l}15(14.7) \\
(8.9)\end{array}$ & $\begin{array}{l}18(17.6) \\
(9.3)\end{array}$ & $\begin{array}{l}20(19.6) \\
(11.2)\end{array}$ & $\begin{array}{l}31(30.4) \\
(12.3) \\
\end{array}$ \\
\hline jpe & $\begin{array}{l}162(100) \\
(15.9)\end{array}$ & $\begin{array}{l}31(19.1) \\
(13.8)\end{array}$ & $\begin{array}{l}37(22.8) \\
(21.9)\end{array}$ & $\begin{array}{l}33(20.4) \\
(17.1)\end{array}$ & $\begin{array}{l}29(17.9) \\
(16.2)\end{array}$ & $\begin{array}{l}32(19.8) \\
(12.6)\end{array}$ \\
\hline qje & $\begin{array}{l}146(100) \\
(14.3)\end{array}$ & $\begin{array}{l}43(29.5) \\
(19.2)\end{array}$ & $\begin{array}{l}29(19.9) \\
(17.2)\end{array}$ & $\begin{array}{l}23(15.8) \\
(11.9)\end{array}$ & $\begin{array}{l}22(15.1) \\
(12.3)\end{array}$ & $\begin{array}{l}29(19.9) \\
(11.5)\end{array}$ \\
\hline restud & $\begin{array}{l}176(100) \\
(17.3)\end{array}$ & $\begin{array}{l}44(25.0) \\
(19.6)\end{array}$ & $\begin{array}{l}21(11.9) \\
(12.4)\end{array}$ & $\begin{array}{l}39(22.2) \\
(20.2)\end{array}$ & $\begin{array}{l}30(17.0) \\
(16.8)\end{array}$ & $\begin{array}{l}42(23.9) \\
(16.6)\end{array}$ \\
\hline All & $\begin{array}{l}1,018(100) \\
(100)\end{array}$ & $\begin{array}{l}224(22.0) \\
(100)\end{array}$ & $\begin{array}{l}169(16.6) \\
(100)\end{array}$ & $\begin{array}{l}193(19.0) \\
(100)\end{array}$ & $\begin{array}{l}179(17.6) \\
(100)\end{array}$ & $\begin{array}{l}253(24.9) \\
(100)\end{array}$ \\
\hline
\end{tabular}

This table should be compared with Table 1. If all JEL codes were equally represented in each journal, the percentages of both tables would be the same. Macroeconomics and Monetary Economics articles are over-represented in the AER (42.4\% instead of 32.9\%), but under-represented in ECMA (10\% rather than $21 \%)$.

Table 22 summarizes the distributions of year-normalized citations for JEL code E per journal (year 2015 is excluded here). They should be compared to the ones of Table 9.

Table 22: Year-normalized citations for JEL code E

\begin{tabular}{lrrrrrrrrrrrrrr}
\hline \hline & $\mathrm{N}$ & mean & $\sigma$ & min & $\mathrm{p} 5$ & $\mathrm{p} 10$ & $\mathrm{p} 25$ & $\mathrm{p} 50$ & $\mathrm{p} 75$ & $\mathrm{p} 90$ & $\mathrm{p} 95$ & $\mathrm{p} 99$ & max \\
\hline aer (r) & 291 & 66.30 & 87.06 & 0 & 4 & 8 & 15 & 36 & 87 & 160 & 218 & 490 & 732 \\
aer (s) & 120 & 46.38 & 71.28 & 0 & 3 & 4 & 8 & 22 & 56 & 112 & 150 & 367 & 419 \\
\hline aer (all) & 411 & 60.48 & 83.18 & 0 & 3 & 6 & 13 & 32 & 72 & 149 & 213 & 419 & 732 \\
\hline ecma (r) & 91 & 55.96 & 70.32 & 1 & 4 & 10 & 15 & 25 & 66 & 170 & 250 & 330 & 330 \\
ecma (s) & 7 & 21.96 & 26.34 & 0 & 0 & 0 & 1 & 18 & 25 & 77 & 77 & 77 & 77 \\
\hline ecma (all) & 98 & 53.53 & 68.62 & 0 & 2 & 8 & 15 & 24 & 65 & 170 & 250 & 330 & 330 \\
\hline jpe & 156 & 57.15 & 118.99 & 0 & 4 & 6 & 14 & 29 & 60 & 117 & 152 & 654 & 1,243 \\
qje & 140 & 74.11 & 115.18 & 0 & 4 & 5 & 15 & 38 & 79 & 162 & 278 & 645 & 837 \\
restud & 171 & 33.25 & 57.18 & 0 & 1 & 2 & 7 & 19 & 39 & 73 & 101 & 232 & 611 \\
\hline All & 976 & 56.43 & 90.76 & 0 & 2 & 5 & 12 & 27 & 63 & 131 & 200 & 450 & 1,243 \\
\hline
\end{tabular}

Table 23 lists the top 50 articles with at least one JEL code E. See for a precise definition of the different 
variables Section 6.1.

Table 23: Top 50 articles for $T=1991-2014$ Code E, normalized per year

\begin{tabular}{|c|c|c|c|c|c|c|c|}
\hline$\widetilde{\mathrm{R}}(\mathrm{R})$ & $\widetilde{C_{i}}\left(C_{i}\right)$ & Title & Authors & Journal & pct & Type & USA \\
\hline $1(1)$ & $1243(1047)$ & Nominal Rigidities and the Dynamic Effects of a Sh & Christiano et al. & jpe-05 & $100 \%$ & $\mathrm{~T}$ & 1 \\
\hline $2(2)$ & $837(1016)$ & Monetary Policy Rules and Macroeconomic Stability & Clarida et al. & qje-00 & $100 \%$ & $\mathrm{D}$ & 0.83 \\
\hline $3(9)$ & $732(461)$ & Shocks and Frictions in US Business Cycles & Smets ; Wouters & aer-07 & $75 \%$ & $\mathrm{D}$ & 0 \\
\hline $4(3)$ & $654(978)$ & Credit Cycles & Kiyotaki ; Moore & jpe-97 & $100 \%$ & $\mathrm{~T}$ & 0.50 \\
\hline $5(5)$ & $645(809)$ & Why Do Some Countries Produce So Much More Output & Hall ; Jones & qje-99 & $50 \%$ & $\mathrm{D}$ & 1 \\
\hline $6(4)$ & $611(820)$ & Income Distribution and Macroeconomics & Galor ; Zeira & restud-93 & $100 \%$ & $\mathrm{~T}$ & 0.50 \\
\hline $7(411)$ & $523(24)$ & A Macroeconomic Model with a Financial Sector & Brunnermeier ; Sannikov & aer-14 & $57 \%$ & $\mathrm{~T}$ & 1 \\
\hline $8(6)$ & $490(702)$ & The Federal Funds Rate and the Channels of Monetar & Bernanke ; Blinder & aer-92 & $100 \%$ & $\mathrm{~T}$ & 1 \\
\hline $9(20)$ & $456(307)$ & Were There Regime Switches in U.S. Monetary Policy & Sims ; Zha & aer-06 & $100 \%$ & $\mathrm{D}$ & 1 \\
\hline $10(10)$ & $450(452)$ & An Empirical Characterization of the Dynamic Effec & Blanchard ; Perotti & qje-02 & $100 \%$ & $\mathrm{D}$ & 0.50 \\
\hline $11(7)$ & $419(509)$ & Output Fluctuations in the United States & McConnell ; Perez-Quiros & $\operatorname{aer}(\mathrm{s})-00$ & $100 \%$ & $\mathrm{~T}$ & 0.50 \\
\hline $12(36)$ & $405(221)$ & Five Facts about Prices & Nakamura ; Steinsson & qje-08 & $100 \%$ & $\mathrm{D}$ & 1 \\
\hline $13(186)$ & $394(67)$ & Debt, Deleveraging, and the Liquidity Trap & Eggertsson ; Krugman & qje-12 & $86 \%$ & $\mathrm{D}$ & 1 \\
\hline $14(63)$ & $367(156)$ & Not All Oil Price Shocks Are Alike & Kilian & $\operatorname{aer}(\mathrm{s})-09$ & $50 \%$ & $\mathrm{D}$ & 1 \\
\hline $15(13)$ & $367(387)$ & Preferences over Inflation and Unemployment & Di Tella et al. & $\operatorname{aer}(s)-01$ & $100 \%$ & $\mathrm{~T}$ & 0.33 \\
\hline $16(538)$ & $348(16)$ & Risk Shocks & Christiano et al. & aer-14 & $40 \%$ & $\mathrm{D}$ & 0.33 \\
\hline $17(8)$ & $347(507)$ & Stochastic Trends and Economic Fluctuations & King et al. & aer-91 & $100 \%$ & $\mathrm{D}$ & 0.25 \\
\hline $18(12)$ & $330(443)$ & A Simple Estimator of Cointegrating Vectors in Hig & Stock ; Watson & ecma-93 & $50 \%$ & $\mathrm{D}$ & 1 \\
\hline $19(11)$ & $306(447)$ & The Penn World Table (Mark 5) & Summers ; Heston & qje-91 & $33 \%$ & $\mathrm{D}$ & 1 \\
\hline $20(235)$ & $304(51)$ & Credit Booms Gone Bust & Schularick ; Taylor & $\operatorname{aer}(\mathrm{s})-12$ & $50 \%$ & $\mathrm{D}$ & 0.50 \\
\hline $21(80)$ & $302(128)$ & Can News about the Future Drive the Business Cycle & Jaimovich ; Rebelo & aer-09 & $100 \%$ & $\mathrm{~T}$ & 1 \\
\hline $22(21)$ & $295(297)$ & Sticky Information versus Sticky Prices & Mankiw ; Reis & qje-02 & $100 \%$ & $\mathrm{~T}$ & 1 \\
\hline $23(28)$ & $292(246)$ & A Unified Framework for Monetary Theory and Policy & Lagos ; Wright & jpe-05 & $100 \%$ & $\mathrm{D}$ & 1 \\
\hline $24(22)$ & $281(296)$ & Monetary Policy Rules Based on Real-Time Data & Orphanides & aer-01 & $100 \%$ & $\mathrm{D}$ & 1 \\
\hline $25(260)$ & $270(46)$ & What's News in Business Cycles & Schmitt-Grohe ; Uribe & ecma-12 & $83 \%$ & $\mathrm{D}$ & 1 \\
\hline $26(71)$ & $266(145)$ & The Time-Varying Volatility of Macroeconomic Fluct & Justiniano ; Primiceri & aer-08 & $100 \%$ & $\mathrm{D}$ & 1 \\
\hline $27(13)$ & $265(387)$ & Long-Run Policy Analysis and Long-Run Growth & Rebelo & jpe-91 & $50 \%$ & $\mathrm{~T}$ & 0.67 \\
\hline $28(179)$ & $264(69)$ & When Is the Government Spending Multiplier Large & Christiano et al. & jpe-11 & $50 \%$ & $\mathrm{~T}$ & 1 \\
\hline $29(18)$ & $261(322)$ & Optimal Contracts for Central Bankers & Walsh & aer-95 & $100 \%$ & $\mathrm{~T}$ & 1 \\
\hline $30(184)$ & $260(68)$ & Identifying Government Spending Shocks & Ramey & qje-11 & $50 \%$ & $\mathrm{D}$ & 1 \\
\hline $31(269)$ & $260(44)$ & Monetary Policy as Financial Stability Regulation & Stein & qje-12 & $100 \%$ & $\mathrm{~T}$ & 1 \\
\hline $32(273)$ & $258(44)$ & Macroeconomic Effects of Financial Shocks & Jermann ; Quadrini & aer-12 & $60 \%$ & $\mathrm{~T}$ & 1 \\
\hline $33(148)$ & $258(83)$ & The Macroeconomic Effects of Tax Changes & Romer ; Romer & aer-10 & $50 \%$ & $\mathrm{D}$ & 1 \\
\hline $34(33)$ & $258(227)$ & Testing for Indeterminacy & Lubik ; Schorfheide & aer-04 & $100 \%$ & $\mathrm{D}$ & 1 \\
\hline $35(15)$ & $255(381)$ & Golden Eggs and Hyperbolic Discounting & Laibson & qje-97 & $33 \%$ & $\mathrm{D}$ & 1 \\
\hline $36(16)$ & $252(362)$ & Bond Pricing and the Term Structure of Interest Ra & Heath et al. & ecma-92 & $50 \%$ & $\mathrm{~T}$ & 1 \\
\hline $37(108)$ & $252(107)$ & The Impact of Uncertainty Shocks & Bloom & ecma-09 & $43 \%$ & $\mathrm{D}$ & 0.50 \\
\hline $38(611)$ & $250(11)$ & Hazardous Times for Monetary Policy & Jimenez et al. & ecma-14 & $50 \%$ & $\mathrm{~T}$ & 0 \\
\hline $39(19)$ & $239(320)$ & Fiscal Policy in General Equilibrium & Baxter ; King & aer-93 & $100 \%$ & $\mathrm{E}$ & 1 \\
\hline $40(45)$ & $235(207)$ & Some Evidence on the Importance of Sticky Prices & Bils ; Klenow & jpe-04 & $50 \%$ & $\mathrm{D}$ & 1 \\
\hline $41(622)$ & $233(11)$ & Capital Is Back & Piketty ; Zucman & qje-14 & $71 \%$ & $\mathrm{D}$ & 0.25 \\
\hline $42(17)$ & $232(338)$ & Yield Spreads and Interest Rat & Campbell ; Shiller & restud-91 & $100 \%$ & $\mathrm{D}$ & 1 \\
\hline $43(23)$ & $226(289)$ & Inference When a Nuisance Parameter Is Not Identif & Hansen & ecma-96 & $50 \%$ & $\mathrm{D}$ & 1 \\
\hline $44(50)$ & $224(189)$ & Time Varying Structural Vector Autoregressions and & Primiceri & restud-05 & $75 \%$ & $\mathrm{D}$ & 1 \\
\hline $45(302)$ & $221(38)$ & Credit Spreads and Business Cycle Fluctuations & Gilchrist ; Zakrajsek & $\operatorname{aer}(\mathrm{s})-12$ & $50 \%$ & $\mathrm{D}$ & 1 \\
\hline $46(629)$ & $218(10)$ & Tracing Value-Added and Double Counting in Gross E & Koopman et al. & aer-14 & $40 \%$ & $\mathrm{~T}$ & 0.83 \\
\hline $47(25)$ & $213(259)$ & Habit Formation in Consumption and Its Implication & Fuhrer & aer-00 & $100 \%$ & $\mathrm{D}$ & 1 \\
\hline $48(27)$ & $203(247)$ & Financial Contagion & Allen ; Gale & jpe-00 & $50 \%$ & $\mathrm{~T}$ & 1 \\
\hline $49(59)$ & $200(168)$ & The Cyclical Behavior of Equilibrium Unemployment & Shimer & aer-05 & $40 \%$ & $\mathrm{~T}$ & 1 \\
\hline $50(31)$ & $198(240)$ & Are Recessions Good for Your Health & Ruhm & qje-00 & $50 \%$ & $\mathrm{D}$ & 1 \\
\hline
\end{tabular}




\subsection{Code G: Financial Economics}

Table 24 reports the number of published articles with at least one JEL code G, for each journal and both the full period and our five subperiods. Publications in the AER and ECMA are decomposed in regular and shorter publications. It shows that out of 6,816 articles 922 have at least one JEL code G.

Table 24: Nb of articles with at least one JEL code G

\begin{tabular}{|c|c|c|c|c|c|c|}
\hline & All years & 91-95 & 96-00 & 01-05 & $06-10$ & $11-15$ \\
\hline $\begin{array}{l}\text { aer }(\mathrm{r}) \\
\operatorname{aer}(\mathrm{s})\end{array}$ & $\begin{array}{l}244(100) \\
(26.5) \\
93(100) \\
(10.1) \\
\end{array}$ & $\begin{array}{l}34(13.9) \\
(23.0) \\
11(11.8) \\
(7.4)\end{array}$ & $\begin{array}{l}32(13.1) \\
(21.3) \\
14(15.1) \\
(9.3) \\
\end{array}$ & $\begin{array}{l}46(18.9) \\
(23.4) \\
20(21.5) \\
(10.2) \\
\end{array}$ & $\begin{array}{l}45(18.4) \\
(28.5) \\
16(17.2) \\
(10.1) \\
\end{array}$ & $\begin{array}{l}87(35.7) \\
(32.3) \\
32(34.4) \\
(11.9) \\
\end{array}$ \\
\hline aer (all) & $\begin{array}{l}337(100) \\
(36.6)\end{array}$ & $\begin{array}{l}45(13.4) \\
(30.4)\end{array}$ & $\begin{array}{l}46(13.6) \\
(30.7)\end{array}$ & $\begin{array}{l}66(19.6) \\
(33.5)\end{array}$ & $\begin{array}{l}61(18.1) \\
(38.6)\end{array}$ & $\begin{array}{l}119(35.3) \\
(44.2)\end{array}$ \\
\hline $\begin{array}{l}\text { ecma (r) } \\
\text { ecma (s) }\end{array}$ & $\begin{array}{l}115(100) \\
(12.5) \\
19(100) \\
(2.1) \\
\end{array}$ & $\begin{array}{l}13(11.3) \\
(8.8) \\
6(31.6) \\
(4.1) \\
\end{array}$ & $\begin{array}{l}14(12.2) \\
(9.3) \\
2(10.5) \\
(1.3) \\
\end{array}$ & $\begin{array}{l}24(20.9) \\
(12.2) \\
4(21.1) \\
(2.0) \\
\end{array}$ & $\begin{array}{l}20(17.4) \\
(12.7) \\
3(15.8) \\
(1.9) \\
\end{array}$ & $\begin{array}{l}44(38.3) \\
(16.4) \\
4(21.1) \\
(1.5) \\
\end{array}$ \\
\hline ecma (all) & $\begin{array}{l}134(100) \\
(14.5)\end{array}$ & $\begin{array}{l}19(14.2) \\
(12.8)\end{array}$ & $\begin{array}{l}16(11.9) \\
(10.7)\end{array}$ & $\begin{array}{l}28(20.9) \\
(14.2)\end{array}$ & $\begin{array}{l}23(17.2) \\
(14.6)\end{array}$ & $\begin{array}{l}48(35.8) \\
(17.8)\end{array}$ \\
\hline jpe & $\begin{array}{l}143(100) \\
(15.5)\end{array}$ & $\begin{array}{l}23(16.1) \\
(15.5)\end{array}$ & $\begin{array}{l}40(28.0) \\
(26.7)\end{array}$ & $\begin{array}{l}34(23.8) \\
(17.3)\end{array}$ & $\begin{array}{l}18(12.6) \\
(11.4)\end{array}$ & $\begin{array}{l}28(19.6) \\
(10.4)\end{array}$ \\
\hline qje & $\begin{array}{l}161(100) \\
(17.5)\end{array}$ & $\begin{array}{l}30(18.6) \\
(20.3)\end{array}$ & $\begin{array}{l}28(17.4) \\
(18.7)\end{array}$ & $\begin{array}{l}41(25.5) \\
(20.8)\end{array}$ & $\begin{array}{l}27(16.8) \\
(17.1)\end{array}$ & $\begin{array}{l}35(21.7) \\
(13.0)\end{array}$ \\
\hline restud & $\begin{array}{l}147(100) \\
(15.9)\end{array}$ & $\begin{array}{l}31(21.1) \\
(20.9)\end{array}$ & $\begin{array}{l}20(13.6) \\
(13.3)\end{array}$ & $\begin{array}{l}28(19.0) \\
(14.2)\end{array}$ & $\begin{array}{l}29(19.7) \\
(18.4)\end{array}$ & $\begin{array}{l}39(26.5) \\
(14.5) \\
\end{array}$ \\
\hline All & $\begin{array}{l}922(100) \\
(100)\end{array}$ & $\begin{array}{l}148(16.1) \\
(100)\end{array}$ & $\begin{array}{l}150(16.3) \\
(100)\end{array}$ & $\begin{array}{l}197(21.4) \\
(100)\end{array}$ & $\begin{array}{l}158(17.1) \\
(100)\end{array}$ & $\begin{array}{l}269(29.2) \\
(100)\end{array}$ \\
\hline
\end{tabular}

This table should be compared with Table 1. If all JEL codes were equally represented in each journals, the percentages of both tables should be the same. Financial Economics articles are slightly more present in the AER and QJE and under-represented in ECMA. Table 25 summarizes the distributions of year-normalized citations for JEL code G per journal (year 2015 is excluded here). They should be compared to the ones of Table 9 .

Table 25: Year-normalized citations for JEL code G

\begin{tabular}{lrrrrrrrrrrrrr}
\hline \hline & $\mathrm{N}$ & mean & $\sigma$ & min & $\mathrm{p} 5$ & $\mathrm{p} 10$ & $\mathrm{p} 25$ & $\mathrm{p} 50$ & $\mathrm{p} 75$ & $\mathrm{p} 90$ & $\mathrm{p} 95$ & $\mathrm{p} 99$ & $\max$ \\
\hline aer (r) & 221 & 52.86 & 62.36 & 0 & 4 & 6 & 15 & 29 & 66 & 127 & 167 & 338 & 392 \\
aer (s) & 91 & 35.18 & 45.42 & 0 & 1 & 3 & 7 & 19 & 52 & 89 & 114 & 286 & 286 \\
\hline aer (all) & 312 & 47.71 & 58.42 & 0 & 2 & 5 & 13 & 26 & 62 & 113 & 165 & 296 & 392 \\
\hline ecma (r) & 108 & 64.56 & 96.11 & 2 & 7 & 11 & 15 & 29 & 78 & 161 & 252 & 440 & 605 \\
ecma (s) & 18 & 24.47 & 31.22 & 2 & 2 & 3 & 5 & 12 & 31 & 66 & 130 & 130 & 130 \\
\hline ecma (all) & 126 & 58.83 & 90.76 & 2 & 5 & 8 & 14 & 26 & 64 & 145 & 250 & 440 & 605 \\
\hline jpe & 136 & 81.28 & 167.09 & 0 & 6 & 8 & 15 & 38 & 82 & 198 & 272 & 696 & 1,650 \\
qje & 153 & 88.10 & 120.88 & 0 & 6 & 10 & 22 & 55 & 116 & 175 & 271 & 547 & 1,077 \\
restud & 141 & 33.93 & 40.98 & 0 & 2 & 4 & 8 & 17 & 42 & 74 & 112 & 201 & 213 \\
\hline All & 868 & 59.46 & 99.84 & 0 & 3 & 6 & 13 & 29 & 68 & 142 & 202 & 417 & 1,650 \\
\hline
\end{tabular}

Table 26 lists the top 50 articles with at least one JEL code G. See for a precise definition of the different variables Section 6.1. 
Table 26: Top 50 articles for $T=1991-2014$ Code $\mathrm{G}$, normalized per year

\begin{tabular}{|c|c|c|c|c|c|c|c|}
\hline$\widetilde{R}(R)$ & $\widetilde{C_{i}}\left(C_{i}\right)$ & Title & Authors & Journal & pct & Type & USA \\
\hline $1(1)$ & $1650(2241)$ & Law and Finance & La Porta et al. & jpe-98 & $67 \%$ & $\mathrm{D}$ & 1 \\
\hline $2(2)$ & $1077(1167)$ & Corporate Governance and Equity Prices & Gompers et al. & qje-03 & $100 \%$ & $\mathrm{D}$ & 1 \\
\hline $3(3)$ & $696(872)$ & By Force of Habit & Campbell ; Cochrane & jpe-99 & $100 \%$ & $\mathrm{~T}$ & 1 \\
\hline $4(4)$ & $605(734)$ & Transform Analysis and Asset Pricing for Affine Ju & Duffie et al. & ecma-00 & $100 \%$ & $\mathrm{~T}$ & 1 \\
\hline $5(7)$ & $566(614)$ & Liquidity Risk and Expected Stock Returns & Pastor ; Stambaugh & jpe-03 & $100 \%$ & $\mathrm{D}$ & 1 \\
\hline $6(61)$ & $547(175)$ & Did Securitization Lead to Lax Screening & Keys et al. & qje-10 & $100 \%$ & $\mathrm{D}$ & 0.50 \\
\hline $7(5)$ & $455(680)$ & Do Investment-Cash Flow Sensitivities Provide Usef & Kaplan ; Zingales & qje-97 & $100 \%$ & $\mathrm{D}$ & 1 \\
\hline $8(6)$ & $440(642)$ & Conditional Heteroskedasticity in Asset Returns & Nelson & ecma-91 & $33 \%$ & $\mathrm{D}$ & 1 \\
\hline $9(9)$ & $417(514)$ & Myopic Loss Aversion and the Equity Premium Puzzle & Benartzi ; Thaler & qje-95 & $100 \%$ & $\mathrm{D}$ & 1 \\
\hline $10(8)$ & $409(597)$ & Long-Term Memory in Stock Market Prices & Lo & ecma-91 & $100 \%$ & $\mathrm{D}$ & 1 \\
\hline $11(10)$ & $400(493)$ & The Effect of Credit Market Competition on Lending & Petersen ; Rajan & qje-95 & $100 \%$ & $\mathrm{D}$ & 1 \\
\hline $12(421)$ & $392(18)$ & A Macroeconomic Model with a Financial Sector & Brunnermeier ; Sannikov & aer-14 & $43 \%$ & $\mathrm{~T}$ & 1 \\
\hline $13(15)$ & $362(393)$ & Modeling and Forecasting Realized Volatility & Andersen et al. & ecma-03 & $67 \%$ & $\mathrm{D}$ & 0.25 \\
\hline $15(17)$ & $347(366)$ & Institutional Investors and Equity Prices & Gompers ; Metrick & qje-01 & $100 \%$ & $\mathrm{D}$ & 1 \\
\hline $16(26)$ & $341(300)$ & Mutual Fund Flows and Performance in Rational Mark & Berk ; Green & jpe-04 & $100 \%$ & $\mathrm{D}$ & 1 \\
\hline $17(12)$ & $338(459)$ & Endogenously Chosen Boards of Directors and Their & Hermalin ; Weisbach & aer-98 & $100 \%$ & $\mathrm{D}$ & 1 \\
\hline $18(24)$ & $302(304)$ & Determining the Number of Factors in Approximate F & $\mathrm{Bai} ; \mathrm{Ng}$ & ecma-02 & $50 \%$ & $\mathrm{D}$ & 1 \\
\hline $19(18)$ & $296(364)$ & Momentum Investment Strategies, Portfolio Performa & Grinblatt et al. & aer-95 & $100 \%$ & $\mathrm{D}$ & 1 \\
\hline $20(20)$ & $286(358)$ & Do Investors Trade Too Much & Odean & $\operatorname{aer}(\mathrm{s})-99$ & $100 \%$ & $\mathrm{~T}$ & 1 \\
\hline $21(23)$ & $283(307)$ & Overconfidence and Speculative Bubbles & Scheinkman ; Xiong & jpe-03 & $100 \%$ & $\mathrm{~T}$ & 1 \\
\hline $22(13)$ & $280(419)$ & Risk Taking by Mutual Funds as a Response to Incen & Chevalier ; Ellison & jpe-97 & $100 \%$ & $\mathrm{D}$ & 1 \\
\hline $23(14)$ & $275(401)$ & Corporate Structure, Liquidity, and Investment & Hoshi et al. & qje-91 & $67 \%$ & $\mathrm{D}$ & 1 \\
\hline $24(28)$ & $272(287)$ & Resurrecting the $(\mathrm{C}) \mathrm{CAPM}$ & Lettau ; Ludvigson & jpe-01 & $100 \%$ & $\mathrm{D}$ & 1 \\
\hline $25(29)$ & $271(286)$ & Boys Will Be Boys & Barber ; Odean & qje-01 & $50 \%$ & $\mathrm{D}$ & 1 \\
\hline $26(22)$ & $258(330)$ & Understanding Risk and Return & Campbell & jpe-96 & $100 \%$ & $\mathrm{D}$ & 1 \\
\hline $27(16)$ & $255(381)$ & Golden Eggs and Hyperbolic Discounting & Laibson & qje-97 & $33 \%$ & $\mathrm{D}$ & 1 \\
\hline $28(19)$ & $252(362)$ & Bond Pricing and the Term Structure of Interest Ra & Heath et al. & ecma-92 & $50 \%$ & $\mathrm{~T}$ & 1 \\
\hline $29(528)$ & $250(11)$ & Hazardous Times for Monetary Policy & Jimenez et al. & ecma-14 & $50 \%$ & $\mathrm{~T}$ & 0 \\
\hline $32(33)$ & $244(265)$ & Managing with Style & Bertrand ; Schoar & qje-03 & $75 \%$ & $\mathrm{D}$ & 1 \\
\hline $33(365)$ & $231(24)$ & Intermediary Asset Pricing & He ; Krishnamurthy & aer-13 & $80 \%$ & $\mathrm{~T}$ & 1 \\
\hline $34(379)$ & $221(23)$ & Managerial Miscalibration & Ben-David et al. & q.je-13 & $100 \%$ & $\mathrm{D}$ & 1 \\
\hline $35(287)$ & $221(38)$ & Credit Spreads and Business Cycle Fluctuations & Gilchrist ; Zakrajsek & $\operatorname{aer}(\mathrm{s})-12$ & $50 \%$ & $\mathrm{D}$ & 1 \\
\hline $36(25)$ & $221(303)$ & Tobin's q, Corporate Diversification, and Firm Per & Lang ; Stulz & jpe-94 & $50 \%$ & $\mathrm{~T}$ & 0.50 \\
\hline $37(27)$ & $220(298)$ & Stock Markets, Banks, and Economic Growth & Levine ; Zervos & aer-98 & $40 \%$ & $\mathrm{D}$ & 0.50 \\
\hline $38(35)$ & $217(263)$ & Liberalization, Moral Hazard in Banking, and Prude & Hellmann et al. & aer-00 & $100 \%$ & $\mathrm{~T}$ & 0.50 \\
\hline $39(55)$ & $214(188)$ & Bad Beta, Good Beta & Campbell ; Vuolteenaho & aer-04 & $100 \%$ & $\mathrm{D}$ & 1 \\
\hline $40(105)$ & $213(116)$ & Microstructure Noise, Realized Variance, and Optim & Bandi ; Russell & restud-08 & $100 \%$ & $\mathrm{D}$ & 1 \\
\hline $41(295)$ & $212(36)$ & The Changing of the Boards & Ahern ; Dittmar & qje-12 & $60 \%$ & $\mathrm{D}$ & 1 \\
\hline $42(32)$ & $210(269)$ & Optimal Debt Structure and the Number of Creditors & Bolton ; Scharfstein & jpe-96 & $100 \%$ & $\mathrm{~T}$ & 0.50 \\
\hline $43(38)$ & $203(247)$ & Financial Contagion & Allen ; Gale & jpe-00 & $50 \%$ & $\mathrm{~T}$ & 1 \\
\hline $44(31)$ & $202(271)$ & Trading Volume and Serial Correlation in Stock Ret & Campbell et al. & q.je-93 & $100 \%$ & $\mathrm{~T}$ & 1 \\
\hline $45(86)$ & $201(135)$ & On the Nature of Capital Adjustment Costs & Cooper ; Haltiwanger & restud-06 & $100 \%$ & $\mathrm{D}$ & 1 \\
\hline $46(397)$ & $200(21)$ & Credit Constraints, Heterogeneous Firms, and Inter & Manova & restud-13 & $40 \%$ & $\mathrm{D}$ & 1 \\
\hline $47(46)$ & $198(209)$ & Liquidity Risk, Liquidity Creation, and Financial & Diamond ; Rajan & jpe-01 & $100 \%$ & $\mathrm{~T}$ & 1 \\
\hline $48(37)$ & $198(253)$ & Does Public Insurance Crowd Out Private Insurance & Cutler ; Gruber & q.je-96 & $100 \%$ & $\mathrm{D}$ & 1 \\
\hline $49(30)$ & $190(278)$ & The Role of Demandable Debt in Structuring Optimal & Calomiris ; Kahn & aer-91 & $100 \%$ & $\mathrm{~T}$ & 1 \\
\hline $50(49)$ & $189(199)$ & Dividends and Expropriation & Faccio et al. & aer-01 & $67 \%$ & $\mathrm{D}$ & 0 \\
\hline
\end{tabular}




\subsection{Code L: Industrial Organization}

Table 27 reports the number of published articles with at least one JEL code L, for each journal and both the full period and our five subperiods. Publications in the AER and ECMA are decomposed in regular and shorter publications. It shows that out of 6,816 articles 996 have at least one JEL code L.

Table 27: Nb of articles with at least one JEL code L

\begin{tabular}{|c|c|c|c|c|c|c|}
\hline & All years & $91-95$ & $96-00$ & 01-05 & 06-10 & $11-15$ \\
\hline $\begin{array}{l}\text { aer }(r) \\
\text { aer }(s)\end{array}$ & $\begin{array}{l}310(100) \\
(31.1) \\
99(100) \\
(9.9)\end{array}$ & $\begin{array}{l}35(11.3) \\
(21.9) \\
8(8.1) \\
(5.0) \\
\end{array}$ & $\begin{array}{l}39(12.6) \\
(28.3) \\
11(11.1) \\
(8.0)\end{array}$ & $\begin{array}{l}47(15.2) \\
(22.9) \\
26(26.3) \\
(12.7) \\
\end{array}$ & $\begin{array}{l}70(22.6) \\
(35.4) \\
24(24.2) \\
(12.1) \\
\end{array}$ & $\begin{array}{l}119(38.4) \\
(40.3) \\
30(30.3) \\
(10.2)\end{array}$ \\
\hline aer (all) & $\begin{array}{l}409(100) \\
(41.1)\end{array}$ & $\begin{array}{l}43(10.5) \\
(26.9)\end{array}$ & $\begin{array}{l}50(12.2) \\
(36.2)\end{array}$ & $\begin{array}{l}73(17.8) \\
(35.6)\end{array}$ & $\begin{array}{l}94(23.0) \\
(47.5)\end{array}$ & $\begin{array}{l}149(36.4) \\
(50.5)\end{array}$ \\
\hline $\begin{array}{l}\text { ecma (r) } \\
\text { ecma (s) }\end{array}$ & $\begin{array}{l}85(100) \\
(8.5) \\
7(100) \\
(0.7)\end{array}$ & $\begin{array}{l}18(21.2) \\
(11.3) \\
1(14.3) \\
(0.6) \\
\end{array}$ & $\begin{array}{l}7(8.2) \\
(5.1) \\
.(.) \\
(.)\end{array}$ & $\begin{array}{l}14(16.5) \\
(6.8) \\
3(42.9) \\
(1.5) \\
\end{array}$ & $\begin{array}{l}19(22.4) \\
(9.6) \\
1(14.3) \\
(0.5) \\
\end{array}$ & $\begin{array}{l}27(31.8) \\
(9.2) \\
2(28.6) \\
(0.7) \\
\end{array}$ \\
\hline ecma (all) & $\begin{array}{l}92(100) \\
(9.2)\end{array}$ & $\begin{array}{l}19(20.7) \\
(11.9)\end{array}$ & $\begin{array}{l}7(7.6) \\
(5.1)\end{array}$ & $\begin{array}{l}17(18.5) \\
(8.3)\end{array}$ & $\begin{array}{l}20(21.7) \\
(10.1)\end{array}$ & $\begin{array}{l}29(31.5) \\
(9.8)\end{array}$ \\
\hline jpe & $\begin{array}{l}169(100) \\
(17.0)\end{array}$ & $\begin{array}{l}32(18.9) \\
(20.0)\end{array}$ & $\begin{array}{l}35(20.7) \\
(25.4)\end{array}$ & $\begin{array}{l}46(27.2) \\
(22.4)\end{array}$ & $\begin{array}{l}25(14.8) \\
(12.6)\end{array}$ & $\begin{array}{l}31(18.3) \\
(10.5)\end{array}$ \\
\hline qje & $\begin{array}{l}175(100) \\
(17.6)\end{array}$ & $\begin{array}{l}41(23.4) \\
(25.6)\end{array}$ & $\begin{array}{l}23(13.1) \\
(16.7)\end{array}$ & $\begin{array}{l}31(17.7) \\
(15.1)\end{array}$ & $\begin{array}{l}35(20.0) \\
(17.7)\end{array}$ & $\begin{array}{l}45(25.7) \\
(15.3)\end{array}$ \\
\hline restud & $\begin{array}{l}151(100) \\
(15.2) \\
\end{array}$ & $\begin{array}{l}25(16.6) \\
(15.6)\end{array}$ & $\begin{array}{l}23(15.2) \\
(16.7) \\
\end{array}$ & $\begin{array}{l}38(25.2) \\
(18.5)\end{array}$ & $\begin{array}{l}24(15.9) \\
(12.1) \\
\end{array}$ & $\begin{array}{l}41(27.2) \\
(13.9) \\
\end{array}$ \\
\hline All & $\begin{array}{l}996(100) \\
(100)\end{array}$ & $\begin{array}{l}160(16.1) \\
(100)\end{array}$ & $\begin{array}{l}138(13.9) \\
(100)\end{array}$ & $\begin{array}{l}205(20.6) \\
(100)\end{array}$ & $\begin{array}{l}198(19.9) \\
(100)\end{array}$ & $\begin{array}{l}295(29.6) \\
(100)\end{array}$ \\
\hline
\end{tabular}

This table should be compared with Table 1. If all JEL codes were equally represented in each journal, the percentages of both tables would be the same. Industrial Organization articles are over-represented in the AER (40.4\% vs 32.9\%), slightly over-represented in JPE and QJE but drastically under-represented in ECMA (9.4\% instead of $21 \%$ ). Table 28 summarizes the distributions of year-normalized citations for JEL code L per journal (year 2015 is excluded here). They should be compared to the ones of Table 9.

Table 28: Year-normalized citations for JEL code L

\begin{tabular}{lrlrrrrrrrrrrr}
\hline \hline & $\mathrm{N}$ & mean & $\sigma$ & min & $\mathrm{p} 5$ & $\mathrm{p} 10$ & $\mathrm{p} 25$ & $\mathrm{p} 50$ & $\mathrm{p} 75$ & $\mathrm{p} 90$ & $\mathrm{p} 95$ & $\mathrm{p} 99$ & $\mathrm{max}$ \\
\hline aer (r) & 283 & 47.43 & 58.36 & 0 & 4 & 7 & 14 & 30 & 57 & 103 & 147 & 313 & 530 \\
aer (s) & 97 & 35.87 & 54.07 & 0 & 0 & 3 & 8 & 20 & 41 & 93 & 138 & 358 & 358 \\
\hline aer (all) & 380 & 44.48 & 57.45 & 0 & 3 & 6 & 13 & 27 & 54 & 102 & 139 & 313 & 530 \\
\hline ecma (r) & 82 & 63.89 & 115.06 & 2 & 6 & 7 & 12 & 31 & 71 & 121 & 185 & 743 & 743 \\
ecma (s) & 6 & 17.55 & 25.05 & 3 & 3 & 3 & 4 & 8 & 15 & 68 & 68 & 68 & 68 \\
\hline ecma (all) & 88 & 60.73 & 111.80 & 2 & 4 & 6 & 12 & 28 & 65 & 121 & 185 & 743 & 743 \\
\hline jpe & 163 & 41.66 & 49.86 & 0 & 3 & 5 & 13 & 26 & 51 & 85 & 143 & 241 & 310 \\
qje & 165 & 57.45 & 64.25 & 0 & 4 & 6 & 16 & 40 & 73 & 122 & 187 & 291 & 469 \\
restud & 145 & 35.25 & 50.24 & 0 & 2 & 4 & 7 & 17 & 46 & 81 & 128 & 200 & 427 \\
\hline All & 941 & 46.36 & 63.94 & 0 & 3 & 5 & 12 & 27 & 56 & 106 & 150 & 310 & 743 \\
\hline
\end{tabular}

Table 29 lists the top 50 articles with at least one JEL code L. See for a precise definition of the different variables Section 6.1. 
Table 29: Top 50 articles for $T=1991-2014$ Code L, normalized per year

\begin{tabular}{|c|c|c|c|c|c|c|c|}
\hline$\widetilde{\mathrm{R}}(\mathrm{R})$ & $\widetilde{C_{i}}\left(C_{i}\right)$ & Title & Authors & Journal & pct & Type & USA \\
\hline $1(1)$ & $743(915)$ & Automobile Prices in Market Equilibrium & Berry et al. & ecma-95 & $100 \%$ & $\mathrm{D}$ & 1 \\
\hline $2(2)$ & $655(710)$ & The Impact of Trade on Intra-industry Reallocation & Melitz & ecma-03 & $40 \%$ & $\mathrm{~T}$ & 1 \\
\hline $3(3)$ & $530(678)$ & Entry, Exit, Growth, and Innovation over the Produ & Klepper & aer-96 & $100 \%$ & $\mathrm{~T}$ & 1 \\
\hline $4(5)$ & $469(471)$ & The Regulation of Entry & Djankov et al. & qje-02 & $67 \%$ & $\mathrm{D}$ & 0.25 \\
\hline $5(4)$ & $427(526)$ & Markov-Perfect Industry Dynamics & Ericson ; Pakes & restud-95 & $100 \%$ & $\mathrm{D}$ & 1 \\
\hline $6(419)$ & $392(18)$ & Do Consumers Respond to Marginal or Average Price & Ito & aer-14 & $60 \%$ & $\mathrm{D}$ & 1 \\
\hline $7(8)$ & $360(380)$ & Measuring Market Power in the Ready-to-Eat Cereal & Nevo & ecma-01 & $100 \%$ & $\mathrm{D}$ & 1 \\
\hline $8(6)$ & $358(448)$ & Overconfidence and Excess Entry & Camerer ; Lovallo & $\operatorname{aer}(\mathrm{s})-99$ & $100 \%$ & $\mathrm{E}$ & 1 \\
\hline $9(83)$ & $313(100)$ & Multiple-Product Firms and Product Switching & Bernard et al. & aer-10 & $100 \%$ & $\mathrm{~T}$ & 0.67 \\
\hline $10(7)$ & $310(444)$ & Competition in the British Electricity Spot Market & Green ; Newbery & jpe-92 & $100 \%$ & $\mathrm{~T}$ & 0 \\
\hline $11(16)$ & $291(245)$ & Competition and Innovation & Aghion et al. & qje-05 & $50 \%$ & $\mathrm{D}$ & 0.40 \\
\hline $12(41)$ & $286(156)$ & Reallocation, Firm Turnover, and Efficiency & Foster et al. & aer-08 & $67 \%$ & $\mathrm{~T}$ & 1 \\
\hline $13(9)$ & $276(379)$ & Politicians and Firms & Shleifer ; Vishny & qje-94 & $67 \%$ & $\mathrm{~T}$ & 1 \\
\hline $14(10)$ & $269(366)$ & Intellectual Human Capital and the Birth of U.S. B & Zucker et al. & $\operatorname{aer}(\mathrm{s})-98$ & $50 \%$ & $\mathrm{D}$ & 1 \\
\hline $15(35)$ & $267(168)$ & Measuring and Explaining Management Practices acro & Bloom ; Van Reenen & qje-07 & $50 \%$ & $\mathrm{D}$ & 0.25 \\
\hline $16(48)$ & $241(132)$ & Trading Tasks & Grossman ; Rossi-Hansberg & aer-08 & $50 \%$ & $\mathrm{~T}$ & 1 \\
\hline $17(39)$ & $241(162)$ & Media Bias and Reputation & Gentzkow ; Shapiro & jpe-06 & $100 \%$ & $\mathrm{D}$ & 1 \\
\hline $18(27)$ & $235(207)$ & Some Evidence on the Importance of Sticky Prices & Bils ; Klenow & jpe-04 & $50 \%$ & $\mathrm{D}$ & 1 \\
\hline $19(21)$ & $233(234)$ & Measuring Market Inefficiencies in California's Re & Borenstein et al. & aer-02 & $100 \%$ & $\mathrm{D}$ & 1 \\
\hline $20(12)$ & $223(306)$ & Changes in the Demand for Skilled Labor within U.S & Berman et al. & qje-94 & $50 \%$ & $\mathrm{D}$ & 1 \\
\hline $21(13)$ & $221(303)$ & Tobin's q, Corporate Diversification, and Firm Per & Lang ; Stulz & jpe-94 & $50 \%$ & $\mathrm{~T}$ & 0.50 \\
\hline $22(11)$ & $219(327)$ & The Effects of Human Resource Management Practices & Ichniowski et al. & aer-97 & $40 \%$ & $\mathrm{D}$ & 1 \\
\hline $23(265)$ & $218(37)$ & Testing for Altruism and Social Pressure in Charit & DellaVigna et al. & q.je-12 & $50 \%$ & $\mathrm{D}$ & 1 \\
\hline $24(14)$ & $216(296)$ & Monetary Policy, Business Cycles, and the Behavior & Gertler ; Gilchrist & qje-94 & $67 \%$ & $\mathrm{~T}$ & 1 \\
\hline $25(31)$ & $207(174)$ & A Measure of Media Bias & Groseclose ; Milyo & qje-05 & $100 \%$ & $\mathrm{D}$ & 1 \\
\hline $26(394)$ & $200(21)$ & Credit Constraints, Heterogeneous Firms, and Inter & Manova & restud-13 & $40 \%$ & $\mathrm{D}$ & 1 \\
\hline $27(24)$ & $198(215)$ & On the Evolution of the Firm Size Distribution & Cabral ; Mata & aer-03 & $100 \%$ & $\mathrm{D}$ & 0.50 \\
\hline $28(15)$ & $195(291)$ & Geographic Concentration in U.S. Manufacturing Ind & Ellison ; Glaeser & jpe-97 & $50 \%$ & $\mathrm{D}$ & 1 \\
\hline $29(49)$ & $193(130)$ & Politically Connected Firms & Faccio & $\operatorname{aer}(\mathrm{s})-06$ & $33 \%$ & $\mathrm{~T}$ & 1 \\
\hline $30(17)$ & $190(244)$ & Competition and Corporate Performance & Nickell & jpe-96 & $50 \%$ & $\mathrm{D}$ & 0 \\
\hline $31(19)$ & $188(241)$ & The Dynamics of Productivity in the Telecommunicat & Olley ; Pakes & ecma-96 & $50 \%$ & $\mathrm{D}$ & 1 \\
\hline $32(30)$ & $187(188)$ & Integration versus Outsourcing in Industry Equilib & Grossman ; Helpman & qje-02 & $75 \%$ & $\mathrm{~T}$ & 0.75 \\
\hline $33(107)$ & $185(78)$ & Market Structure and Multiple Equilibria in Airlin & Ciliberto ; Tamer & ecma-09 & $80 \%$ & $\mathrm{E}$ & 1 \\
\hline $34(412)$ & $180(19)$ & Are Consumers Myopic & Busse et al. & aer-13 & $67 \%$ & $\mathrm{D}$ & 1 \\
\hline $35(18)$ & $179(243)$ & Financial Dependence and Growth & Rajan ; Zingales & aer-98 & $20 \%$ & $\mathrm{D}$ & 1 \\
\hline $36(416)$ & $176(18)$ & Does Management Matter & Bloom et al. & qje-13 & $33 \%$ & $\mathrm{D}$ & 0.90 \\
\hline $37(612)$ & $174(8)$ & Risk Shocks & Christiano et al. & aer-14 & $20 \%$ & $\mathrm{D}$ & 0.33 \\
\hline $38(20)$ & $174(238)$ & The Life Cycle of a Competitive Industry & Jovanovic ; MacDonald & jpe-94 & $100 \%$ & $\mathrm{D}$ & 1 \\
\hline $39(25)$ & $169(212)$ & Measuring Duopoly Power in the British Electricity & Wolfram & aer-99 & $100 \%$ & $\mathrm{D}$ & 1 \\
\hline $40(69)$ & $165(104)$ & Selection, Growth, and the Size Distribution of Fi & Luttmer & qje-07 & $100 \%$ & $\mathrm{D}$ & 1 \\
\hline $41(75)$ & $163(103)$ & Inside the Family Firm & Bennedsen et al. & qje-07 & $50 \%$ & $\mathrm{D}$ & 0.50 \\
\hline $42(77)$ & $161(101)$ & Vertical Relationships between Manufacturers and R & Villas-Boas & restud-07 & $100 \%$ & $\mathrm{D}$ & 1 \\
\hline $43(338)$ & $159(27)$ & Prices, Plant Size, and Product Quality & Kugler ; Verhoogen & restud-12 & $50 \%$ & $\mathrm{D}$ & 1 \\
\hline $44(199)$ & $159(51)$ & What Causes Industry Agglomeration & Ellison et al. & aer-10 & $40 \%$ & $\mathrm{D}$ & 1 \\
\hline $45(29)$ & $154(190)$ & Competition When Consumers Have Switching Costs & Klemperer & restud-95 & $50 \%$ & $\mathrm{~T}$ & 0 \\
\hline $46(37)$ & $152(165)$ & Estimating Production Functions Using Inputs to Co & Levinsohn ; Petrin & restud-03 & $25 \%$ & $\mathrm{D}$ & 1 \\
\hline $47(86)$ & $152(95)$ & Internet Advertising and the Generalized Second-Pr & Edelman et al. & aer-07 & $33 \%$ & $\mathrm{~T}$ & 0.67 \\
\hline $48(248)$ & $150(39)$ & An Anatomy of International Trade & Eaton et al. & ecma-11 & $33 \%$ & $\mathrm{D}$ & 0.67 \\
\hline $49(23)$ & $148(216)$ & Entry and Competition in Concentrated Markets & Bresnahan ; Reiss & jpe-91 & $67 \%$ & $\mathrm{D}$ & 1 \\
\hline $50(22)$ & $147(221)$ & The Decision to Export in Colombia & Roberts ; Tybout & aer-97 & $50 \%$ & $\mathrm{D}$ & 1 \\
\hline
\end{tabular}




\subsection{Code O: Economic Development, Innovation, Technological Change, and Growth}

Table 30 reports the number of published articles with at least one JEL code O, for each journal and both the full period and our five subperiods. Publications in the AER and ECMA are decomposed in regular and shorter publications. It shows that out of 6,816 articles 859 have at least one JEL code O.

Table 30: Nb of articles with at least one JEL code O

\begin{tabular}{|c|c|c|c|c|c|c|}
\hline & All years & $91-95$ & $96-00$ & 01-05 & 06-10 & $11-15$ \\
\hline $\begin{array}{l}\text { aer }(\mathrm{r}) \\
\operatorname{aer}(\mathrm{s})\end{array}$ & $\begin{array}{l}275(100) \\
(32.0) \\
70(100) \\
(8.1) \\
\end{array}$ & $\begin{array}{l}30(10.9) \\
(23.4) \\
6(8.6) \\
(4.7) \\
\end{array}$ & $\begin{array}{l}48(17.5) \\
(30.4) \\
7(10.0) \\
(4.4) \\
\end{array}$ & $\begin{array}{l}54(19.6) \\
(32.5) \\
15(21.4) \\
(9.0)\end{array}$ & $\begin{array}{l}52(18.9) \\
(29.7) \\
22(31.4) \\
(12.6) \\
\end{array}$ & $\begin{array}{l}91(33.1) \\
(39.2) \\
20(28.6) \\
(8.6)\end{array}$ \\
\hline aer (all) & $\begin{array}{l}345(100) \\
(40.2)\end{array}$ & $\begin{array}{l}36(10.4) \\
(28.1)\end{array}$ & $\begin{array}{l}55(15.9) \\
(34.8)\end{array}$ & $\begin{array}{l}69(20.0) \\
(41.6)\end{array}$ & $\begin{array}{l}74(21.4) \\
(42.3)\end{array}$ & $\begin{array}{l}111(32.2) \\
(47.8)\end{array}$ \\
\hline $\begin{array}{l}\text { ecma (r) } \\
\text { ecma (s) }\end{array}$ & $\begin{array}{l}52(100) \\
(6.1) \\
7(100) \\
(0.8) \\
\end{array}$ & $\begin{array}{l}8(15.4) \\
(6.3) \\
.(.) \\
(.) \\
\end{array}$ & $\begin{array}{l}8(15.4) \\
(5.1) \\
2(28.6) \\
(1.3) \\
\end{array}$ & $\begin{array}{l}5(9.6) \\
(3.0) \\
2(28.6) \\
(1.2) \\
\end{array}$ & $\begin{array}{l}8(15.4) \\
(4.6) \\
1(14.3) \\
(0.6) \\
\end{array}$ & $\begin{array}{l}23(44.2) \\
(9.9) \\
2(28.6) \\
(0.9) \\
\end{array}$ \\
\hline ecma (all) & $\begin{array}{l}59(100) \\
(6.9)\end{array}$ & $\begin{array}{l}8(13.6) \\
(6.3)\end{array}$ & $\begin{array}{l}10(16.9) \\
(6.3)\end{array}$ & $\begin{array}{l}7(11.9) \\
(4.2)\end{array}$ & $\begin{array}{l}9(15.3) \\
(5.1)\end{array}$ & $\begin{array}{l}25(42.4) \\
(10.8)\end{array}$ \\
\hline jpe & $\begin{array}{l}132(100) \\
(15.4)\end{array}$ & $\begin{array}{l}32(24.2) \\
(25.0)\end{array}$ & $\begin{array}{l}30(22.7) \\
(19.0)\end{array}$ & $\begin{array}{l}22(16.7) \\
(13.3)\end{array}$ & $\begin{array}{l}26(19.7) \\
(14.9)\end{array}$ & $\begin{array}{l}22(16.7) \\
(9.5)\end{array}$ \\
\hline qje & $\begin{array}{l}207(100) \\
(24.1)\end{array}$ & $\begin{array}{l}37(17.9) \\
(28.9)\end{array}$ & $\begin{array}{l}42(20.3) \\
(26.6)\end{array}$ & $\begin{array}{l}38(18.4) \\
(22.9)\end{array}$ & $\begin{array}{l}42(20.3) \\
(24.0)\end{array}$ & $\begin{array}{l}48(23.2) \\
(20.7)\end{array}$ \\
\hline restud & $\begin{array}{l}116(100) \\
(13.5)\end{array}$ & $\begin{array}{l}15(12.9) \\
(11.7)\end{array}$ & $\begin{array}{l}21(18.1) \\
(13.3)\end{array}$ & $\begin{array}{l}30(25.9) \\
(18.1)\end{array}$ & $\begin{array}{l}24(20.7) \\
(13.7)\end{array}$ & $\begin{array}{l}26(22.4) \\
(11.2)\end{array}$ \\
\hline All & $\begin{array}{l}859(100) \\
(100)\end{array}$ & $\begin{array}{l}128(14.9) \\
(100)\end{array}$ & $\begin{array}{l}158(18.4) \\
(100)\end{array}$ & $\begin{array}{l}166(19.3) \\
(100)\end{array}$ & $\begin{array}{l}175(20.4) \\
(100)\end{array}$ & $\begin{array}{l}232(27.0) \\
(100)\end{array}$ \\
\hline
\end{tabular}

This table should be compared with Table 1. If all JEL codes were equally represented in each journal, the percentages of both tables would be the same. Code $\mathrm{O}$ articles are relatively more present in the AER (39.5 vs $32.9 \%$ ) and QJE (24.3 vs $15.4 \%$ ) but less in ECMA (6.6 vs $21 \%$ ). Table 31 summarizes the distributions of year-normalized citations for JEL code O per journal (year 2015 is excluded here). They should be compared to the ones of Table 9 .

Table 31: Year-normalized citations for JEL code O

\begin{tabular}{lrcrrrrrrrrrrr}
\hline \hline & $\mathrm{N}$ & mean & $\sigma$ & min & $\mathrm{p} 5$ & $\mathrm{p} 10$ & $\mathrm{p} 25$ & $\mathrm{p} 50$ & $\mathrm{p} 75$ & $\mathrm{p} 90$ & $\mathrm{p} 95$ & $\mathrm{p} 99$ & max \\
\hline aer (r) & 252 & 74.16 & 111.55 & 0 & 6 & 8 & 19 & 39 & 81 & 176 & 265 & 663 & 1,070 \\
aer (s) & 70 & 52.08 & 81.03 & 0 & 3 & 5 & 12 & 27 & 58 & 103 & 193 & 512 & 512 \\
\hline aer (all) & 322 & 69.36 & 105.95 & 0 & 5 & 8 & 16 & 35 & 75 & 175 & 264 & 512 & 1,070 \\
\hline ecma (r) & 48 & 84.35 & 156.52 & 2 & 7 & 9 & 14 & 36 & 99 & 181 & 210 & 1,055 & 1,055 \\
ecma (s) & 6 & 41.88 & 23.13 & 13 & 13 & 13 & 26 & 40 & 53 & 80 & 80 & 80 & 80 \\
\hline ecma (all) & 54 & 79.64 & 148.18 & 2 & 7 & 10 & 15 & 37 & 80 & 178 & 210 & 1,055 & 1,055 \\
\hline jpe & 128 & 54.93 & 80.42 & 0 & 2 & 4 & 11 & 31 & 60 & 139 & 184 & 426 & 591 \\
qje & 198 & 108.18 & 207.63 & 1 & 7 & 12 & 24 & 51 & 104 & 216 & 444 & 1,447 & 1,609 \\
restud & 113 & 42.19 & 51.12 & 1 & 4 & 6 & 10 & 22 & 56 & 110 & 146 & 250 & 268 \\
\hline All & 815 & 73.44 & 134.72 & 0 & 4 & 7 & 15 & 36 & 78 & 164 & 258 & 645 & 1,609 \\
\hline
\end{tabular}

Table 32 lists the top 50 articles with at least one JEL code O. See for a precise definition of the different variables Section 6.1. 
Table 32: Top 50 articles for $T=1991-2014$ Code O, normalized per year

\begin{tabular}{|c|c|c|c|c|c|c|c|}
\hline$\widetilde{R}(R)$ & $\widetilde{C_{i}}\left(C_{i}\right)$ & Title & Authors & Journal & pct & Type & USA \\
\hline $1(1)$ & $1609(2349)$ & Economic Growth in a Cross Section of Countries & Barro & qje-91 & $100 \%$ & $\mathrm{D}$ & 1 \\
\hline $2(2)$ & $1447(2075)$ & A Contribution to the Empirics of Economic Growth & Mankiw et al. & qje-92 & $100 \%$ & $\mathrm{D}$ & 1 \\
\hline $3(3)$ & $1429(1917)$ & Geographic Localization of Knowledge Spillovers as & Jaffe et al. & q.je-93 & $100 \%$ & $\mathrm{D}$ & 0.67 \\
\hline $4(4)$ & $1070(1534)$ & A Sensitivity Analysis of Cross-Country Growth Reg & Levine ; Renelt & aer-92 & $100 \%$ & $\mathrm{D}$ & 1 \\
\hline $5(5)$ & $1055(1512)$ & A Model of Growth through Creative Destruction & Aghion ; Howitt & ecma-92 & $100 \%$ & $\mathrm{~T}$ & 0 \\
\hline $6(6)$ & $767(1029)$ & Finance and Growth & King ; Levine & qje-93 & $100 \%$ & $\mathrm{D}$ & 1 \\
\hline $7(10)$ & $736(776)$ & The Colonial Origins of Comparative Development & Acemoglu et al. & aer-01 & $40 \%$ & $\mathrm{D}$ & 1 \\
\hline $8(7)$ & $663(909)$ & Productivity Growth, Technical Progress, and Effic & Fare et al. & aer-94 & $100 \%$ & $\mathrm{D}$ & 0.25 \\
\hline $9(9)$ & $645(809)$ & Why Do Some Countries Produce So Much More Output & Hall ; Jones & qje-99 & $50 \%$ & $\mathrm{D}$ & 1 \\
\hline $10(8)$ & $612(893)$ & The Penn World Table (Mark 5) & Summers ; Heston & q.je-91 & $67 \%$ & $\mathrm{D}$ & 1 \\
\hline $11(12)$ & $591(728)$ & R\&D-based models of economic growth & Jones & jpe-95 & $100 \%$ & $\mathrm{~T}$ & 1 \\
\hline $12(14)$ & $533(657)$ & Growth Empirics & Islam & qje- 95 & $100 \%$ & $\mathrm{D}$ & 1 \\
\hline $13(15)$ & $512(655)$ & R\&D spillovers and the geography of innovation an & Audretsch ; Feldman & $\operatorname{aer}(\mathrm{s})-96$ & $50 \%$ & $\mathrm{D}$ & 0.50 \\
\hline $14(11)$ & $491(734)$ & Africa's Growth Tragedy & Easterly ; Levine & qje-97 & $67 \%$ & $\mathrm{D}$ & 1 \\
\hline $15(17)$ & $464(571)$ & The Tyranny of Numbers & Young & qje-95 & $100 \%$ & $\mathrm{D}$ & 1 \\
\hline $16(13)$ & $444(664)$ & Does Social Capital Have an Economic Payoff & Knack ; Keefer & qje-97 & $50 \%$ & $\mathrm{D}$ & 1 \\
\hline $17(16)$ & $426(611)$ & Growth in Cities & Glaeser et al. & jpe-92 & $50 \%$ & $\mathrm{D}$ & 0.25 \\
\hline $18(18)$ & $415(512)$ & Economic Growth and the Enviror & Grossman ; Krueger & q.je-95 & $50 \%$ & $\mathrm{D}$ & 1 \\
\hline $19(19)$ & $395(479)$ & Aid, Policies, and Growth & Burnside ; Dollar & aer-00 & $67 \%$ & $\mathrm{D}$ & 1 \\
\hline $20(20)$ & $378(474)$ & Does Trade Cause Growth & Frankel ; Romer & aer-99 & $50 \%$ & $\mathrm{D}$ & 1 \\
\hline $21(23)$ & $328(404)$ & Time Series Tests of Endogenous Growth Models & Jones & qje-95 & $100 \%$ & $\mathrm{D}$ & 1 \\
\hline $22(30)$ & $322(340)$ & Proofs and Prototypes for Sale & Jensen ; Thursby & aer-01 & $100 \%$ & $\mathrm{D}$ & 1 \\
\hline $23(33)$ & $321(323)$ & R\&D Cooperation and Spillovers & Cassiman ; Veugelers & $\operatorname{aer}(\mathrm{s})-02$ & $100 \%$ & $\mathrm{D}$ & 0 \\
\hline $24(21)$ & $310(445)$ & Research Joint Ventures and R & Kamien et al. & aer-92 & $100 \%$ & $\mathrm{~T}$ & 0.33 \\
\hline $25(176)$ & $308(80)$ & Trade Liberalization, Exports, and Technology Upgr & Bustos & aer-11 & $60 \%$ & $\mathrm{D}$ & 0 \\
\hline $26(22)$ & $298(409)$ & Distributive Politics and Economic Growth & Alesina ; Rodrik & qje-94 & $50 \%$ & $\mathrm{D}$ & 1 \\
\hline $27(37)$ & $296(297)$ & Reversal of Fortune & Acemoglu et al. & qje-02 & $40 \%$ & $\mathrm{D}$ & 1 \\
\hline $28(26)$ & $295(369)$ & Do Domestic Firms Benefit from Direct Foreign Inve & Aitken ; Harrison & aer-99 & $50 \%$ & $\mathrm{D}$ & 1 \\
\hline $29(53)$ & $291(245)$ & Competition and Innovation & Aghion et al. & qje-05 & $50 \%$ & $\mathrm{D}$ & 0.40 \\
\hline $30(51)$ & $283(249)$ & Economic Shocks and Civil Conflict & Miguel et al. & jpe-04 & $60 \%$ & $\mathrm{D}$ & 1 \\
\hline $31(25)$ & $271(372)$ & Is Inequality Harmful for Growth & Persson ; Tabellini & aer-94 & $50 \%$ & $\mathrm{D}$ & 0 \\
\hline $32(32)$ & $271(329)$ & Population, Technology, and Growth & Galor ; Weil & aer-00 & $67 \%$ & $\mathrm{~T}$ & 0.75 \\
\hline $33(27)$ & $269(366)$ & Intellectual Human Capital and the Birth of U.S. B & Zucker et al. & $\operatorname{aer}(\mathrm{s})-98$ & $50 \%$ & $\mathrm{D}$ & 1 \\
\hline $34(45)$ & $268(269)$ & Directed Technical Change & Acemoglu & restud-02 & $100 \%$ & $\mathrm{~T}$ & 1 \\
\hline $35(168)$ & $267(86)$ & Learning about a New Technology & Conley ; Udry & aer-10 & $50 \%$ & $\mathrm{D}$ & 1 \\
\hline $36(123)$ & $266(112)$ & Misallocation and Manufacturing TFP in China and I & Hsieh ; Klenow & qje-09 & $40 \%$ & $\mathrm{D}$ & 1 \\
\hline $37(96)$ & $265(145)$ & Trade, Quality Upgrading, and Wage Inequality in t & Verhoogen & qje-08 & $67 \%$ & $\mathrm{D}$ & 1 \\
\hline $38(24)$ & $265(387)$ & Long-Run Policy Analysis and Long-Run Growth & Rebelo & jpe-91 & $50 \%$ & $\mathrm{~T}$ & 0.67 \\
\hline $39(46)$ & $265(266)$ & Geographic Localization of International Technolog & Keller & aer-02 & $100 \%$ & $\mathrm{D}$ & 1 \\
\hline $40(35)$ & $264(320)$ & A Reassessment of the Relationship between Inequal & Forbes & aer-00 & $100 \%$ & $\mathrm{D}$ & 1 \\
\hline $41(34)$ & $258(323)$ & The Twin Crises & Kaminsky ; Reinhart & aer-99 & $40 \%$ & $\mathrm{D}$ & 1 \\
\hline $42(48)$ & $258(259)$ & Fear of Floating & Calvo ; Reinhart & qje-02 & $50 \%$ & $\mathrm{~T}$ & 0.75 \\
\hline $43(28)$ & $250(365)$ & Financial Intermediation and Endogenous Growth & Bencivenga ; Smith & restud-91 & $100 \%$ & $\mathrm{~T}$ & 1 \\
\hline $44(29)$ & $243(364)$ & Long-Run Implications of Investment-Specific Techn & Greenwood et al. & aer-97 & $100 \%$ & $\mathrm{D}$ & 0.50 \\
\hline $45(31)$ & $232(333)$ & Convergence & Barro ; Sala-i-Martin & jpe-92 & $25 \%$ & $\mathrm{D}$ & 1 \\
\hline $46(36)$ & $220(298)$ & Stock Markets, Banks, and Economic Growth & Levine ; Zervos & aer-98 & $40 \%$ & $\mathrm{D}$ & 0.50 \\
\hline $47(72)$ & $219(193)$ & Does Foreign Direct Investment Increase the Produc & Javorcik & aer-04 & $40 \%$ & $\mathrm{D}$ & 1 \\
\hline $48(60)$ & $219(220)$ & Natural Selection and the Origin of Economic Growt & Galor ; Moav & qje-02 & $100 \%$ & $\mathrm{~T}$ & 0.25 \\
\hline $49(39)$ & $216(296)$ & The Management of Innovation & Aghion ; Tirole & qje-94 & $100 \%$ & $\mathrm{~T}$ & 0.25 \\
\hline $50(405)$ & $215(22)$ & The "Out of Africa" Hypothesis, Human Genetic Dive & Ashraf ; Galor & aer-13 & $33 \%$ & $\mathrm{D}$ & 1 \\
\hline
\end{tabular}




\subsection{Code F: International Economics}

Table 33 reports the number of published articles with at least one JEL code F, for each journal and both the full period and our five subperiods. Publications in the AER and ECMA are decomposed in regular and shorter publications. It shows that out of 6,816 articles 543 have at least one JEL code F.

Table 33: $\mathrm{Nb}$ of articles with at least one JEL code F

\begin{tabular}{|c|c|c|c|c|c|c|}
\hline & All years & $91-95$ & 96-00 & 01-05 & $06-10$ & $11-15$ \\
\hline $\begin{array}{l}\text { aer }(\mathrm{r}) \\
\operatorname{aer}(\mathrm{s})\end{array}$ & $\begin{array}{l}191(100) \\
(35.2) \\
57(100) \\
(10.5) \\
\end{array}$ & $\begin{array}{l}35(18.3) \\
(34.0) \\
11(19.3) \\
(10.7) \\
\end{array}$ & $\begin{array}{l}41(21.5) \\
(51.9) \\
7(12.3) \\
(8.9) \\
\end{array}$ & $\begin{array}{l}39(20.4) \\
(33.1) \\
13(22.8) \\
(11.0) \\
\end{array}$ & $\begin{array}{l}30(15.7) \\
(27.5) \\
15(26.3) \\
(13.8) \\
\end{array}$ & $\begin{array}{l}46(24.1) \\
(34.3) \\
11(19.3) \\
(8.2) \\
\end{array}$ \\
\hline aer (all) & $\begin{array}{l}248(100) \\
(45.7)\end{array}$ & $\begin{array}{l}46(18.5) \\
(44.7)\end{array}$ & $\begin{array}{l}48(19.4) \\
(60.8)\end{array}$ & $\begin{array}{l}52(21.0) \\
(44.1)\end{array}$ & $\begin{array}{l}45(18.1) \\
(41.3)\end{array}$ & $\begin{array}{l}57(23.0) \\
(42.5) \\
\end{array}$ \\
\hline $\begin{array}{l}\text { ecma (r) } \\
\text { ecma (s) }\end{array}$ & $\begin{array}{l}23(100) \\
(4.2) \\
5(100) \\
(0.9) \\
\end{array}$ & $\begin{array}{l}5(21.7) \\
(4.9) \\
2(40.0) \\
(1.9) \\
\end{array}$ & $\begin{array}{l}.(.) \\
(.) \\
.(.) \\
(.) \\
\end{array}$ & $\begin{array}{l}6(26.1) \\
(5.1) \\
.(.) \\
(.) \\
\end{array}$ & $\begin{array}{l}5(21.7) \\
(4.6) \\
1(20.0) \\
(0.9) \\
\end{array}$ & $\begin{array}{l}7(30.4) \\
(5.2) \\
2(40.0) \\
(1.5) \\
\end{array}$ \\
\hline ecma (all) & $\begin{array}{l}28(100) \\
(5.2)\end{array}$ & $\begin{array}{l}7(25.0) \\
(6.8)\end{array}$ & $\begin{array}{l}.(.) \\
(.) \\
\end{array}$ & $\begin{array}{l}6(21.4) \\
(5.1)\end{array}$ & $\begin{array}{l}6(21.4) \\
(5.5)\end{array}$ & $\begin{array}{l}9(32.1) \\
(6.7)\end{array}$ \\
\hline jpe & $\begin{array}{l}72(100) \\
(13.3)\end{array}$ & $\begin{array}{l}12(16.7) \\
(11.7)\end{array}$ & $\begin{array}{l}14(19.4) \\
(17.7)\end{array}$ & $\begin{array}{l}20(27.8) \\
(16.9)\end{array}$ & $\begin{array}{l}11(15.3) \\
(10.1)\end{array}$ & $\begin{array}{l}15(20.8) \\
(11.2)\end{array}$ \\
\hline & $\begin{array}{l}105(100) \\
(19.3)\end{array}$ & $\begin{array}{l}22(21.0) \\
(21.4)\end{array}$ & $\begin{array}{l}10(9.5) \\
(12.7)\end{array}$ & $\begin{array}{l}23(21.9) \\
(19.5)\end{array}$ & $\begin{array}{l}23(21.9) \\
(21.1)\end{array}$ & $\begin{array}{l}27(25.7) \\
(20.1)\end{array}$ \\
\hline restud & $\begin{array}{l}90(100) \\
(16.6)\end{array}$ & $\begin{array}{l}16(17.8) \\
(15.5)\end{array}$ & $\begin{array}{l}7(7.8) \\
(8.9) \\
\end{array}$ & $\begin{array}{l}17(18.9) \\
(14.4)\end{array}$ & $\begin{array}{l}24(26.7) \\
(22.0)\end{array}$ & $\begin{array}{l}26(28.9) \\
(19.4) \\
\end{array}$ \\
\hline All & $\begin{array}{l}543(100) \\
(100)\end{array}$ & $\begin{array}{l}103(19.0) \\
(100)\end{array}$ & $\begin{array}{l}79(14.5) \\
(100)\end{array}$ & $\begin{array}{l}118(21.7) \\
(100)\end{array}$ & $\begin{array}{l}109(20.1) \\
(100)\end{array}$ & $\begin{array}{l}134(24.7) \\
(100)\end{array}$ \\
\hline
\end{tabular}

This table should be compared with Table 1. If all JEL codes were equally represented in each journal, the percentages of both tables would be the same. International Economics articles are relatively more present in the AER (45.9 vs $32.9 \%$ ) and QJE (19.1 vs $15.4 \%$ ) but less in ECMA (5.4 vs 21\%). Table 34 summarizes the distributions of year-normalized citations for JEL code F per journal (year 2015 is excluded here). They should be compared to the ones of Table 9 .

Table 34: Year-normalized citations for JEL code F

\begin{tabular}{lrccrrrrrrrrrr}
\hline \hline & $\mathrm{N}$ & mean & $\sigma$ & min & $\mathrm{p} 5$ & $\mathrm{p} 10$ & $\mathrm{p} 25$ & $\mathrm{p} 50$ & $\mathrm{p} 75$ & $\mathrm{p} 90$ & $\mathrm{p} 95$ & $\mathrm{p} 99$ & $\mathrm{max}$ \\
\hline aer (r) & 183 & 76.38 & 106.08 & 0 & 7 & 10 & 22 & 45 & 86 & 182 & 239 & 549 & 972 \\
aer (s) & 57 & 62.34 & 134.80 & 1 & 2 & 7 & 13 & 19 & 39 & 125 & 382 & 833 & 833 \\
\hline aer (all) & 240 & 73.05 & 113.41 & 0 & 7 & 9 & 16 & 39 & 79 & 174 & 270 & 549 & 972 \\
\hline ecma (r) & 23 & 113.68 & 204.93 & 7 & 15 & 19 & 39 & 56 & 70 & 226 & 369 & 982 & 982 \\
ecma (s) & 5 & 13.78 & 8.51 & 4 & 4 & 4 & 7 & 13 & 19 & 25 & 25 & 25 & 25 \\
\hline ecma (all) & 28 & 95.84 & 189.07 & 4 & 7 & 7 & 20 & 47 & 66 & 226 & 369 & 982 & 982 \\
\hline jpe & 71 & 67.78 & 74.47 & 0 & 2 & 7 & 14 & 33 & 103 & 164 & 198 & 383 & 383 \\
qje & 100 & 85.23 & 112.71 & 0 & 5 & 8 & 23 & 50 & 108 & 194 & 229 & 658 & 810 \\
restud & 84 & 53.79 & 87.10 & 0 & 5 & 6 & 10 & 26 & 61 & 118 & 188 & 651 & 651 \\
\hline All & 523 & 72.79 & 110.53 & 0 & 5 & 8 & 16 & 39 & 83 & 168 & 230 & 549 & 982 \\
\hline
\end{tabular}

Table 35 lists the top 50 articles with at least one JEL code F. See for a precise definition of the different variables Section 6.1. 
Table 35: Top 50 articles for $T=1991-2014$ Code F, normalized per year

\begin{tabular}{|c|c|c|c|c|c|c|c|}
\hline$\widetilde{R}(R)$ & $\widetilde{C_{i}}\left(C_{i}\right)$ & Title & Authors & Journal & pct & Type & USA \\
\hline $1(1)$ & $982(1064)$ & The Impact of Trade on Intra-industry Reallocation & Melitz & ecma-03 & $60 \%$ & $\mathrm{~T}$ & 1 \\
\hline $2(2)$ & $972(1054)$ & Gravity with Gravitas & Anderson ; van Wincoop & aer-03 & $100 \%$ & $\mathrm{D}$ & 1 \\
\hline $3(3)$ & $833(733)$ & Export versus FDI with Heterogeneous Firms & Helpman et al. & $\operatorname{aer}(\mathrm{s})-04$ & $100 \%$ & $\mathrm{D}$ & 0.83 \\
\hline $4(9)$ & $810(442)$ & Estimating Trade Flows & Helpman et al. & q.je-08 & $100 \%$ & $\mathrm{D}$ & 1 \\
\hline $5(13)$ & $651(355)$ & Market Size, Trade, and Productivity & Melitz ; Ottaviano & restud-08 & $100 \%$ & $\mathrm{~T}$ & 0.50 \\
\hline $6(94)$ & $549(93)$ & New Trade Models, Same Old Gains & Arkolakis et al. & aer-12 & $100 \%$ & $\mathrm{D}$ & 1 \\
\hline $7(14)$ & $505(340)$ & Globalization and the Gains from Variety & Broda ; Weinstein & qje-06 & $100 \%$ & $\mathrm{D}$ & 1 \\
\hline $8(4)$ & $467(575)$ & Globalization and the Inequality of Nations & Krugman ; Venables & qje-95 & $100 \%$ & $\mathrm{~T}$ & 0.50 \\
\hline $9(31)$ & $449(245)$ & Distorted Gravity & Chaney & $\operatorname{aer}(\mathrm{s})-08$ & $100 \%$ & $\mathrm{~T}$ & 1 \\
\hline $10(5)$ & $394(541)$ & Protection for Sale & Grossman ; Helpman & aer-94 & $50 \%$ & $\mathrm{~T}$ & 0.50 \\
\hline $11(7)$ & $383(472)$ & Exchange Rate Dynamics Redux & Obstfeld ; Rogoff & & $100 \%$ & $\mathrm{~T}$ & 1 \\
\hline $12(8)$ & $382(471)$ & National Borders Matter & McCallum & $\operatorname{aer}(\mathrm{s})-95$ & $100 \%$ & $\mathrm{D}$ & 0 \\
\hline $13(15)$ & $381(335)$ & Do We Really Know That the WTO Increases Trade & Rose & aer-04 & $100 \%$ & $\mathrm{D}$ & 1 \\
\hline $14(6)$ & $378(474)$ & Does Trade Cause Growth & Frankel ; Romer & aer-99 & $50 \%$ & $\mathrm{D}$ & 1 \\
\hline $15(10)$ & $369(371)$ & Technology, Geography, and Trade & Eaton ; Kortum & ecma-02 & $67 \%$ & $\mathrm{D}$ & 1 \\
\hline $16(20)$ & $355(299)$ & The Variety and Quality of a Nation's Exports & Hummels ; Klenow & aer-05 & $100 \%$ & $\mathrm{D}$ & 1 \\
\hline $17(11)$ & $341(369)$ & Plants and Productivity in International Trade & Bernard et al. & aer & $67 \%$ & $\mathrm{D}$ & 0.25 \\
\hline $18(12)$ & $295(369)$ & Do Domestic Firms Benefit from Direct Foreign Inve & Aitken ; Harrison & & $50 \%$ & $\mathrm{D}$ & 1 \\
\hline $19(21)$ & $282(297)$ & Estimating the Knowledge-Capital Model of the Mult & Carr et al. & $\operatorname{aer}(\mathrm{s})-01$ & $100 \%$ & $\mathrm{D}$ & 1 \\
\hline $20(97)$ & $275(88)$ & Labour Market Rigidities, Trade and Unemployment & Helpman ; Itskhoki & restud-10 & $100 \%$ & $\mathrm{~T}$ & 1 \\
\hline $21(42)$ & $273(172)$ & Comparative Advantage and Heterogeneous Firms & Bernard et al. & restud-07 & $100 \%$ & $\mathrm{~T}$ & 0.67 \\
\hline $22(27)$ & $264(265)$ & Order Flow and Exchange Rate Dynamics & Evans ; Lyons & & $100 \%$ & $\mathrm{D}$ & 1 \\
\hline $23(17)$ & $258(323)$ & The Twin Crises & Kaminsky ; Reinhart & aer-99 & $40 \%$ & $\mathrm{D}$ & 1 \\
\hline $24(28)$ & $258(259)$ & Fear of Floating & Calvo ; Reinhart & qje-02 & $50 \%$ & $\mathrm{~T}$ & 0.75 \\
\hline $25(18)$ & $250(320)$ & Real Exchange Rate Bel & Lothian ; Te & & $100 \%$ & $\mathrm{D}$ & 0.50 \\
\hline $26(58)$ & $239(131)$ & An Equilibrium Model of 'Global Imbalances' and Lo & Caballero et al. & aer-08 & $75 \%$ & $\mathrm{~T}$ & 1 \\
\hline $27(88)$ & $230(98)$ & Cultural Biases in Economic Exchange & Guiso et al. & qje-09 & $50 \%$ & $\mathrm{D}$ & 0.67 \\
\hline $28(22)$ & $230(283)$ & Exchange Rates and Fundamentals & Mark & aer-95 & $100 \%$ & $\mathrm{D}$ & 1 \\
\hline $29(38)$ & $227(200)$ & The Modern History of Exchange Rate Arrangements & Reinhart ; Rogoff & qje-04 & $50 \%$ & $\mathrm{D}$ & 1 \\
\hline $30(151)$ & $226(59)$ & An Anatomy of International Trade & Eaton et al. & ecma-11 & $50 \%$ & $\mathrm{D}$ & 0.67 \\
\hline $31(39)$ & $225(189)$ & Monetary Policy and Exchange Rate Volatility in a & Gali ; Monacelli & restud-05 & $67 \%$ & $\mathrm{~T}$ & 0 \\
\hline $32(25)$ & $219(270)$ & The Case of the Missing Trade and Other Mysteries & Trefler & aer-95 & $100 \%$ & $\mathrm{D}$ & 1 \\
\hline $33(365)$ & $218(10)$ & Tracing Value-Added and Double Counting in Gross E & Koopman et al. & & $40 \%$ & $\mathrm{~T}$ & 0.83 \\
\hline $33(365)$ & $218(10)$ & A Balls-and-Bins Model of Trade & Armenter ; Koren & $\operatorname{aer}(\mathrm{s})-14$ & $100 \%$ & $\mathrm{D}$ & 0.50 \\
\hline $35(16)$ & $217(325)$ & An Empirical Assessment of the Proximity-Concentra & Brainard & aer-97 & $100 \%$ & $\mathrm{D}$ & 1 \\
\hline $36(134)$ & $208(67)$ & Imported Intermediate Inputs and Domestic Product & Goldberg et al. & qje-10 & $67 \%$ & $\mathrm{D}$ & 0 \\
\hline $37(19)$ & $206(301)$ & Economic Integration and Endogenous Growth & Rivera-Batiz ; Romer & q.je-91 & $67 \%$ & $\mathrm{~T}$ & 1 \\
\hline $38(159)$ & $205(53)$ & Trade Liberalization, Exports, and Technology Upgr & Bustos & aer-11 & $40 \%$ & $\mathrm{D}$ & 0 \\
\hline $39(44)$ & $198(167)$ & Exchange Rates and Fundamentals & Engel ; West & jpe-05 & $100 \%$ & $\mathrm{D}$ & 1 \\
\hline $40(142)$ & $198(63)$ & Improved Access to Foreign Markets Raises Plant-Le & Lileeva ; Trefler & qje-10 & $67 \%$ & $\mathrm{D}$ & 0 \\
\hline $41(32)$ & $197(240)$ & Aid, Policies, and Growth & Burnside ; Dollar & aer-00 & $33 \%$ & $\mathrm{D}$ & 1 \\
\hline $42(46)$ & $195(164)$ & International Trade and Macroeconomic Dynamics wit & Ghironi ; Melitz & qje-05 & $100 \%$ & $\mathrm{~T}$ & 0.75 \\
\hline $43(23)$ & $193(282)$ & Target Zones and Exchange Rate Dynamics & Krugman & qje-91 & $100 \%$ & $\mathrm{~T}$ & 1 \\
\hline $44(36)$ & $192(208)$ & Can Vertical Specialization Explain the Growth of & $\mathrm{Yi}$ & jpe-03 & $75 \%$ & $\mathrm{D}$ & 1 \\
\hline $45(28)$ & $191(259)$ & Is Learning by Exporting Important & Clerides et al. & qje-98 & $50 \%$ & $\mathrm{D}$ & 0.67 \\
\hline $46(33)$ & $189(237)$ & An Economic Theory of GATT & Bagwell ; Staiger & aer-99 & $100 \%$ & $\mathrm{~T}$ & 1 \\
\hline $47(40)$ & $188(189)$ & Can Sticky Price Models Generate Volatile and Pers & Chari et al. & restud-02 & $67 \%$ & $\mathrm{D}$ & 1 \\
\hline $48(25)$ & $185(270)$ & Exchange Rates and Foreign Direct Investment & Froot ; Stein & qje-91 & $100 \%$ & $\mathrm{~T}$ & 1 \\
\hline $49(24)$ & $185(276)$ & Transactions Costs and Nonlinear Adjustment in Rea & Michael et al. & jpe-97 & $100 \%$ & $\mathrm{D}$ & 0 \\
\hline $50(49)$ & $182(160)$ & The Long and Short of the Canada-U.S. Free Trade A & Trefler & aer-04 & $80 \%$ & $\mathrm{D}$ & 0 \\
\hline
\end{tabular}




\subsection{Code H: Public Economics}

Table 36 reports the number of published articles with at least one JEL code H, for each journal and both the full period and our five subperiods. Publications in the AER and ECMA are decomposed in regular and shorter publications. It shows that out of 6,816 articles 581 have at least one JEL code H.

Table 36: Nb of articles with at least one JEL code $\mathrm{H}$

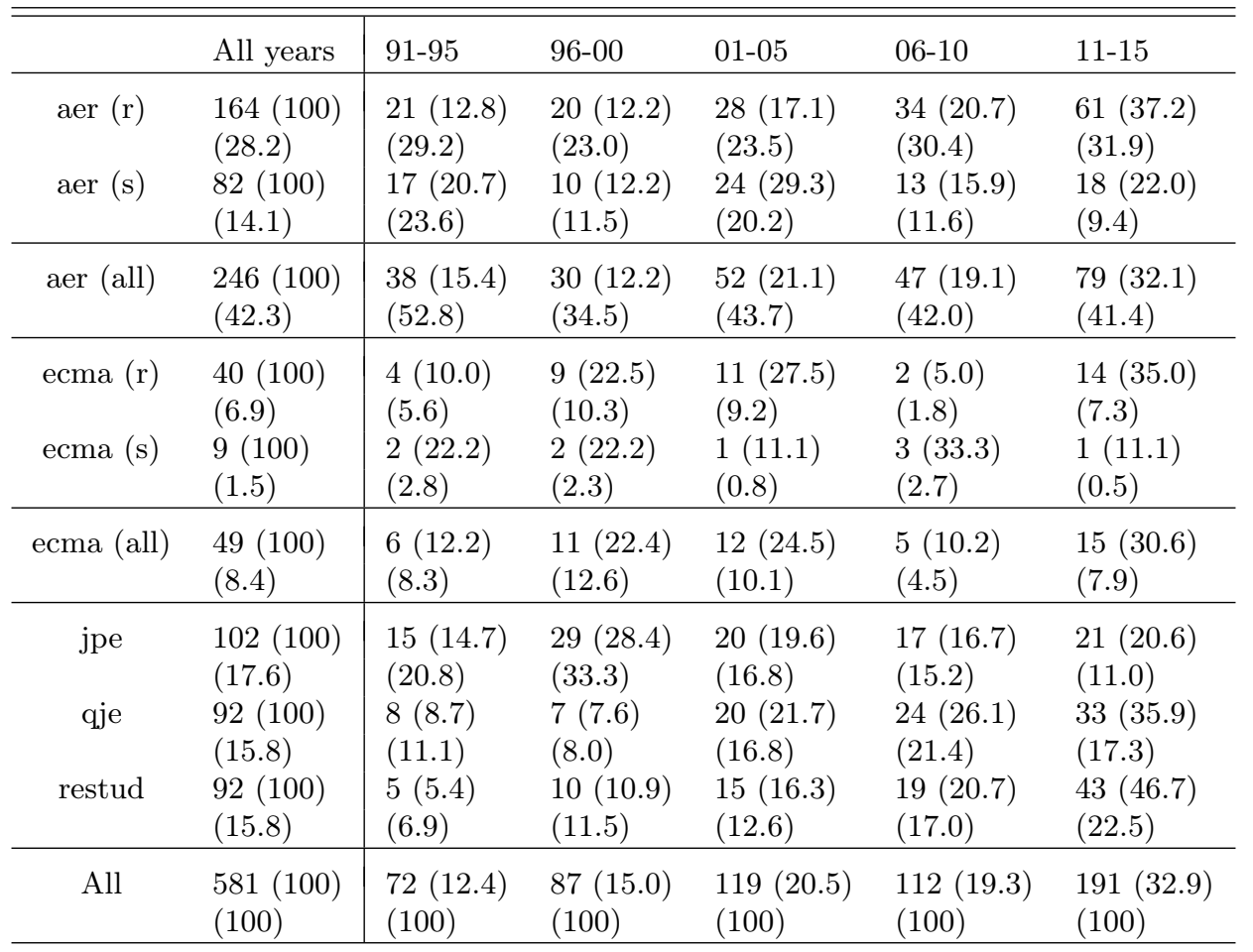

This table should be compared with Table 1. If all JEL codes were equally represented in each journal, the percentages of both tables would be the same. Public Economics articles are relatively more present in the AER (41.0 vs $32.9 \%$ ) and JPE (18.0 vs $15.0 \%$ ) but less in ECMA (8.8 vs $21 \%$ ). Table 37 summarizes the distributions of year-normalized citations for JEL code H per journal (year 2015 is excluded here). They should be compared to the ones of Table 9 .

Table 37: Year-normalized citations for JEL code $\mathrm{H}$

\begin{tabular}{lrrrrrrrrrrrrrr}
\hline \hline & $\mathrm{N}$ & mean & $\sigma$ & min & p5 & p10 & p25 & p50 & p75 & p90 & p95 & p99 & max \\
\hline aer (r) & 145 & 42.00 & 42.43 & 0 & 5 & 6 & 14 & 30 & 50 & 98 & 129 & 221 & 241 \\
aer (s) & 78 & 41.98 & 99.33 & 1 & 5 & 6 & 11 & 22 & 35 & 67 & 149 & 850 & 850 \\
\hline aer (all) & 223 & 42.00 & 67.75 & 0 & 5 & 6 & 13 & 26 & 46 & 90 & 129 & 221 & 850 \\
\hline ecma (r) & 39 & 35.90 & 39.62 & 1 & 2 & 4 & 12 & 22 & 45 & 96 & 159 & 165 & 165 \\
ecma (s) & 9 & 22.47 & 20.06 & 1 & 1 & 1 & 5 & 16 & 33 & 55 & 55 & 55 & 55 \\
\hline ecma (all) & 48 & 33.38 & 36.95 & 1 & 2 & 3 & 11 & 22 & 44 & 74 & 124 & 165 & 165 \\
\hline jpe & 98 & 36.30 & 45.23 & 0 & 2 & 4 & 11 & 23 & 47 & 77 & 131 & 318 & 318 \\
qje & 86 & 51.75 & 45.23 & 0 & 5 & 7 & 16 & 39 & 81 & 116 & 150 & 186 & 186 \\
restud & 89 & 23.29 & 23.41 & 0 & 2 & 3 & 8 & 17 & 31 & 48 & 65 & 124 & 124 \\
\hline All & 544 & 38.69 & 53.32 & 0 & 3 & 5 & 11 & 25 & 47 & 92 & 124 & 198 & 850 \\
\hline
\end{tabular}

Table 38 lists the top 50 articles with at least one JEL code H. See for a precise definition of the different variables Section 6.1. 
Table 38: Top 25 articles for $T=1991-2014$ Code H, normalized per year

\begin{tabular}{|c|c|c|c|c|c|c|c|}
\hline$\widetilde{R}(\mathrm{R})$ & $\widetilde{C_{i}}\left(C_{i}\right)$ & Title & Authors & Journal & pct & Type & USA \\
\hline $1(1)$ & $850(1032)$ & Cooperation and Punishment in Public Goods Experim & Fehr ; Gachter & $\operatorname{aer}(\mathrm{s})-00$ & $100 \%$ & $\mathrm{E}$ & 0 \\
\hline $2(2)$ & $318(431)$ & Why Do More Open Economies Have Bigger Governments & Rodrik & jpe-98 & $67 \%$ & $\mathrm{D}$ & 1 \\
\hline $3(3)$ & $241(297)$ & Cooperation in Public-Goods Experiments & Andreoni & aer-95 & $100 \%$ & $\mathrm{E}$ & 1 \\
\hline $4(29)$ & $221(94)$ & Salience and Taxation & Chetty et al. & aer-09 & $50 \%$ & $\mathrm{D}$ & 1 \\
\hline $5(4)$ & $200(275)$ & State Responses to Fiscal Crises & Poterba & jpe-94 & $100 \%$ & $\mathrm{~T}$ & 1 \\
\hline $6(11)$ & $198(167)$ & Does Britain or the United States Have the Right G & Parry ; Small & $\operatorname{aer}(\mathrm{s})-05$ & $100 \%$ & $\mathrm{D}$ & 1 \\
\hline $7(5)$ & $186(253)$ & The Behavior of U.S. Public Debt and Deficits & Bohn & qje-98 & $100 \%$ & $\mathrm{D}$ & 1 \\
\hline $8(142)$ & $186(32)$ & The Oregon Health Insurance Experiment & Finkelstein et al. & q.je-12 & $25 \%$ & $\mathrm{D}$ & 0.13 \\
\hline $9(75)$ & $181(58)$ & Beyond Markets and States & Ostrom & aer-10 & $25 \%$ & $\mathrm{~T}$ & 1 \\
\hline $10(7)$ & $171(211)$ & Incumbent Behavior & Besley ; Case & aer-95 & $50 \%$ & $\mathrm{D}$ & 1 \\
\hline $11(46)$ & $168(71)$ & Taxing Capital & Conesa et al. & aer-09 & $75 \%$ & $\mathrm{D}$ & 0.67 \\
\hline $12(160)$ & $165(28)$ & Bounds on Elasticities with Optimization Frictions & Chetty & ecma-12 & $50 \%$ & $\mathrm{D}$ & 1 \\
\hline $13(6)$ & $160(215)$ & Jeux Sans Frontieres & Kanbur ; Keen & aer-93 & $100 \%$ & $\mathrm{~T}$ & 0.50 \\
\hline $14(108)$ & $159(41)$ & Unwilling or Unable to Cheat & Kleven et al. & ecma-11 & $67 \%$ & $\mathrm{D}$ & 0.20 \\
\hline $15(18)$ & $156(132)$ & Ethnic Polarization, Potential Conflict, and Civil & Montalvo ; Reynal-Querol & aer $(\mathrm{s})-05$ & $50 \%$ & $\mathrm{~T}$ & 0.50 \\
\hline $16(58)$ & $156(66)$ & E-ZTax & Finkelstein & qje-09 & $100 \%$ & $\mathrm{D}$ & 1 \\
\hline $17(8)$ & $151(189)$ & Public Goods and Ethnic Divisions & Alesina et al. & qje-99 & $33 \%$ & $\mathrm{D}$ & 1 \\
\hline $18(92)$ & $150(48)$ & Teacher Quality in Educational Production & Rothstein & qje-10 & $33 \%$ & $\mathrm{D}$ & 1 \\
\hline $19(94)$ & $149(48)$ & Social Preferences, Beliefs, and the Dynamics of F & Fischbacher ; Gachter & $\operatorname{aer}(\mathrm{s})-10$ & $25 \%$ & $\mathrm{E}$ & 0 \\
\hline $20(9)$ & $146(180)$ & The Effect of Marginal Tax Rates on Taxable Income & Feldstein & jpe-95 & $100 \%$ & $\mathrm{D}$ & 1 \\
\hline $21(188)$ & $137(23)$ & The Impact of Family Income on Child Achievement & Dahl ; Lochner & aer-12 & $40 \%$ & $\mathrm{D}$ & 0.50 \\
\hline $22(128)$ & $132(34)$ & When Is the Government Spending Multiplier Large & Christiano et al. & jpe-11 & $25 \%$ & $\mathrm{~T}$ & 1 \\
\hline $23(129)$ & $131(34)$ & Can Hearts and Minds Be Bought & Berman et al. & jpe-11 & $67 \%$ & $\mathrm{D}$ & 1 \\
\hline $24(132)$ & $130(34)$ & Identifying Government Spending Shocks & Ramey & qje-11 & $25 \%$ & $\mathrm{D}$ & 1 \\
\hline $25(109)$ & $129(41)$ & The Macroeconomic Effects of Tax Changes & Romer ; Romer & aer-10 & $25 \%$ & $\mathrm{D}$ & 1 \\
\hline $26(26)$ & $128(113)$ & The Regulation of Labor & Botero et al. & qje-04 & $25 \%$ & $\mathrm{D}$ & 1 \\
\hline $27(13)$ & $127(156)$ & Warm-Glow versus Cold-Prickle & Andreoni & qje-95 & $100 \%$ & $\mathrm{E}$ & 1 \\
\hline $28(379)$ & $124(6)$ & Optimal Taxes on Fossil Fuel in General Equilibriu & Golosov et al. & ecma-14 & $29 \%$ & $\mathrm{D}$ & 0.50 \\
\hline $29(19)$ & $124(131)$ & Using Elasticities to Derive Optimal Income Tax Ra & Saez & restud-01 & $100 \%$ & $\mathrm{D}$ & 1 \\
\hline $30(37)$ & $120(81)$ & Green Markets and Private Provision of Public Good & Kotchen & jpe-06 & $100 \%$ & $\mathrm{~T}$ & 1 \\
\hline $31(21)$ & $116(126)$ & Monetary and Nonmonetary Punishment in the Volunta & Masclet et al. & $\operatorname{aer}(\mathrm{s})-03$ & $50 \%$ & $\mathrm{~T}$ & 0 \\
\hline $32(289)$ & $116(12)$ & Using Notches to Uncover Optimization Frictions an & Kleven ; Waseem & qje-13 & $60 \%$ & $\mathrm{D}$ & 0 \\
\hline $33(10)$ & $115(168)$ & Willingness to Pay and Willingness to Accept & Hanemann & $\operatorname{aer}(\mathrm{s})-91$ & $50 \%$ & $\mathrm{~T}$ & 1 \\
\hline $34(217)$ & $115(20)$ & Comparison Friction & Kling et al. & qje-12 & $50 \%$ & $\mathrm{D}$ & 0.80 \\
\hline $35(151)$ & $113(29)$ & Adjustment Costs, Firm Responses, and Micro vs. Ma & Chetty et al. & qje-11 & $67 \%$ & $\mathrm{D}$ & 1 \\
\hline $36(22)$ & $113(122)$ & Optimal Indirect and Capital Taxation & Golosov et al. & restud-03 & $100 \%$ & $\mathrm{~T}$ & 1 \\
\hline $37(12)$ & $110(165)$ & The Proper Scope of Government & Hart et al. & qje-97 & $50 \%$ & $\mathrm{~T}$ & 1 \\
\hline $38(15)$ & $109(148)$ & Optimal Income Taxation & Diamond & aer-98 & $100 \%$ & $\mathrm{D}$ & 1 \\
\hline $39(392)$ & $109(5)$ & Measuring the Impacts of Teachers II & Chetty et al. & aer-14 & $25 \%$ & $\mathrm{D}$ & 1 \\
\hline $40(25)$ & $108(114)$ & Gamma Discounting & Weitzman & aer-01 & $50 \%$ & $\mathrm{~T}$ & 1 \\
\hline $41(13)$ & $107(156)$ & Income Redistribution in a Common Labor Market & Wildasin & aer-91 & $100 \%$ & $\mathrm{~T}$ & 1 \\
\hline $42(27)$ & $107(107)$ & Optimal Income Transfer Programs & Saez & qje-02 & $75 \%$ & $\mathrm{~T}$ & 1 \\
\hline $43(236)$ & $104(18)$ & The Aggregate Demand for Treasury Debt & Krishnamurthy ; Vissing & jpe-12 & $33 \%$ & $\mathrm{~T}$ & 1 \\
\hline $44(16)$ & $103(140)$ & Federalism and the Soft Budget Constraint & Qian ; Roland & aer-98 & $75 \%$ & $\mathrm{D}$ & 0.50 \\
\hline $45(104)$ & $103(44)$ & The Origins of State Capacity & Besley ; Persson & aer-09 & $40 \%$ & $\mathrm{D}$ & 0 \\
\hline $46(300)$ & $103(11)$ & The Missing Wealth of Nations & Zucman & q.je-13 & $67 \%$ & $\mathrm{D}$ & 0 \\
\hline $47(23)$ & $100(121)$ & Comparative Politics and Public Finance & Persson et al. & jpe-00 & $67 \%$ & $\mathrm{D}$ & 0 \\
\hline $48(405)$ & $98(5)$ & Measuring the Impacts of Teachers I & Chetty et al. & aer-14 & $25 \%$ & $\mathrm{D}$ & 1 \\
\hline $49(307)$ & $96(10)$ & A Theory of Optimal Inheritance Taxation & Piketty ; Saez & ecma-13 & $67 \%$ & $\mathrm{D}$ & 0.50 \\
\hline $50(39)$ & $95(80)$ & Dividend Taxes and Corporate Behavior & Chetty ; Saez & qje-05 & $75 \%$ & $\mathrm{D}$ & 1 \\
\hline
\end{tabular}




\subsection{Code I: Health, Education, and Welfare}

Table 39 reports the number of published articles with at least one JEL code I, for each journal and both the full period and our five subperiods. Publications in the AER and ECMA are decomposed in regular and shorter publications. It shows that out of 6,816 articles 561 have at least one JEL code I.

Table 39: Nb of articles with at least one JEL code I

\begin{tabular}{|c|c|c|c|c|c|c|}
\hline & All years & $91-95$ & $96-00$ & 01-05 & $06-10$ & $11-15$ \\
\hline $\begin{array}{l}\text { aer }(\mathrm{r}) \\
\text { aer }(\mathrm{s})\end{array}$ & $\begin{array}{l}154(100) \\
(27.5) \\
76(100) \\
(13.5) \\
\end{array}$ & $\begin{array}{l}12(7.8) \\
(22.6) \\
8(10.5) \\
(15.1) \\
\end{array}$ & $\begin{array}{l}11(7.1) \\
(16.4) \\
10(13.2) \\
(14.9) \\
\end{array}$ & $\begin{array}{l}24(15.6) \\
(20.0) \\
19(25.0) \\
(15.8) \\
\end{array}$ & $\begin{array}{l}30(19.5) \\
(23.1) \\
20(26.3) \\
(15.4)\end{array}$ & $\begin{array}{l}77(50.0) \\
(40.3) \\
19(25.0) \\
(9.9) \\
\end{array}$ \\
\hline aer (all) & $\begin{array}{l}230(100) \\
(41.0)\end{array}$ & $\begin{array}{l}20(8.7) \\
(37.7)\end{array}$ & $\begin{array}{l}21(9.1) \\
(31.3)\end{array}$ & $\begin{array}{l}43(18.7) \\
(35.8)\end{array}$ & $\begin{array}{l}50(21.7) \\
(38.5) \\
\end{array}$ & $\begin{array}{l}96(41.7) \\
(50.3)\end{array}$ \\
\hline $\begin{array}{l}\text { ecma (r) } \\
\text { ecma (s) }\end{array}$ & $\begin{array}{l}41(100) \\
(7.3) \\
11(100) \\
(2.0) \\
\end{array}$ & $\begin{array}{l}3(7.3) \\
(5.7) \\
2(18.2) \\
(3.8) \\
\end{array}$ & $\begin{array}{l}6(14.6) \\
(9.0) \\
.(.) \\
(.) \\
\end{array}$ & $\begin{array}{l}11(26.8) \\
(9.2) \\
4(36.4) \\
(3.3) \\
\end{array}$ & $\begin{array}{l}7(17.1) \\
(5.4) \\
2(18.2) \\
(1.5) \\
\end{array}$ & $\begin{array}{l}14(34.1) \\
(7.3) \\
3(27.3) \\
(1.6) \\
\end{array}$ \\
\hline ecma (all) & $\begin{array}{l}52(100) \\
(9.3)\end{array}$ & $\begin{array}{l}5(9.6) \\
(9.4) \\
\end{array}$ & $\begin{array}{l}6(11.5) \\
(9.0)\end{array}$ & $\begin{array}{l}15(28.8) \\
(12.5)\end{array}$ & $\begin{array}{l}9(17.3) \\
(6.9) \\
\end{array}$ & $\begin{array}{l}17(32.7) \\
(8.9)\end{array}$ \\
\hline jpe & $\begin{array}{l}87(100) \\
(15.5)\end{array}$ & $\begin{array}{l}17(19.5) \\
(32.1)\end{array}$ & $\begin{array}{l}12(13.8) \\
(17.9)\end{array}$ & $\begin{array}{l}23(26.4) \\
(19.2)\end{array}$ & $\begin{array}{l}20(23.0) \\
(15.4)\end{array}$ & $\begin{array}{l}15(17.2) \\
(7.9)\end{array}$ \\
\hline qje & $\begin{array}{l}137(100) \\
(24.4)\end{array}$ & $\begin{array}{l}9(6.6) \\
(17.0)\end{array}$ & $\begin{array}{l}23(16.8) \\
(34.3)\end{array}$ & $\begin{array}{l}30(21.9) \\
(25.0)\end{array}$ & $\begin{array}{l}39(28.5) \\
(30.0)\end{array}$ & $\begin{array}{l}36(26.3) \\
(18.8)\end{array}$ \\
\hline restud & $\begin{array}{l}55(100) \\
(9.8)\end{array}$ & $\begin{array}{l}2(3.6) \\
(3.8)\end{array}$ & $\begin{array}{l}5(9.1) \\
(7.5)\end{array}$ & $\begin{array}{l}9(16.4) \\
(7.5)\end{array}$ & $\begin{array}{l}12(21.8) \\
(9.2)\end{array}$ & $\begin{array}{l}27(49.1) \\
(14.1)\end{array}$ \\
\hline All & $\begin{array}{l}561(100) \\
(100)\end{array}$ & $\begin{array}{l}53(9.4) \\
(100)\end{array}$ & $\begin{array}{l}67(11.9) \\
(100)\end{array}$ & $\begin{array}{l}120(21.4) \\
(100)\end{array}$ & $\begin{array}{l}130(23.2) \\
(100)\end{array}$ & $\begin{array}{l}191(34.0) \\
(100)\end{array}$ \\
\hline
\end{tabular}

This table should be compared with Table 1. If all JEL codes were equally represented in each journal, the percentages of both tables would be the same. Code I articles are relatively more present in AER (39.8 vs $32.9 \%$ ) and qje (25.2 vs $15.4 \%$ ) but less in ECMA (9 vs 21\%) and RESTUD (10.2 vs 15.7\%). Table 40 summarizes the distributions of year-normalized citations for JEL code I per journal (year 2015 is excluded here). They should be compared to the ones of Table 9 .

Table 40: Year-normalized citations for JEL code I

\begin{tabular}{lrlllrrrrrrrrr}
\hline \hline & $\mathrm{N}$ & mean & $\sigma$ & min & $\mathrm{p} 5$ & $\mathrm{p} 10$ & $\mathrm{p} 25$ & $\mathrm{p} 50$ & $\mathrm{p} 75$ & $\mathrm{p} 90$ & $\mathrm{p} 95$ & $\mathrm{p} 99$ & $\mathrm{max}$ \\
\hline aer (r) & 130 & 56.80 & 53.46 & 2 & 8 & 12 & 22 & 42 & 74 & 113 & 184 & 225 & 368 \\
aer (s) & 74 & 36.33 & 31.94 & 0 & 3 & 7 & 14 & 24 & 54 & 80 & 111 & 159 & 159 \\
\hline aer (all) & 204 & 49.38 & 47.75 & 0 & 7 & 9 & 19 & 35 & 68 & 98 & 137 & 222 & 368 \\
\hline ecma (r) & 37 & 68.57 & 126.50 & 2 & 3 & 6 & 11 & 31 & 80 & 164 & 289 & 733 & 733 \\
ecma (s) & 9 & 28.29 & 21.35 & 3 & 3 & 3 & 13 & 16 & 46 & 59 & 59 & 59 & 59 \\
\hline ecma (all) & 46 & 60.69 & 114.65 & 2 & 3 & 6 & 11 & 30 & 59 & 104 & 173 & 733 & 733 \\
\hline jpe & 81 & 47.12 & 46.57 & 2 & 5 & 7 & 14 & 30 & 60 & 114 & 140 & 200 & 200 \\
qje & 129 & 72.14 & 77.64 & 0 & 10 & 13 & 22 & 44 & 101 & 174 & 198 & 313 & 557 \\
restud & 52 & 23.55 & 30.74 & 0 & 0 & 2 & 7 & 16 & 29 & 43 & 53 & 189 & 189 \\
\hline All & 512 & 53.15 & 64.84 & 0 & 5 & 8 & 16 & 32 & 67 & 124 & 174 & 289 & 733 \\
\hline
\end{tabular}

Table 41 lists the top 50 articles with at least one JEL code I. See for a precise definition of the different variables Section 6.1. 
Table 41: Top 50 articles for $T=1991-2014$ Code I, normalized per year

\begin{tabular}{|c|c|c|c|c|c|c|c|}
\hline$\widetilde{R}(\mathrm{R})$ & $\widetilde{C_{i}}\left(C_{i}\right)$ & Title & Authors & Journal & pct & Type & USA \\
\hline $1(1)$ & $733(617)$ & Teachers, Schools, and Academic Achievement & Rivkin et al. & ecma-05 & $100 \%$ & $\mathrm{D}$ & 0.67 \\
\hline $2(50)$ & $557(95)$ & The Oregon Health Insurance Experiment & Finkelstein et al. & qje-12 & $75 \%$ & $\mathrm{D}$ & 0.13 \\
\hline $3(2)$ & $368(388)$ & The Colonial Origins of Comparative Development & Acemoglu et al. & aer-01 & $20 \%$ & $\mathrm{D}$ & 1 \\
\hline $4(15)$ & $313(197)$ & From the Cradle to the Labor Market & Black et al. & q.je-07 & $100 \%$ & $\mathrm{D}$ & 0.33 \\
\hline $5(3)$ & $290(363)$ & Using Maimonides' Rule to Estimate the Effect of $\mathrm{C}$ & Angrist ; Lavy & qje-99 & $100 \%$ & $\mathrm{D}$ & 0.50 \\
\hline $6(9)$ & $289(254)$ & Worms & Miguel ; Kremer & ecma-04 & $67 \%$ & $\mathrm{D}$ & 1 \\
\hline $7(4)$ & $281(352)$ & Experimental Estimates of Education Production Fun & Krueger & qje-99 & $100 \%$ & $\mathrm{E}$ & 1 \\
\hline $8(5)$ & $235(294)$ & Do Better Schools Matter & Black & q.je-99 & $100 \%$ & $\mathrm{D}$ & 1 \\
\hline $9(222)$ & $225(23)$ & Understanding the Mechanisms through Which an Infl & Heckman et al. & aer-13 & $60 \%$ & $\mathrm{E}$ & 0.83 \\
\hline $10(6)$ & $222(273)$ & Does Head Start Make a Difference & Currie ; Thomas & aer-95 & $100 \%$ & $\mathrm{D}$ & 1 \\
\hline $11(230)$ & $217(23)$ & The Effect of Education on Adult Mortality and Hea & Clark ; Royer & aer-13 & $75 \%$ & $\mathrm{D}$ & 1 \\
\hline $12(12)$ & $201(212)$ & Peer Effects with Random Assignment & Sacerdote & qje-01 & $50 \%$ & $\mathrm{D}$ & 1 \\
\hline $13(7)$ & $200(272)$ & Life Cycle Schooling and Dynamic Selection Bias & Cameron ; Heckman & jpe-98 & $100 \%$ & $\mathrm{D}$ & 1 \\
\hline $14(10)$ & $198(240)$ & Are Recessions Good for Your Health & Ruhm & qje-00 & $50 \%$ & $\mathrm{D}$ & 1 \\
\hline $15(16)$ & $194(195)$ & Longer-Term Effects of Head Start & Garces et al. & aer-02 & $100 \%$ & $\mathrm{D}$ & 0.67 \\
\hline $16(117)$ & $193(50)$ & Accountability and Flexibility in Public Schools & Abdulkadiroglu et al. & qje-11 & $100 \%$ & $\mathrm{D}$ & 1 \\
\hline $17(28)$ & $189(160)$ & The Relationship between Education and Adult Morta & Lleras-Muney & restud-05 & $50 \%$ & $\mathrm{D}$ & 1 \\
\hline $18(120)$ & $189(49)$ & How Does Your Kindergarten Classroom Affect Your E & Chetty et al. & qje-11 & $50 \%$ & $\mathrm{E}$ & 1 \\
\hline $19(25)$ & $186(164)$ & Kidney Exchange & Roth et al. & qje-04 & $100 \%$ & $\mathrm{~T}$ & 0.33 \\
\hline $20(13)$ & $185(201)$ & Is More Information Better & Dranove et al. & jpe-03 & $100 \%$ & $\mathrm{D}$ & 0.25 \\
\hline $21(38)$ & $184(124)$ & Estimating Average and Local Average Treatment Eff & Oreopoulos & aer-06 & $100 \%$ & $\mathrm{D}$ & 0 \\
\hline $22(31)$ & $184(155)$ & The Quantity and Quality of Life and the Evolution & Becker et al. & aer-05 & $100 \%$ & $\mathrm{D}$ & 0.83 \\
\hline $23(183)$ & $181(31)$ & The Role of Application Assistance and Information & Bettinger et al. & qje-12 & $67 \%$ & $\mathrm{D}$ & 0.50 \\
\hline $24(8)$ & $180(263)$ & Health Behavior, Health Knowledge, and Schooling & Kenkel & jpe-91 & $100 \%$ & $\mathrm{D}$ & 1 \\
\hline $25(18)$ & $175(190)$ & Rotten Apples & Jacob ; Levitt & q.je-03 & $100 \%$ & $\mathrm{D}$ & 1 \\
\hline $26(11)$ & $174(223)$ & Do Doctors Practice Defensive Medicine & Kessler ; McClellan & qje-96 & $100 \%$ & $\mathrm{D}$ & 1 \\
\hline $27(41)$ & $173(109)$ & Experimental Analysis of Neighborhood Effects & Kling et al. & ecma-07 & $25 \%$ & $\mathrm{D}$ & 1 \\
\hline $28(135)$ & $166(43)$ & Financial Incentives and Student Achievement & Fryer & q.je-11 & $100 \%$ & $\mathrm{D}$ & 1 \\
\hline $29(34)$ & $165(139)$ & Neighbors as Negatives & Luttmer & qje-05 & $33 \%$ & $\mathrm{D}$ & 1 \\
\hline $30(14)$ & $165(200)$ & The Effects of Class Size on Student Achievement & Hoxby & q.je-00 & $100 \%$ & $\mathrm{D}$ & 1 \\
\hline $31(113)$ & $164(52)$ & Estimating the Technology of Cognitive and Noncogn & Cunha et al. & ecma-10 & $33 \%$ & $\mathrm{D}$ & 0.83 \\
\hline $32(59)$ & $159(87)$ & The Impact of Nearly Universal Insurance Coverage & Card et al. & $\operatorname{aer}(\mathrm{s})-08$ & $100 \%$ & $\mathrm{~T}$ & 1 \\
\hline $33(46)$ & $159(100)$ & Does Head Start Improve Children's Life Chances & Ludwig ; Miller & qje-07 & $67 \%$ & $\mathrm{D}$ & 1 \\
\hline $34(123)$ & $150(48)$ & Teacher Quality in Educational Production & Rothstein & qje-10 & $33 \%$ & $\mathrm{D}$ & 1 \\
\hline $35(19)$ & $147(181)$ & Finishing High School and Starting College & Evans ; Schwab & q.je-95 & $100 \%$ & $\mathrm{D}$ & 1 \\
\hline $36(21)$ & $147(178)$ & Is Hospital Competition Socially Wasteful & Kessler ; McClellan & qje-00 & $100 \%$ & $\mathrm{D}$ & 1 \\
\hline $37(131)$ & $144(46)$ & Does Professor Quality Matter & Carrell ; West & jpe-10 & $100 \%$ & $\mathrm{D}$ & 1 \\
\hline $38(33)$ & $142(143)$ & Economic Status and Health in Childhood & Case et al. & aer-02 & $33 \%$ & $\mathrm{~T}$ & 0 \\
\hline $39(17)$ & $140(192)$ & Economic Growth, Population Theory, and Physiology & Fogel & aer-94 & $50 \%$ & $\mathrm{~T}$ & 1 \\
\hline $40(20)$ & $140(179)$ & Saving Babies & Currie ; Gruber & jpe-96 & $100 \%$ & $\mathrm{D}$ & 1 \\
\hline $41(225)$ & $137(23)$ & The Impact of Family Income on Child Achievement & Dahl ; Lochner & aer-12 & $40 \%$ & $\mathrm{D}$ & 0.50 \\
\hline $42(160)$ & $136(35)$ & Cash or Condition & Baird et al. & q.je-11 & $67 \%$ & $\mathrm{E}$ & 1 \\
\hline $43(56)$ & $134(91)$ & Is the 1918 Influenza Pandemic Over & Almond & jpe-06 & $50 \%$ & $\mathrm{D}$ & 1 \\
\hline $44(78)$ & $134(73)$ & Sources of Advantageous Selection & Fang et al. & jpe-08 & $100 \%$ & $\mathrm{~T}$ & 0.83 \\
\hline $45(64)$ & $132(83)$ & Disease and Development & Bleakley & qje-07 & $50 \%$ & $\mathrm{D}$ & 1 \\
\hline $46(22)$ & $130(177)$ & Competition between Private and Public Schools, Vo & Epple ; Romano & aer-98 & $67 \%$ & $\mathrm{~T}$ & 1 \\
\hline $47(107)$ & $130(55)$ & Does Medicare Save Lives & Card et al. & q.je-09 & $100 \%$ & $\mathrm{D}$ & 1 \\
\hline $48(29)$ & $128(158)$ & Precautionary Saving and Social Insurance & Hubbard et al. & jpe-95 & $50 \%$ & $\mathrm{D}$ & 1 \\
\hline $49(144)$ & $128(41)$ & Free Distribution or Cost-Sharing & Cohen ; Dupas & qje-10 & $50 \%$ & $\mathrm{D}$ & 1 \\
\hline $50(23)$ & $124(169)$ & Private School Vouchers and Student Achievement & Rouse & q.je-98 & $100 \%$ & $\mathrm{D}$ & 1 \\
\hline
\end{tabular}




\subsection{Code R: Urban, Rural, Regional, Real Estate, and Transportation Economics}

Table 42 reports the number of published articles with at least one JEL code R, for each journal and both the full period and our five subperiods. Publications in the AER and ECMA are decomposed in regular and shorter publications. It shows that out of 6,816 articles 276 have at least one JEL code R.

Table 42: Nb of articles with at least one JEL code $\mathrm{R}$

\begin{tabular}{|c|c|c|c|c|c|c|}
\hline & All years & $91-95$ & 96-00 & 01-05 & 06-10 & $11-15$ \\
\hline $\begin{array}{l}\text { aer }(\mathrm{r}) \\
\operatorname{aer}(\mathrm{s})\end{array}$ & $\begin{array}{l}77(100) \\
(27.9) \\
36(100) \\
(13.0) \\
\end{array}$ & $\begin{array}{l}3(3.9) \\
(11.5) \\
6(16.7) \\
(23.1) \\
\end{array}$ & $\begin{array}{l}8(10.4) \\
(26.7) \\
3(8.3) \\
(10.0) \\
\end{array}$ & $\begin{array}{l}14(18.2) \\
(22.6) \\
11(30.6) \\
(17.7) \\
\end{array}$ & $\begin{array}{l}12(15.6) \\
(21.4) \\
8(22.2) \\
(14.3) \\
\end{array}$ & $\begin{array}{l}40(51.9) \\
(39.2) \\
8(22.2) \\
(7.8) \\
\end{array}$ \\
\hline aer (all) & $\begin{array}{l}113(100) \\
(40.9)\end{array}$ & $\begin{array}{l}9(8.0) \\
(34.6) \\
\end{array}$ & $\begin{array}{l}11(9.7) \\
(36.7)\end{array}$ & $\begin{array}{l}25(22.1) \\
(40.3)\end{array}$ & $\begin{array}{l}20(17.7) \\
(35.7)\end{array}$ & $\begin{array}{l}48(42.5) \\
(47.1)\end{array}$ \\
\hline $\begin{array}{l}\text { ecma }(r) \\
\text { ecma }(s)\end{array}$ & $\begin{array}{l}19(100) \\
(6.9) \\
1(100) \\
(0.4) \\
\end{array}$ & $\begin{array}{l}2(10.5) \\
(7.7) \\
.(.) \\
(.) \\
\end{array}$ & $\begin{array}{l}.(.) \\
(.) \\
\cdot(.) \\
(.)\end{array}$ & $\begin{array}{l}4(21.1) \\
(6.5) \\
1(100.0) \\
(1.6) \\
\end{array}$ & $\begin{array}{l}3(15.8) \\
(5.4) \\
.(.) \\
(.) \\
\end{array}$ & $\begin{array}{l}10(52.6) \\
(9.8) \\
.(.) \\
(.) \\
\end{array}$ \\
\hline ecma (all) & $\begin{array}{l}20(100) \\
(7.2)\end{array}$ & $\begin{array}{l}2(10.0) \\
(7.7)\end{array}$ & $\begin{array}{l}.(.) \\
(.)\end{array}$ & $\begin{array}{l}5(25.0) \\
(8.1)\end{array}$ & $\begin{array}{l}3(15.0) \\
(5.4)\end{array}$ & $\begin{array}{l}10(50.0) \\
(9.8)\end{array}$ \\
\hline jpe & $\begin{array}{l}51(100) \\
(18.5)\end{array}$ & $\begin{array}{l}8(15.7) \\
(30.8)\end{array}$ & $\begin{array}{l}9(17.6) \\
(30.0)\end{array}$ & $\begin{array}{l}15(29.4) \\
(24.2)\end{array}$ & $\begin{array}{l}11(21.6) \\
(19.6)\end{array}$ & $\begin{array}{l}8(15.7) \\
(7.8)\end{array}$ \\
\hline qje & $\begin{array}{l}63(100) \\
(22.8)\end{array}$ & $\begin{array}{l}7(11.1) \\
(26.9)\end{array}$ & $\begin{array}{l}8(12.7) \\
(26.7)\end{array}$ & $\begin{array}{l}14(22.2) \\
(22.6)\end{array}$ & $\begin{array}{l}13(20.6) \\
(23.2)\end{array}$ & $\begin{array}{l}21(33.3) \\
(20.6)\end{array}$ \\
\hline restud & $\begin{array}{l}29(100) \\
(10.5)\end{array}$ & $\begin{array}{l}.(.) \\
(.)\end{array}$ & $\begin{array}{l}2(6.9) \\
(6.7)\end{array}$ & $\begin{array}{l}3(10.3) \\
(4.8)\end{array}$ & $\begin{array}{l}9(31.0) \\
(16.1)\end{array}$ & $\begin{array}{l}15(51.7) \\
(14.7)\end{array}$ \\
\hline All & $\begin{array}{l}276(100) \\
(100)\end{array}$ & $\begin{array}{l}26(9.4) \\
(100)\end{array}$ & $\begin{array}{l}30(10.9) \\
(100)\end{array}$ & $\begin{array}{l}62(22.5) \\
(100)\end{array}$ & $\begin{array}{l}56(20.3) \\
(100)\end{array}$ & $\begin{array}{l}102(37.0) \\
(100)\end{array}$ \\
\hline
\end{tabular}

This table should be compared with Table 1. If all JEL codes were equally represented in each journal, the percentages of both tables would be the same. Code $\mathrm{R}$ articles are relatively more present in AER (39.5 vs $32.9 \%$ ), JPE (19.0 vs $15.0 \%$ ) and QJE (23.2 vs $15.4 \%$ ) but less in ECMA (7.6 vs $21 \%$ ) and RESTUD (10.6 vs $15.7 \%$ ). Table 43 summarizes the distributions of year-normalized citations for JEL code R per journal (year 2015 is excluded here). They should be compared to the ones of Table 9.

Table 43: Year-normalized citations for JEL code $\mathrm{R}$

\begin{tabular}{lrrrrrrrrrrrrrr}
\hline \hline & $\mathrm{N}$ & mean & $\sigma$ & min & $\mathrm{p} 5$ & $\mathrm{p} 10$ & $\mathrm{p} 25$ & $\mathrm{p} 50$ & $\mathrm{p} 75$ & $\mathrm{p} 90$ & $\mathrm{p} 95$ & $\mathrm{p} 99$ & $\mathrm{max}$ \\
\hline aer (r) & 68 & 50.82 & 63.26 & 3 & 6 & 7 & 13 & 24 & 60 & 159 & 180 & 337 & 337 \\
aer (s) & 36 & 59.24 & 99.61 & 2 & 3 & 7 & 16 & 22 & 61 & 154 & 310 & 512 & 512 \\
\hline aer (all) & 104 & 53.74 & 77.40 & 2 & 6 & 7 & 14 & 23 & 61 & 154 & 202 & 337 & 512 \\
\hline ecma (r) & 19 & 69.91 & 83.73 & 0 & 0 & 3 & 22 & 38 & 87 & 184 & 346 & 346 & 346 \\
ecma (s) & 1 & 198.30 &. & 198 & 198 & 198 & 198 & 198 & 198 & 198 & 198 & 198 & 198 \\
\hline ecma (all) & 20 & 76.33 & 86.41 & 0 & 2 & 5 & 24 & 41 & 112 & 191 & 272 & 346 & 346 \\
\hline jpe & 50 & 85.80 & 216.31 & 1 & 7 & 8 & 13 & 25 & 77 & 155 & 232 & 1,491 & 1,491 \\
qje & 61 & 71.60 & 74.06 & 4 & 9 & 12 & 24 & 48 & 82 & 167 & 211 & 370 & 370 \\
restud & 28 & 39.45 & 49.50 & 4 & 5 & 8 & 10 & 20 & 48 & 109 & 111 & 230 & 230 \\
\hline All & 263 & 64.17 & 115.66 & 0 & 6 & 8 & 13 & 28 & 70 & 154 & 204 & 426 & 1,491 \\
\hline
\end{tabular}

Table 44 lists the top 25 articles with at least one JEL code R. See for a precise definition of the different variables Section 6.1. 
Table 44: Top 25 articles for $T=1991-2014$ Code $\mathrm{R}$, normalized per year

\begin{tabular}{|c|c|c|c|c|c|c|c|}
\hline$\widetilde{R}(\mathrm{R})$ & $\widetilde{C_{i}}\left(C_{i}\right)$ & Title & Authors & Journal & pct & Type & USA \\
\hline $1(1)$ & $1491(2176)$ & Increasing Returns and Economic Geography & Krugman & jpe-91 & $100 \%$ & $\mathrm{~T}$ & 1 \\
\hline $2(2)$ & $512(655)$ & R\&D spillovers and the geography of innovation an & Audretsch ; Feldman & $\operatorname{aer}(\mathrm{s})-96$ & $50 \%$ & $\mathrm{D}$ & 0.50 \\
\hline $3(3)$ & $426(611)$ & Growth in Cities & Glaeser et al. & jpe-92 & $50 \%$ & $\mathrm{D}$ & 0.25 \\
\hline $4(4)$ & $370(464)$ & Zipf's Law for Cities & Gabaix & qje-99 & $100 \%$ & $\mathrm{D}$ & 1 \\
\hline $5(11)$ & $346(218)$ & Experimental Analysis of Neighborhood Effects & Kling et al. & ecma-07 & $50 \%$ & $\mathrm{D}$ & 1 \\
\hline $6(5)$ & $337(431)$ & Productivity and the Density of Economic Activity & Ciccone ; Hall & aer-96 & $67 \%$ & $\mathrm{D}$ & 0.75 \\
\hline $7(6)$ & $310(396)$ & Company-Scientist Locational Links & Audretsch ; Stephan & $\operatorname{aer}(\mathrm{s})-96$ & $100 \%$ & $\mathrm{~T}$ & 0.50 \\
\hline $8(8)$ & $283(298)$ & Loss Aversion and Seller Behavior & Genesove ; Mayer & qje-01 & $100 \%$ & $\mathrm{D}$ & 0.50 \\
\hline $9(43)$ & $250(80)$ & The Geographic Determinants of Housing Supply & Saiz & qje-10 & $67 \%$ & $\mathrm{D}$ & 1 \\
\hline $10(7)$ & $232(333)$ & Convergence & Barro ; Sala-i-Martin & jpe-92 & $25 \%$ & $\mathrm{D}$ & 1 \\
\hline $11(13)$ & $230(194)$ & Testing for Localization Using Micro-ge & Duranton ; Overman & restud-05 & $100 \%$ & $\mathrm{D}$ & 0 \\
\hline $12(27)$ & $211(142)$ & Causes of Sprawl & Burchfield et al. & qje-06 & $100 \%$ & $\mathrm{D}$ & 0 \\
\hline $13(60)$ & $208(54)$ & The Fundamental Law of Road Congestion & Duranton ; Turner & aer-11 & $100 \%$ & $\mathrm{~T}$ & 0 \\
\hline $14(62)$ & $204(53)$ & The Area and Population of Cities & Rozenfeld et al. & $\operatorname{aer}(\mathrm{s})-11$ & $100 \%$ & $\mathrm{D}$ & 0.88 \\
\hline $15(12)$ & $202(213)$ & Moving to Opportunity in Boston & Katz et al. & qje-01 & $67 \%$ & $\mathrm{E}$ & 1 \\
\hline $16(98)$ & $202(21)$ & The Growth of Low-Skill Service Jobs and the Polar & Autor ; Dorn & aer-13 & $33 \%$ & $\mathrm{~T}$ & 0.50 \\
\hline $17(21)$ & $198(167)$ & Uncovering the Distribution of Motorists' Preferen & Small et al. & ecma(s)-05 & $100 \%$ & $\mathrm{E}$ & 0.67 \\
\hline $18(9)$ & $195(291)$ & Geographic Concentration in U.S. Manufacturing Ind & Ellison ; Glaeser & jpe-97 & $50 \%$ & $\mathrm{D}$ & 1 \\
\hline $19(16)$ & $184(185)$ & Technology, Geography, and Trade & Eaton ; Kortum & ecma-02 & $33 \%$ & $\mathrm{D}$ & 1 \\
\hline $20(23)$ & $180(158)$ & Gibrat's Law for (All) Cities & Eeckhout & aer-04 & $100 \%$ & $\mathrm{D}$ & 1 \\
\hline $21(46)$ & $175(74)$ & The Consequences of Mortgage Credit Expansion & Mian ; Sufi & qje-09 & $33 \%$ & $\mathrm{D}$ & 1 \\
\hline $22(26)$ & $173(146)$ & Urban Decline and Durable Housing & Glaeser ; Gyourko & jpe-05 & $100 \%$ & $\mathrm{~T}$ & 1 \\
\hline $23(18)$ & $171(181)$ & Nursery Cities & Duranton ; Puga & aer-01 & $67 \%$ & $\mathrm{D}$ & 0 \\
\hline $24(10)$ & $167(224)$ & Workings of a City & Benabou & qje-93 & $100 \%$ & $\mathrm{~T}$ & 1 \\
\hline $25(30)$ & $160(135)$ & House Prices, Borrowing Constraints, and Monetary & Iacoviello & aer-05 & $50 \%$ & $\mathrm{D}$ & 1 \\
\hline
\end{tabular}




\subsection{Code Q: Agricultural and Natural Resource Economics ; Environmental and Ecological Economics}

Table 45 reports the number of published articles with at least one JEL code Q, for each journal and both the full period and our five subperiods. Publications in the AER and ECMA are decomposed in regular and shorter publications. It shows that out of 6,816 articles 244 have at least one JEL code Q.

Table 45: Nb of articles with at least one JEL code Q

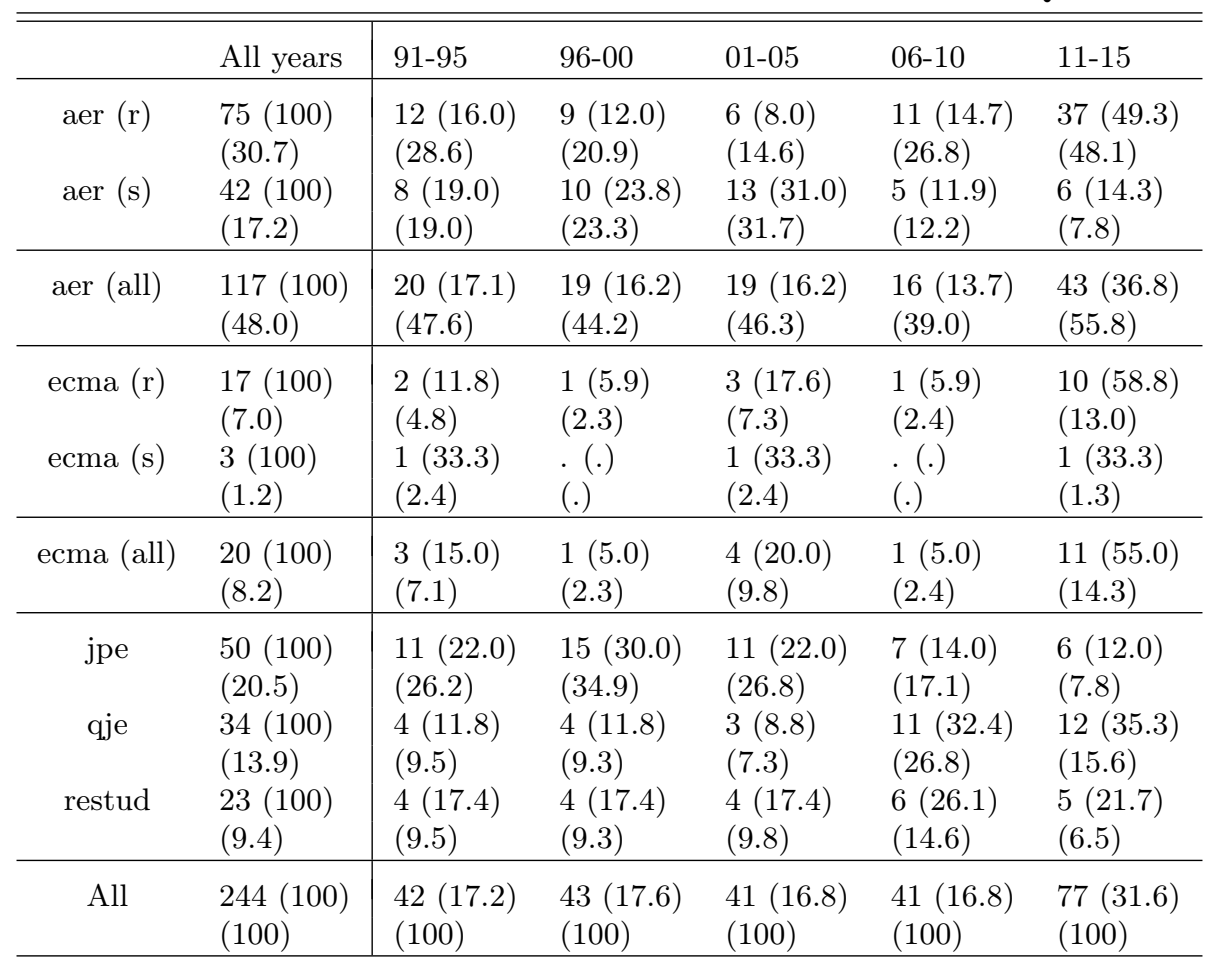

This table should be compared with Table 1. If all JEL codes were equally represented in each journal, the percentages of both tables would be the same. Code Q articles are relatively more present in AER (46.3 vs $32.9 \%$ ), JPE (21.6 vs $15.0 \%$ ) but less in ECMA (8.4 vs 21\%) and RESTUd (10.1 vs 15.7\%). Table 46 summarizes the distributions of year-normalized citations for JEL code Q per journal (year 2015 is excluded here). They should be compared to the ones of Table 9 .

Table 46: Year-normalized citations for JEL code Q

\begin{tabular}{lrrrrrrrrrrrrr}
\hline \hline & $\mathrm{N}$ & mean & $\sigma$ & min & $\mathrm{p} 5$ & $\mathrm{p} 10$ & $\mathrm{p} 25$ & $\mathrm{p} 50$ & $\mathrm{p} 75$ & $\mathrm{p} 90$ & $\mathrm{p} 95$ & $\mathrm{p} 99$ & $\mathrm{max}$ \\
\hline aer (r) & 64 & 71.48 & 76.43 & 3 & 6 & 9 & 17 & 45 & 95 & 167 & 226 & 389 & 389 \\
aer (s) & 41 & 56.47 & 78.60 & 0 & 1 & 3 & 9 & 24 & 56 & 169 & 208 & 367 & 367 \\
\hline aer (all) & 105 & 65.62 & 77.26 & 0 & 3 & 6 & 14 & 41 & 85 & 169 & 226 & 367 & 389 \\
\hline ecma (r) & 16 & 56.22 & 62.03 & 2 & 2 & 6 & 24 & 30 & 76 & 123 & 249 & 249 & 249 \\
ecma (s) & 3 & 9.41 & 3.83 & 5 & 5 & 5 & 5 & 10 & 13 & 13 & 13 & 13 & 13 \\
\hline ecma (all) & 19 & 48.83 & 59.29 & 2 & 2 & 5 & 10 & 27 & 71 & 123 & 249 & 249 & 249 \\
\hline jpe & 49 & 37.80 & 39.69 & 1 & 3 & 5 & 9 & 22 & 55 & 100 & 119 & 171 & 171 \\
qje & 31 & 51.47 & 72.82 & 2 & 3 & 11 & 19 & 36 & 56 & 76 & 125 & 415 & 415 \\
restud & 23 & 29.07 & 48.59 & 2 & 4 & 4 & 7 & 17 & 27 & 43 & 112 & 226 & 226 \\
\hline All & 227 & 52.57 & 66.92 & 0 & 3 & 5 & 13 & 28 & 66 & 131 & 184 & 367 & 415 \\
\hline
\end{tabular}

Table 47 lists the top 25 articles with at least one JEL code Q. See for a precise definition of the different 
variables Section 6.1.

Table 47: Top 25 articles for $T=1991-2014$ Code Q, normalized per year

\begin{tabular}{|c|c|c|c|c|c|c|c|}
\hline$\widetilde{\mathrm{R}}(\mathrm{R})$ & $\widetilde{C_{i}}\left(C_{i}\right)$ & Title & Authors & Journal & pct & Type & USA \\
\hline $1(1)$ & $415(512)$ & Economic Growth and the Environment & Grossman ; Krueger & qje-95 & $50 \%$ & $\mathrm{D}$ & 1 \\
\hline $2(42)$ & $389(66)$ & The Environment and Directed Technical Change & Acemoglu et al. & aer-12 & $67 \%$ & $\mathrm{~T}$ & 0.88 \\
\hline $3(14)$ & $367(156)$ & Not All Oil Price Shocks Are Alike & Kilian & $\operatorname{aer}(\mathrm{s})-09$ & $50 \%$ & $\mathrm{D}$ & 1 \\
\hline $4(2)$ & $319(437)$ & The Impact of Global Warming on Agriculture & Mendelsohn et al. & aer-94 & $100 \%$ & $\mathrm{D}$ & 0.67 \\
\hline $5(125)$ & $249(11)$ & Optimal Taxes on Fossil Fuel in General Equilibriu & Golosov et al. & ecma-14 & $57 \%$ & $\mathrm{D}$ & 0.50 \\
\hline $6(3)$ & $243(305)$ & Unbiased Value Estimates for Environmental Goods & Cummings ; Taylor & aer(s)-99 & $100 \%$ & $\mathrm{D}$ & 1 \\
\hline $7(45)$ & $243(63)$ & Nudging Farmers to Use Fertilizer & Duflo et al. & aer-11 & $100 \%$ & $\mathrm{E}$ & 0.83 \\
\hline $8(4)$ & $226(289)$ & A Regional Dynamic General-Equilibrium Model of Al & Nordhaus ; Yang & aer-96 & $100 \%$ & $\mathrm{~T}$ & 1 \\
\hline $9(101)$ & $226(23)$ & Commodity Price Shocks and Civil Conflict & Dube ; Vargas & restud-13 & $57 \%$ & $\mathrm{D}$ & 0.50 \\
\hline $10(5)$ & $208(285)$ & Environmental Levies and Distortionary Taxation & de Bovenberg ; Mooij & $\operatorname{aer}(\mathrm{s})-94$ & $100 \%$ & $\mathrm{~T}$ & 0 \\
\hline $11(6)$ & $196(242)$ & Homegrown Values and Hypothetical Surveys & Cummings et al. & $\operatorname{aer}(\mathrm{s})-95$ & $100 \%$ & $\mathrm{~T}$ & 1 \\
\hline $12(23)$ & $184(116)$ & The Economic Impacts of Climate Change & Deschenes ; Greenstone & aer-07 & $80 \%$ & $\mathrm{D}$ & 1 \\
\hline $13(47)$ & $181(58)$ & Beyond Markets and States & Ostrom & aer-10 & $25 \%$ & $\mathrm{~T}$ & 1 \\
\hline $14(8)$ & $171(211)$ & Can Markets Value Air Quality & Smith ; Huang & jpe-95 & $100 \%$ & $\mathrm{D}$ & 1 \\
\hline $15(7)$ & $169(216)$ & Optimal Environmental Taxation in the Presence of & Bovenberg; Goulder & $\operatorname{aer}(\mathrm{s})-96$ & $100 \%$ & $\mathrm{~T}$ & 0.50 \\
\hline $16(11)$ & $167(177)$ & Is Free Trade Good for the Environment & Antweiler et al. & aer-01 & $50 \%$ & $\mathrm{D}$ & 0.33 \\
\hline $17(15)$ & $152(153)$ & Induced Innovation and Energy Prices & Popp & aer-02 & $67 \%$ & $\mathrm{D}$ & 1 \\
\hline $18(10)$ & $145(178)$ & Property Rights and Investment Incentives & Besley & jpe-95 & $50 \%$ & $\mathrm{D}$ & 0 \\
\hline $19(115)$ & $135(14)$ & Identifying Supply and Demand Elasticities of Agri & Roberts ; Schlenker & aer-13 & $100 \%$ & $\mathrm{D}$ & 1 \\
\hline $20(60)$ & $134(43)$ & Learning about a New Technology & Conley ; Udry & aer-10 & $25 \%$ & $\mathrm{D}$ & 1 \\
\hline $21(9)$ & $133(191)$ & Rural Reforms and Agricultural Growth in China & Lin & aer-92 & $50 \%$ & $\mathrm{D}$ & 0 \\
\hline $22(26)$ & $132(111)$ & Will U.S. Agriculture Really Benefit from Global W & Schlenker et al. & $\operatorname{aer}(\mathrm{s})-05$ & $100 \%$ & $\mathrm{D}$ & 1 \\
\hline $23(153)$ & $131(6)$ & Knowledge Is (Less) Power & Jessoe ; Rapson & $\operatorname{aer}(\mathrm{s})-14$ & $33 \%$ & $\mathrm{E}$ & 1 \\
\hline $23(153)$ & $131(6)$ & Do Consumers Respond to Marginal or Average Price & Ito & aer-14 & $20 \%$ & $\mathrm{D}$ & 1 \\
\hline $25(63)$ & $125(40)$ & The Geographic Determinants of Housing Supply & Saiz & q.je-10 & $33 \%$ & $\mathrm{D}$ & 1 \\
\hline
\end{tabular}




\section{References}

Victoria Anauati, Sebastian Galiani, and Ramiro H Gálvez. Quantifying the life cycle of scholarly articles across fields of economic research. Economic Inquiry, 54(2):1339-1355, 2016.

David Card and Stefano DellaVigna. Nine Facts about Top Journals in Economics. Journal of Economic Literature, pages 144-161, 2013.

Glenn Ellison. Evolving Standards for Academic Publishing: A q-r Theory. Journal of Political Economy, 110(5):994-1034, 2002.

Daniel S Hamermesh. Six Decades of Top Economics Publishing: Who and How? Journal of Economic Literature, pages 162-172, 2013.

Michael A Kelly and Stephen Bruestle. Trend of subjects published in economics journals 1969-2007. Economic Inquiry, 49(3):658-673, 2011.

E. Han Kim, Adair Morse, and Luigi Zingales. What Has Mattered to Economics Since 1970. Journal of Economic Perspectives, 20(4):189-202, Fall 2006.

Thomas P Ryan and William H Woodall. The most-cited statistical papers. Journal of Applied Statistics, 32(5):461-474, 2005.

Richard Van Noorden, Brendan Maher, Regina Nuzzo, et al. The top 100 papers. Nature, 514(7524): 550-553, 2014.

\section{APPENDIX}

\section{A Types}

Table 48 shows (pooling all 5 journals) how many articles of each type have been published overall and during each time period.

Table 48: Nb of articles per type and per time period

\begin{tabular}{|c|c|c|c|c|c|c|}
\hline & All years & 91-95 & $96-00$ & 01-05 & $06-10$ & $11-15$ \\
\hline $\begin{array}{c}\text { Data } \\
(\%)\end{array}$ & $\begin{array}{l}2,865 \\
(42.0)\end{array}$ & $\begin{array}{c}473 \\
(33.6)\end{array}$ & $\begin{array}{c}460 \\
(38.5)\end{array}$ & $\begin{array}{c}586 \\
(41.5)\end{array}$ & $\begin{array}{c}608 \\
(45.5)\end{array}$ & $\begin{array}{c}738 \\
(50.5)\end{array}$ \\
\hline $\begin{array}{l}\text { Expe } \\
(\%)\end{array}$ & $\begin{array}{c}477 \\
(7.0)\end{array}$ & $\begin{array}{c}58 \\
(4.1)\end{array}$ & $\begin{array}{c}60 \\
(5.0)\end{array}$ & $\begin{array}{c}83 \\
(5.9)\end{array}$ & $\begin{array}{c}135 \\
(10.1)\end{array}$ & $\begin{array}{c}141 \\
(9.6)\end{array}$ \\
\hline $\begin{array}{l}\text { Theo } \\
(\%)\end{array}$ & $\begin{array}{l}3,474 \\
(51.0)\end{array}$ & $\begin{array}{c}877 \\
(62.3)\end{array}$ & $\begin{array}{c}676 \\
(56.5)\end{array}$ & $\begin{array}{c}744 \\
(52.7)\end{array}$ & $\begin{array}{c}594 \\
(44.4)\end{array}$ & $\begin{array}{c}583 \\
(39.9)\end{array}$ \\
\hline All & $\begin{array}{c}6,816 \\
(100.0)\end{array}$ & $\begin{array}{c}1,408 \\
(100.0)\end{array}$ & $\begin{array}{c}1,196 \\
(100.0)\end{array}$ & $\begin{array}{c}1,413 \\
(100.0)\end{array}$ & $\begin{array}{c}1,337 \\
(100.0)\end{array}$ & $\begin{array}{c}1,462 \\
(100.0)\end{array}$ \\
\hline
\end{tabular}

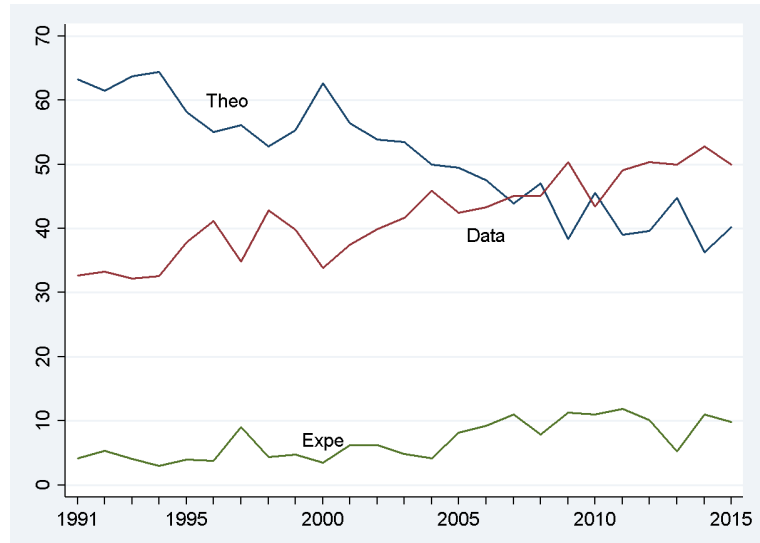

Table 49 details (pooling all years) how many articles of each type have been published in each journal. 
Table 49: Nb of articles per journal and per type (all years)

\begin{tabular}{cc|ccc}
\hline \hline & All types & Data & Expe & Theo \\
\hline aer (r) & $1,555(100 \%)$ & $667(42.9 \%)$ & $143(9.2 \%)$ & $745(47.9 \%)$ \\
aer (s) & $689(100 \%)$ & $175(25.4 \%)$ & $61(8.9 \%)$ & $453(65.7 \%)$ \\
\hline aer (all) & $2,244(100 \%)$ & $842(37.5 \%)$ & $204(9.1 \%)$ & $1,198(53.4 \%)$ \\
\hline ecma (r) & $1,078(100 \%)$ & $474(44.0 \%)$ & $99(9.2 \%)$ & $505(46.8 \%)$ \\
ecma (s) & $351(100 \%)$ & $165(47.0 \%)$ & $26(7.4 \%)$ & $160(45.6 \%)$ \\
\hline ecma (all) & $1,429(100 \%)$ & $639(44.7 \%)$ & $125(8.7 \%)$ & $665(46.5 \%)$ \\
\hline jpe & $1,021(100 \%)$ & $456(44.7 \%)$ & $36(3.5 \%)$ & $529(51.8 \%)$ \\
qje & $1,053(100 \%)$ & $558(53.0 \%)$ & $59(5.6 \%)$ & $436(41.4 \%)$ \\
restud & $1,069(100 \%)$ & $370(34.6 \%)$ & $53(5.0 \%)$ & $646(60.4 \%)$ \\
\hline All & $6,816(100 \%)$ & $2,865(42.0 \%)$ & $477(7.0 \%)$ & $3,474(51.0 \%)$ \\
\hline
\end{tabular}

